Umesh Namdeo Nehete

Synthesis, Spectral Studies, Structural Elucidation and

Magnetic Properties of Metallasiloxanes containing Main

Group and Transition Metals

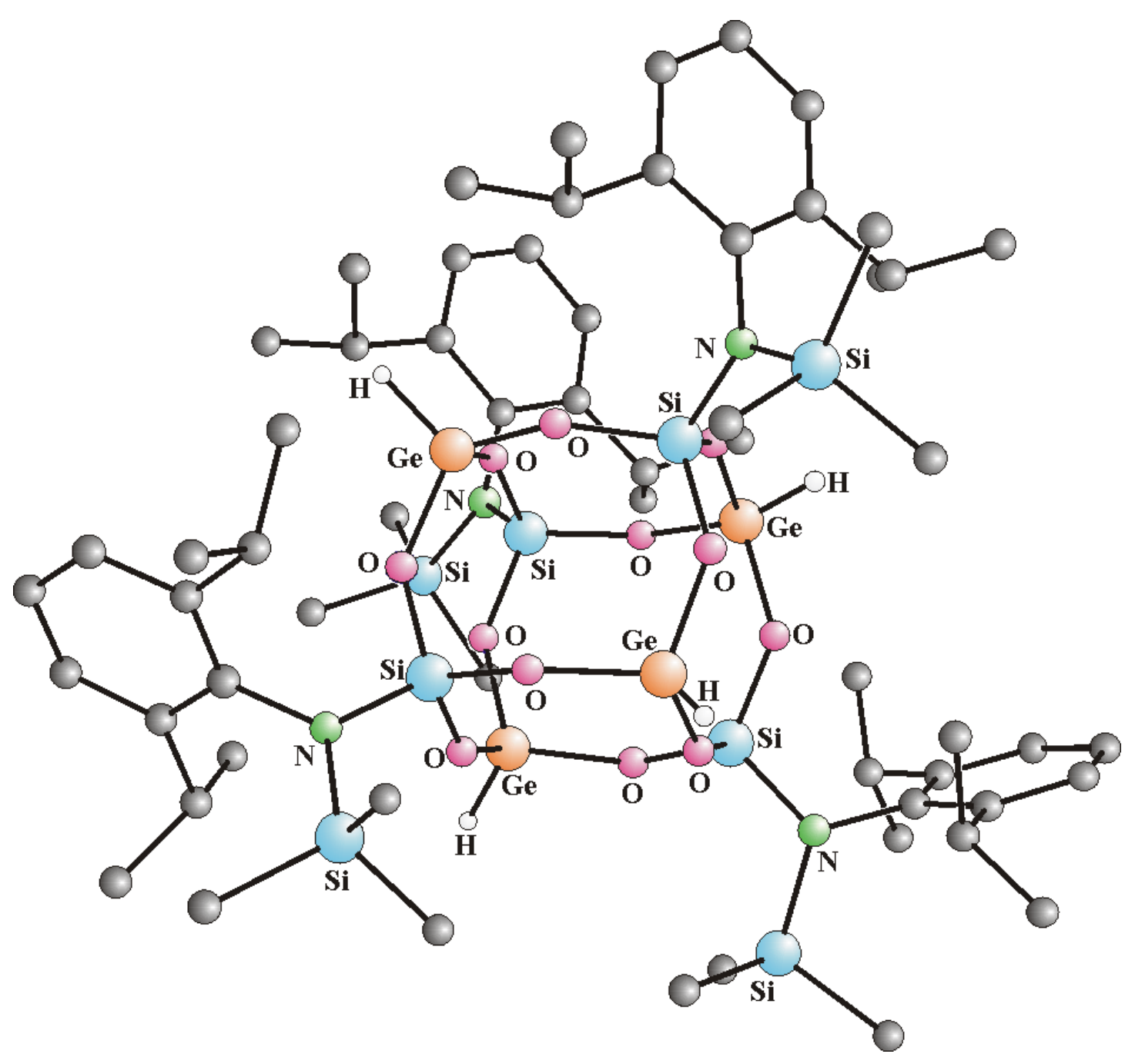


Synthesis, Spectral Studies, Structural Elucidation and Magnetic

Properties of Metallasiloxanes containing Main Group and

\title{
Transition Metals
}

\author{
Dissertation \\ zur Erlangung des Doktorgrades \\ der Mathematisch-Naturwissenschaftlichen Fakultäten \\ der Georg-August-Universität zu Göttingen
}

\author{
vorgelegt von \\ Umesh Namdeo Nehete \\ aus Jalgaon \\ (Indien)
}

Göttingen 2005 
D7

Referent:

Professor Dr. Dr. h.c. mult. H. W. Roesky

Korreferent:

Professor Dr. J. Magull

Tag der mündlichen Prüfung:

02.11.2005 


\section{Acknowledgement}

The work described in this doctoral thesis has been carried out under the guidance and supervision of Professor Dr. Dr. h.c. mult. Herbert W. Roesky at the Institute of Inorganic Chemistry of the Georg-August-University in Göttingen between April 2003 and December 2005 .

My sincere thanks to

\section{Professor Dr. Dr. h.c. mult. Herbert W. Roesky}

for his constant advice, guidance, motivation, suggestions, and discussions throughout this work. I would like to thank him for his personal attention and the freedom I enjoyed during my stay in Göttingen.

I profoundly take this opportunity in expressing my sincere thanks to Prof. Dr. R. Murugavel, Dr. Mrinalini G. Walawalkar, Prof. Dr. Vadapalli Chandrasekhar, and Dr. Ganapathi Anantharaman for teaching me the experimental skills in the initial phase of my work. I would like to thank Prof. J. Magull, Dr. D. Vidovic, Dr. M. Noltemeyer, Mr. H.-G. Schmidt, Dr. V. Jancik, and Mr. A. Pal for their help in the X-ray crystal structure investigations and their friendliness. I am very thankful to Prof. Dr. Konrad Samwer, Dr. Björn Sass, Dr. G. Leibeling and Mr. Dmitrij Bogdanov, for magnetic measurements. I thank Mr. W. Zolke, Mr. J. Schöne, Dr. G. Elter (NMR studies), Dr. D. Böhler, Mr. T. Schuchhardt (Mass Spectral measurements), Mr. Mathias Hesse, Mr. H.-J. Feine (IR Spectral measurements), Mr. J. Schimkowiak, Mr. M. Schlote, Frau H. Tappe and the staff of analytical division for their timely help.

I thank all my colleagues for creating a lively work atmosphere and for having good rapport with me. I am grateful to Dr. D. Neculai, Dr. A. M. Neculai, Dr. M. Schiefer, Dr. A. Stasch, Dr. M. Gorol, Dr. G. Bai, Dr. P. Lobinger, Dr. Jansen, Dr. N. Mösch-Zanetti, Dr. H. Zhu, Dr. Y. Peng, Dr. J. Chai, Dr. Ahn, Dr. P. Mukharji, Dr. S. Kumar, Dr. R. Oswald, Dr. C. He, Dr. C. So, Mr. L. Pineda, Mr. T. Blunck, Mr. S. Singh, Mr. S. Nembenna, Mr. G. Basvaraj, Mr. Z. Yang, Mr. Z. Zhang, and Mr. C. Ene for providing friendly work atmosphere. I gratefully acknowledge the help rendered by Dr. S. K. Pandey during the writeup. 
1.1. Silicate 1

1.2. Historical Development of Zeolites from the Perspective of Silicate Chemistry. 2

1.3. Metallasiloxanes as Model Compounds and Precursors 4

1.4. Scope and Aim of the Present Work 9

2. Contents 10

2.1. The Formal Conversion of a Proton to Hydride Using Si-OH Group and Ge(II) 10 Species Leads to the Formation of the Germanium(IV) Hydride Cluster $\left[\left(\mathrm{RSiO}_{3} \mathrm{GeH}\right)_{4}\right]\left[\mathrm{R}=\left(2,6-i \mathrm{Pr}_{2} \mathrm{C}_{6} \mathrm{H}_{3}\right) \mathrm{N}\left(\mathrm{SiMe}_{3}\right)\right]$

2.2. Molecular (SnO) $)_{6}$ Trapped by Two $\mathrm{R}_{2} \mathrm{Si}_{2} \mathrm{O}_{3}$ Fragments : X-ray Single-Crystal 16 Structure of $\left[(\mathrm{SnO})_{6}\left(\mathrm{R}_{2} \mathrm{Si}_{2} \mathrm{O}_{3}\right)_{2}\right]$

2.3. Heavy Metal Containing Polyhedral Metallasiloxane Derived from an 21 Aminosilanetriol: Synthesis and Structural Characterization of $\left[(\mathrm{PbO})_{6}\left(\mathrm{R}_{2} \mathrm{Si}_{2} \mathrm{O}_{3}\right)_{2}\right][\mathrm{R}$ $\left.=\left(2,6-i \mathrm{Pr}_{2} \mathrm{C}_{6} \mathrm{H}_{3}\right) \mathrm{N}\left(\mathrm{SiMe}_{3}\right)\right]$

2.4. Polyhedral Antimony(III), and Bismuth(III) Siloxanes: Synthesis, Spectral Studies, 27 and Structural Characterization of $\left[\mathrm{Sb}\left(\mathrm{O}_{3} \mathrm{SiR}\right)\right]_{4}$ and $\left[\mathrm{Bi}_{12}\left(\mathrm{O}_{3} \mathrm{SiR}\right)_{8}\left(\mu_{3}-\mathrm{O}\right)_{4} \mathrm{Cl}_{4}(\mathrm{THF})_{8}\right]$ $\left(\mathrm{R}=\left(2,6-i \mathrm{Pr}_{2} \mathrm{C}_{6} \mathrm{H}_{3}\right) \mathrm{N}\left(\mathrm{SiMe}_{3}\right)\right)$

2.5. First Examples of Polyhedral Ferric Siloxane

2.6. Polyhedral Cobalt(II) and Iron(II) Siloxanes: Synthesis and X-ray Crystal Structure of $\left[\left(\mathrm{RSi}(\mathrm{OH}) \mathrm{O}_{2}\right) \mathrm{Co}\left(\mathrm{OPMe}_{3}\right)\right]_{4}$ and $\left[\left(\mathrm{RSiO}_{3}\right)_{2}\left(\mathrm{RSi}(\mathrm{OH}) \mathrm{O}_{2}\right)_{4}\left(\mu_{3}-\mathrm{OH}\right)_{2} \mathrm{Fe}_{8}(\mathrm{THF})_{4}\right](\mathrm{R}=$ $\left.\left(2,6-i \mathrm{Pr}_{2} \mathrm{C}_{6} \mathrm{H}_{3}\right) \mathrm{N}\left(\mathrm{SiMe}_{3}\right)\right)$

3.1. Summary

3.2. Outlook

4. Experimental Sections

4.1. General Procedures

4.2. Physical Measurements

4.3. Starting Materials

4.4. Syntheses of Compounds 2 - 9

5. Handling and Disposal of Solvents and Residual Wastes 70

6. Crystal Data and Refinement Details

7. References 


\section{Abbreviations}

$\delta$

$\lambda$

$\mu$

$\mu_{\mathrm{B}}$

$\mu_{\text {eff }}$

$v$

$\chi$

Ar

Av

$t \mathrm{Bu}$

C

calcd.

$\mathrm{Cp}$

d

decomp.

EI

Et

eqivs.

$\mathrm{eV}$

g

$g$

G

HMDS

$\mathrm{Hz}$

$i \operatorname{Pr}$

IR

$J$

K

L

M

m

$m / z$

M.p. chemical shift

wavelength

bridging

Bohr magneton

effective magnetic moment

wave number

magnetic susceptibility

aryl

average

tert-butyl

Celsius

calculated

cyclopentadienyl

doublet

decomposition

electron impact ionization

ethyl

equivalents

electron volt

grams, gaseous

$g$-factor

Gauss

hexamethyldisilazane

Hertz

iso-propyl

infrared

coupling constant

Kelvin

ligand

metal

multiplet

mass/charge

melting point 


\begin{tabular}{ll}
$\mathrm{M}^{+}$ & molecular ion \\
Me & methyl \\
Min. & Minutes \\
MS & Mass spectrometry, mass spectra \\
NMR & Nuclear magnetic resonance \\
ppm & Parts per million \\
q & quartet \\
s & singlet \\
sept & septet \\
sh & shoulder \\
st & strong \\
$\mathrm{t}$ & triplet \\
THF & tetrahydrofuran \\
TMS & tetramethylsilane \\
$V$ & volume \\
vst & very strong \\
w & weak \\
$Z$ & number of molecules in the unit cell \\
\hline
\end{tabular}




\section{Introduction}

Humans highly depend on natural resources from the core of the earth. The limited availability of such resources has made them explore the possibilities for alternative choices that could be designed to reduce the gap between the demand for such resources and their supply. Their first attempts involved identifying resources and their role in particular functions, their categorisation and building synthetic alternatives. In order to mimic the nature, a potential approach could be identifying the natural systems as a macrocosmic collection of microscopic entities and to understand them. This can be achieved by two methods, either by dividing the natural systems into microcosmic entities, or to construct smaller building blocks for which functionalities are capable of being assembled into natural systems.

In recent years researchers are attempting to design materials that replicate natural systems. The growing importance of zeolites in contemporary life (e.g. from detergents to catalyst supports in various transformations) made a large portion of the scientific community to explore on naturally occurring minerals (metaloxides, silicates and phosphates etc.). Such a model is the subject of this dissertation as presented below.

\subsection{Silicates}

The major portion of the earth's crust is made up of silicates and silica, which constitute the bulk of all rock, soil, clay, and sands, the breakdown products of rocks. ${ }^{[1-3]}$ Approximately $30 \%$ of all minerals are silicates and some geologists estimate that about $90 \%$ of the earth's crust is made up of silicates. The basic building block of silicates is the tetrahedral silica, $\left(\mathrm{SiO}_{4}\right)$. Consisting of the small silicon ion, $\mathrm{Si}^{4+}$, surrounded by four oxygen ions, $\mathrm{O}^{2-}$, at each of the corners of a tetrahedron. ${ }^{[4]}$ The four negative charges on the whole moiety, which means that each of the oxygen ions carries a net negative charge of one. The charge can be balanced by sharing oxygen ion in two adjacent tetrahedra, leading the net zero charge. Then no further balancing is necessary. On the other hand, if the oxygen is not shared, the negative 
charge will be balanced by a metal ion. The presence of a metal atom in the siloxane framework not only makes these compounds thermally stable but also improves their catalytic and conducting properties. The complicated structures that these silicates form is truly amazing as they can form single units, double units, chains, sheets, rings and framework structures. ${ }^{[1-3]}$

\subsection{Historical Development of Zeolites from the Perspective of Silicate}

\section{Chemistry}

In 1756, the Swedish mineralogist Axel Fredrick Cronstedt observed that certain mineral crystals appeared to melt and boil at the same time when heated. ${ }^{[5]}$ Therefore, he coined the word "zeolite" a greek word that denotes "boiling stone". These zeolites are the minerals that are today termed as "molecular sieves". In 1840, Damour observed that crystals of zeolites could be reversibly dehydrated without any apparent change in their morphology. Subsequently, Grandjean in 1909, demonstrated that dehydrated zeolites absorb small molecules such as hydrogen, ammonia, $\mathrm{H}_{2} \mathrm{~S}$ and iodine. ${ }^{[6]}$ In 1925 , Weigel and Steinhoff observed that dehydrated zeolites, chabazite $\left(\mathrm{CaAl}_{2} \mathrm{Si}_{4} \mathrm{O}_{12}\right)$ would adsorb small organic molecules such as methanol, ethanol, and formic acid but reject larger ones such as benzene, ether, and acetone. ${ }^{[7]}$ After these discoveries, McBain (1932) recognized that activated or dehydrated chabazite has the property of functioning as a sieve on a molecular scale, only adsorbing molecules with less than certain critical dimensions. Thus he uses words "molecular sieving" to describe this selective absorption phenomenon. ${ }^{[4]}$ As a direct result of these studies, scientists of the Linde Company, a Division of Union Carbide Corporation, became interested in the applications of natural zeolites to gas separation operations. However, the availability of natural zeolites was inadequate for large scale commercial applications. Hence, in the early 1950's, the Linde team synthesized the first man-made zeolites, Linde A and X, via hydrothermal routes and Linde X was found isostructural with the naturally occurring mineral faujasite ${ }^{[8]}$ Further studies on zeolites were extended for their 
applications as in exchangers, gas sorption matrices and stereo selective catalysts. ${ }^{[9-12]}$ Today, one of the most industrially important uses of zeolites is in chemical catalysis, most notably in the petrochemical industries where zeolites are used in oil refining as cracking catalysts and in catalytic conversion process methanol to gasoline. ${ }^{[13]}$ It is therefore essential to fully understand the chemistry taking place to be able to accurately model these systems.

In former time, the zeolites were confined to aluminasilicates with the general formula $\mathrm{M}_{\mathrm{x} / \mathrm{n}}\left[\left(\mathrm{AlO}_{2}\right)_{\mathrm{x}}\left(\mathrm{SiO}_{2}\right)_{\mathrm{y}}\right] \cdot \mathrm{mH}_{2} \mathrm{O}$, where cations $\mathrm{M}$ of valance $n$ neutralise the negative charges in the aluminasilicate framework. Zeolites are microporous crystalline materials in which the metal atoms (silicon or aluminum) are surrounded by four oxygen anions to form an approximate tetrahedron. These tetrahedral units join together to form several different ring and cage structures. ${ }^{[14-17]}$ Since silicon typically exists in a +IV oxidation state, the siliconoxygen tetrahedra are electrically neutral. In contrast, aluminum typically exists in the + III oxidation state, which makes the zeolite frameworks anionic, hence a cation is required to maintain the charge neutrality. If the cation is $\mathrm{H}^{+}$, a bridged hydroxyl group, $\mathrm{Si}-(\mathrm{OH})-\mathrm{Al}$, is formed, which behaved as a classic Brønsted proton donating acid site. ${ }^{[18]}$ If the charge compensating cation is a relatively "soft" cation such as sodium, zeolites are excellent water softener because they can pick up the "hard" magnesium and calcium cations in water leaving behind the soft cation.

One example of zeolite is ZSM-5 (Mobil Synthetic Zeolite-5) that contains two sets of perpendicular intersecting channels, one defined by ten-membered rings and the other by eitht-membered rings. ZSM-5 was first synthesised in 1972, with high Al contents ( $\mathrm{Si} / \mathrm{Al}$ ratio lies from 20 to infinity), by hydrothermal route in the presence of tertaalkylammonium salts. ${ }^{[19]}$ The research was further developed by Argaure and Landot in $1972 .{ }^{[20,21]}$ In the later report, it was shown that the $\mathrm{Al}$ free ZSM-5 can also be synthesized. ${ }^{[22,23]}$ As the isoelectronic cations $\left(\mathrm{Al}^{3+}\right.$ and $\left.\mathrm{Si}^{4+}\right)$ can enter into the zeolite framework during the synthesis, the classical 
aluminasilicate framework can be modified by isomorphic substitution of aluminum or silicon by three- or four- coordinated heteroatoms or metals.

As discussed above, the synthesis and specific catalytic activity of zeolites have been well established. However, the factors controlling the mechanism of the crystallisation of zeolites have not yet been fully understood. ${ }^{[24-28]}$ In case of hetero-metal incorporated zeolites, the exact location of the metal ion is difficult to determine. ${ }^{[29,30]}$ Thus, the understanding of the catalytic centers, the intermediates, and the coordination geometry of the catalytic active site are not clearly understood. This makes it necessary to synthesize suitable model compounds that can either mimic the geometry of the building blocks in zeolites or have the presence of catalytic centers that are essential for a particular transformation.

\subsection{Metallasiloxanes as Model Compounds and Precursors}

Recently, there has been intense interest in the synthesis of advanced materials from the single source molecular precursor. ${ }^{[31-36]}$ The method has been used for synthesising the metal oxide precursors through the respective metal alkoxides using solution-sol-gel method. ${ }^{[37-42]}$ The primary task would be then to rationalise the formation of these materials with respect to the molecular level control and to the synthesis of new materials with tailored properties. In addition, the preparation of compounds containing three-dimensional structures has given an insight into the atomic level control of the final materials by this method. ${ }^{[31-36,43-}$ 47] This leads to the homogeneity and the desired composition of the resulting materials. Recently, this idea has been extended for the preparation of metal silicate and phosphate systems due to their wide range of applications in materials science and catalysis. 
<smiles>[R][Si]([R])([R])O</smiles>

Monosilanol<smiles>[R][Si]([R])(O)O</smiles>

Silanediol<smiles>[R][Si](O)(O)O</smiles>

Silanetriol<smiles>[R][Si](O)(O)O[Si]([R])(O)O</smiles>

Tetrahydroxydisiloxane<smiles>[R][Si]([R])(O)O[Si]([R])([R])O</smiles>

Dihydroxydisiloxane (Disilanol)<smiles>[R][Si]1([R])O[Si]2([R])O[Si]([R])(O)O[Si]([R])(O)O[Si]([R])(O)O[Si]([R])(O1)O[Si]([R])(O)O2</smiles>

\section{Silasesquioxane based silanols}

Chart 1

Silanols are compounds containing $\mathrm{Si}-\mathrm{OH}$ bonds and are considered to be analogues of alcohols. ${ }^{[1]}$ The Si-OH group containing compounds, that can be prepared in the laboratory, may be classified into three major groups. The first group of compounds contains one or more Si-OH units. Compounds containing one or more $\left[\mathrm{Si}(\mathrm{OH})_{2}\right]$ units are classified as second group, and the third group of compounds is the one that contains one or more $\left[\mathrm{Si}(\mathrm{OH})_{3}\right]$ units. The terms such as silanetriols and silanediols are used to denote compounds that possess three and two hydroxyl groups on the same silicon center. Mono-, di-, and trisilanols are used to denote compounds containing one, two and three $-\mathrm{Si}(\mathrm{OH})$ groups, respectively. Other trivial names are also used such as siloxane diols, silsequioxane silanols, etc. (Chart 1). ${ }^{[48-49]}$ 
The presence of organic moiety ' $R$ ' ( $R$ can be any alkyl, aryl or alkoxy substituent) attached to the silicon atom is necessary to impart the desired stability to the silanols. ${ }^{[48,50-52]}$ Most of these silanols have been used as starting materials to prepare a variety of metallasiloxanes. ${ }^{[53-58]}$ As pointed out earlier, the Si-O-M linkages are the basic structural units present in the naturally occurring silicate minerals in the earth's crust and in the synthetic zeolites. The type of the Si-O linkages predominantly determines the structure of these minerals and the nature of the metal atoms; they can form cyclic, chain, and sheet type structures or three dimensional frameworks as in zeolites. ${ }^{[59]}$ The soluble metallasiloxanes, which are formally derived from silanols, have shown to be structural model compounds for open-framework silicates, heterogeneous catalytic systems, and also potential precursors for mixed metal oxide systems. ${ }^{[54-58,60-67]}$

The synthesis of metallasiloxanes dates back to the end of the nineteenth century. ${ }^{[68]}$ The metallasiloxanes derived from monosilanols have been well documented. Unfortunately, silanols containing a single $-\mathrm{OH}$ functionality give rise to the monometallic product, $\left[\mathrm{M}\left(\mathrm{OSiR}_{3}\right)_{\mathrm{x}}\right]_{\mathrm{n}},{ }^{[33,69-71]}$ and cannot be an ideal catalysts, as most of the catalytic reactions are supported by more than one metal center. However, to overcome this problem, one has to use silanols bearing more than one hydroxyl group on the silicon atom in order to generate the metallasiloxane framework with two- and three-dimensional cores. The reactions of silanediols and disilanols with metal precursor yielded acyclic, cyclic and polymeric units of the resulting metallasiloxanes with different ring sizes and chain lengths. ${ }^{[55-57,71-73]}$ It has also been realized that the metallasiloxane obtained from silanetriols or incompletely condensed silsesquioxanes, (e.g., trisilanols with transition metal complexes) are generally regarded as 'realistic' model compounds as they exhibited the most advanced structural similarity with metal-modified silica surfaces. ${ }^{[60]}$

The concept of studying polyhedral metallasilsesquioxanes to mimic surface sites in heterogeneous silica-supported transition metal catalysts was first proposed by Feher et 
$a l .{ }^{[74,75]}$ Although the trisilanol approach has been quite successful in generating many types of metallasiloxanes, its limitation in most of the cases is that the $\mathrm{Si} / \mathrm{M}$ ratio is quite low. An alternative approach would be needed in order to generate metallasiloxanes with a higher $\mathrm{Si} / \mathrm{M}$ ratio as well as to vary the structures of such derivatives. In view of their applications of generating soluble metallasiloxanes with diverse structures, we will elaborate on the concept of the utility of silanetriols $\mathrm{RSi}(\mathrm{OH})_{3}$, which contain three reactive hydroxyl groups attached to one silicon center. Silanols are also quite reactive and prone to condensation reactions to generate compounds with the Si-O-Si bond by the loss of a water molecule. However, we and others have shown that it is possible to stabilize the highly reactive silanetriols by the choice of appropriate sterically hindered organic substituents. ${ }^{[55,64]}$ Initial reaction with the tert-butyl silanetriol with rhenium oxide afforded an eight-membered siloxane ring. ${ }^{[76]}$ Roesky et al. have prepared a series of stable aminosilanetriols by incorporating bulky organic groups on the aromatic ring. These silanetriols contain an additional trimethylsilyl moiety bound to nitrogen to prevent self-condensation reaction. Silanetriols have been extensively used to generate a variety of three-dimensional cage structures ${ }^{[58,64-66]}$ for example, the core structures of neutral and anionic aluminasiloxanes, either from aminosilanetriols or a cobalt cluster substituted silanetriol resembling the SBU's of zeolites. ${ }^{[77,78]}$ In order to test the utility of these metallasiloxanes in catalytic conversion, hydroformylation reactions of 1-hexene to heptanal have been carried out at $120{ }^{\circ} \mathrm{C}$ under a $\mathrm{H}_{2} / \mathrm{CO}$ at pressure of 70 bar using the cobalt cluster substituted group 13 metallasiloxanes as catalysts. The results indicated that the catalytic properties of these compounds decrease within the series of aluminum to indium siloxanes owing to the decrease in Lewis acidity of these metal atoms. ${ }^{[78]}$

An extension of these studies is due to the preparation of compounds of group 4, 5, 12 and 14 metallasiloxane cage structures. ${ }^{[58,79-85]}$ One important example is the stable cubic titanasiloxane containing peroxo groups attached to titanium, which is a key intermediate peroxo species involved in epoxidation reactions of olefins. Scheme 1 describes the 
substitution of the alkoxy group on titanium in cubic titanasilaxane followed by treatment with tert-butyl hydrogen peroxide. ${ }^{[86,87]}$

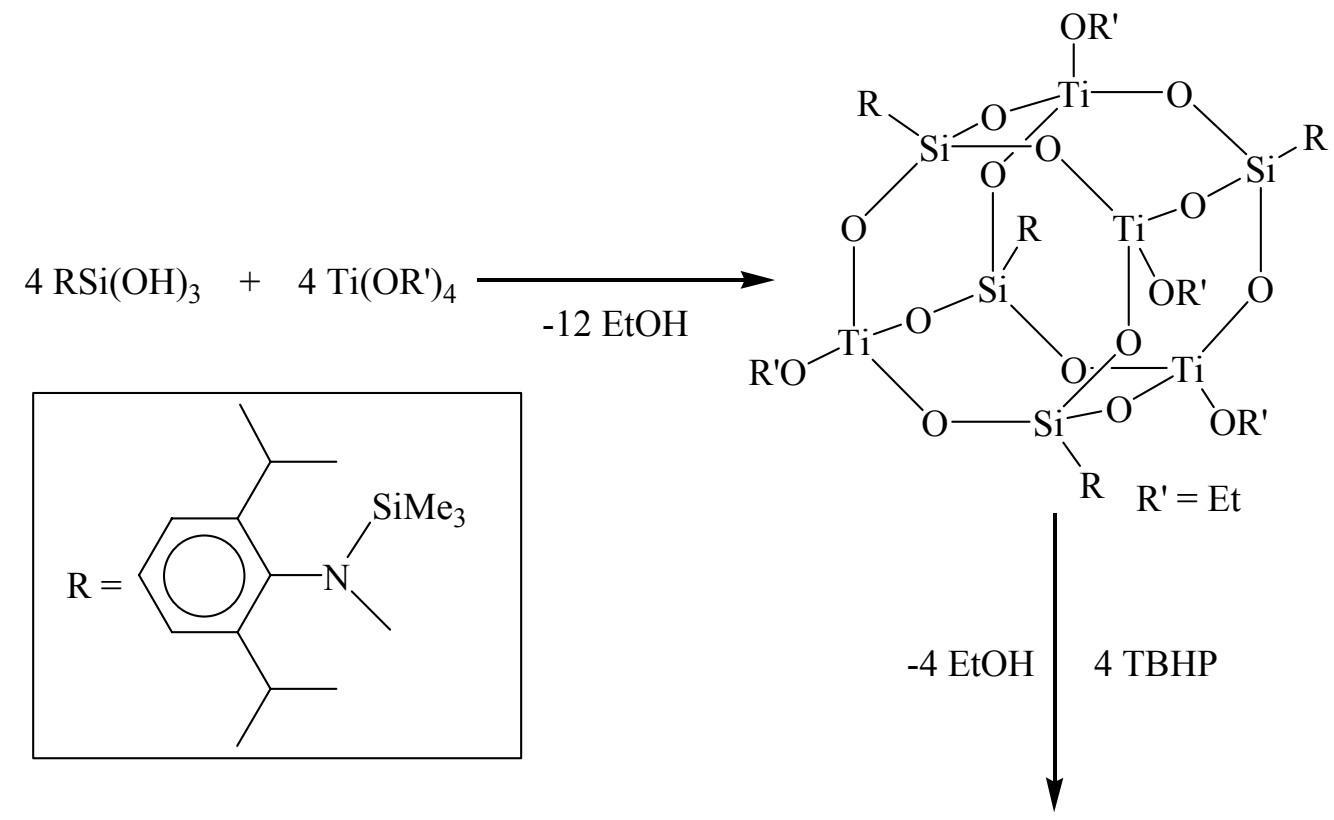

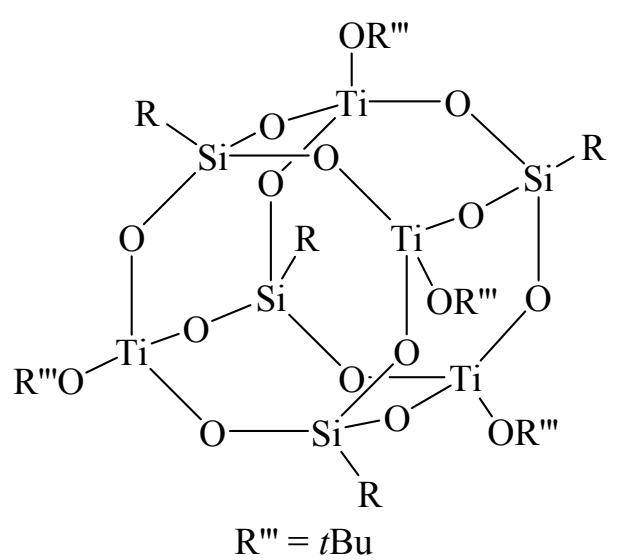<smiles>[R]O[Si]12O[Si]3([R])O[Si]4([R])O[Si]5([R7])O[Si]([R])(O3)O[Si]([R7])(O[Si]([R7])(O5)O[Si]([R])(O4)O1)O2</smiles>

Scheme 1 


\subsection{Scope and Aim of the Present Work}

Based on the previous work, described in the introduction it is clear that the studies on metallasiloxanes contribute a promising future for both scientific and industrial research. Since the structures of metallasiloxanes are analogous to modified silica surfaces, they are considered to mimic the role as catalysts. Hence they are quite valuable in understanding the mechanism of several catalytic processes, particularly those involving silica supported transition metal catalysts. ${ }^{[86,87]}$ Metallasiloxanes have also been envisioned as single-source precursors for modified zeolites. ${ }^{[58]}$ However, there have only been a few attempts to prepare soluble model compounds for metallasiloxanes of the elements of group 8, 9, 14 and 15.

The present research work was undertaken with the following objectives:

- to investigate innovative methodology and facile synthesis of metallasiloxanes by conducting metathesis reactions of silanetriol with metal amides.

- to synthesize and characterize the soluble metallasiloxanes of group 14 and 15 elements in order to find their applications as precursor for respective metal silicates.

- to synthesize soluble metallasiloxanes of group 8 and 9 elements, which might serve as prototype naturally occurring metal silicates of these elements.

- to explore the catalytic activity of newly synthesized compounds in order to understand their mechanistic aspects.

- to investigate different bonding models of metallasiloxanes by single crystal X-ray diffraction analyses.

- to study the magnetic properties of the metallasiloxanes of group 8 and 9 elements by using temperature dependent magnetic susceptibility measurements. 


\section{Contents}

\subsection{The Formal Conversion of a Proton to Hydride Using Si-OH Group and Ge(II) Species Leads to the Formation of the Germanium(IV) Hydride Cluster $\left[\left(\mathrm{RSiO}_{3} \mathrm{GeH}\right)_{4}\right]$}

Metallasiloxanes derived from silanetriol are of considerable interest in academic, because of versatile structural aspects. ${ }^{[53]}$ Utilizing the multi-functional N-bonded silanetriol, $\mathrm{RSi}(\mathrm{OH})_{3}\left[\mathrm{R}=\left(2,6-i \mathrm{Pr}_{2} \mathrm{C}_{6} \mathrm{H}_{3}\right) \mathrm{N}\left(\mathrm{SiMe}_{3}\right)\right](\mathbf{1})$, we have successfully assembled a number of polyhedral metallosiloxanes with a high metal/silicon ratio. ${ }^{[58,64,67]}$ Different structural properties and compositions provide an arena for their reactivities in the field of catalyst and material sciences. To our experience in the synthesis of soluble metal silicates, it seems to be a challenge to synthesize a soluble molecular germanium(II) siloxane. Only a handful of structurally characterized compounds containing the Ge-O-Si linkage have been reported so far, for instance $\left\{\left[\left(\mathrm{Ph}_{2} \mathrm{Ge}\right)_{2}\left(\mathrm{Ph}_{2} \mathrm{Si}\right)_{2} \mathrm{O}_{4}\right],{ }^{[88]}\left[\left(\mathrm{Me}_{2} \mathrm{Ge}\right)_{2}\left(\mathrm{Ph}_{2} \mathrm{Si}\right)_{2} \mathrm{O}_{4}\right],{ }^{[88]}\left[\left(\mathrm{Cl}_{2} \mathrm{Ge}\right)_{2}(t \mathrm{BuSi})_{2} \mathrm{O}_{4}\right],{ }^{[89]}\right.$ $\left[\left(\mathrm{Et}_{2} \mathrm{Ge}\right)_{2}\left(\mathrm{Ph}_{2} \mathrm{Si}\right)_{2} \mathrm{O}_{4}\right],{ }^{[90]}$ $\left[\left(\mathrm{Ph}_{2} \mathrm{Ge}\right)_{2}\left(\mathrm{Ph}_{2} \mathrm{Si}\right)_{2} \mathrm{O}_{3}\right],{ }^{[91]}$ $\left.\left[\left(t \mathrm{Bu}_{2} \mathrm{Ge}\right)\left(\mathrm{Ph}_{2} \mathrm{Si}\right)\left\{\left(\left(\mathrm{CH}_{2}\right)_{3} \mathrm{NMe}_{2}\right)_{2} \mathrm{Sn}\right\} \mathrm{O}_{3}\right]^{[92]}\right\}$. Herein, we report the first polyhedral germanium siloxane $\left[\mathrm{RSiO}_{3} \mathrm{GeH}\right]_{4}\left[\mathrm{R}=\left(2,6-i \mathrm{Pr}_{2} \mathrm{C}_{6} \mathrm{H}_{3}\right) \mathrm{N}\left(\mathrm{SiMe}_{3}\right)\right]$ (2). This species also is the first example of a Ge-O-Si containing compound exhibiting terminal functional $\mathrm{Ge}-\mathrm{H}$ units. Although compounds of the type of Group $14,\left[\mathrm{HSiO}_{3}\right]_{4}$ are known, ${ }^{[93]}$ the corresponding germanium or germanium siloxane analogues have not been reported. The synthesis of $\left[\mathrm{RSiO}_{3} \mathrm{GeH}\right]_{4}$ also involves an unprecedented oxidative addition of a Si-O-H bond to a $\mathrm{Ge}(\mathrm{II})$ center, which leads to the formal conversion of proton to hydride. Even though, the oxidative addition of an alcohol to the alkylgermanium(II) compound is known. ${ }^{\text {94] }}$

The reaction of the germanium(II) amide ${ }^{[95]} \mathrm{Ge}\left[\mathrm{N}\left(\mathrm{SiMe}_{3}\right)_{2}\right]_{2}$ with $\mathrm{RSi}(\mathrm{OH})_{3}{ }^{[79]}$ in a $1: 1$ molar ratio afforded $\left[\mathrm{RSiO}_{3} \mathrm{GeH}\right]_{4}(2)$ in about $64 \%$ yield (Scheme 2). 


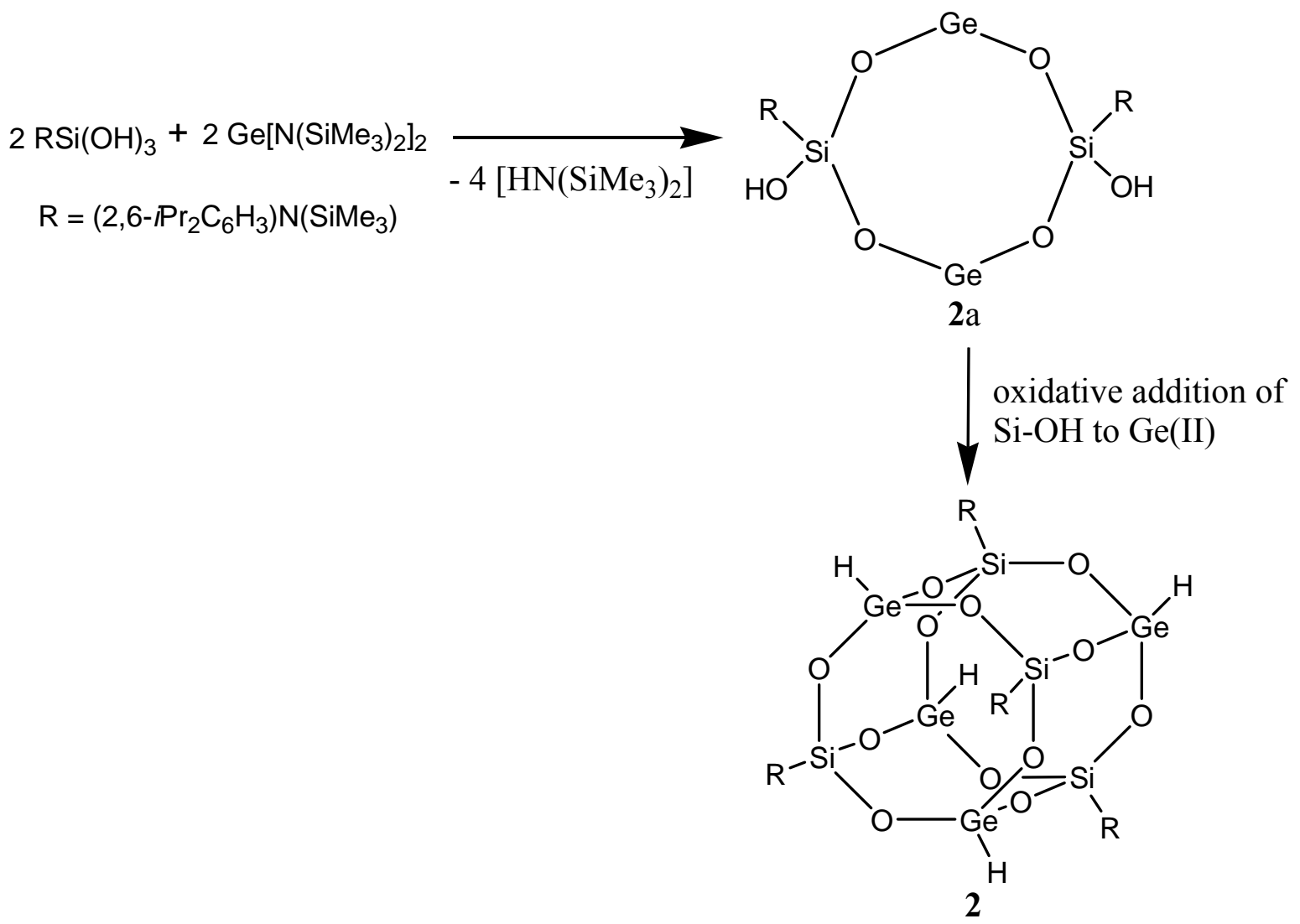

Scheme 2

The colorless crystals of $\mathbf{2}$ were obtained at room temperature from its saturated solution in hexane. Compound $\mathbf{2}$ is soluble in a large number of common organic solvents including hydrocarbons such as hexane and pentane. Compound $\mathbf{2}$ has been characterized by analytical, spectroscopic and X-ray crystallographic techniques. Thus, $\mathbf{2}$ is thermally quite stable and is also stable under the conditions of the EI mass spectrometry. The EI-mass spectrum of 2 shows the molecular ion peak at $1592.5(100 \%)\left[M^{+}\right]($Figure 1). 

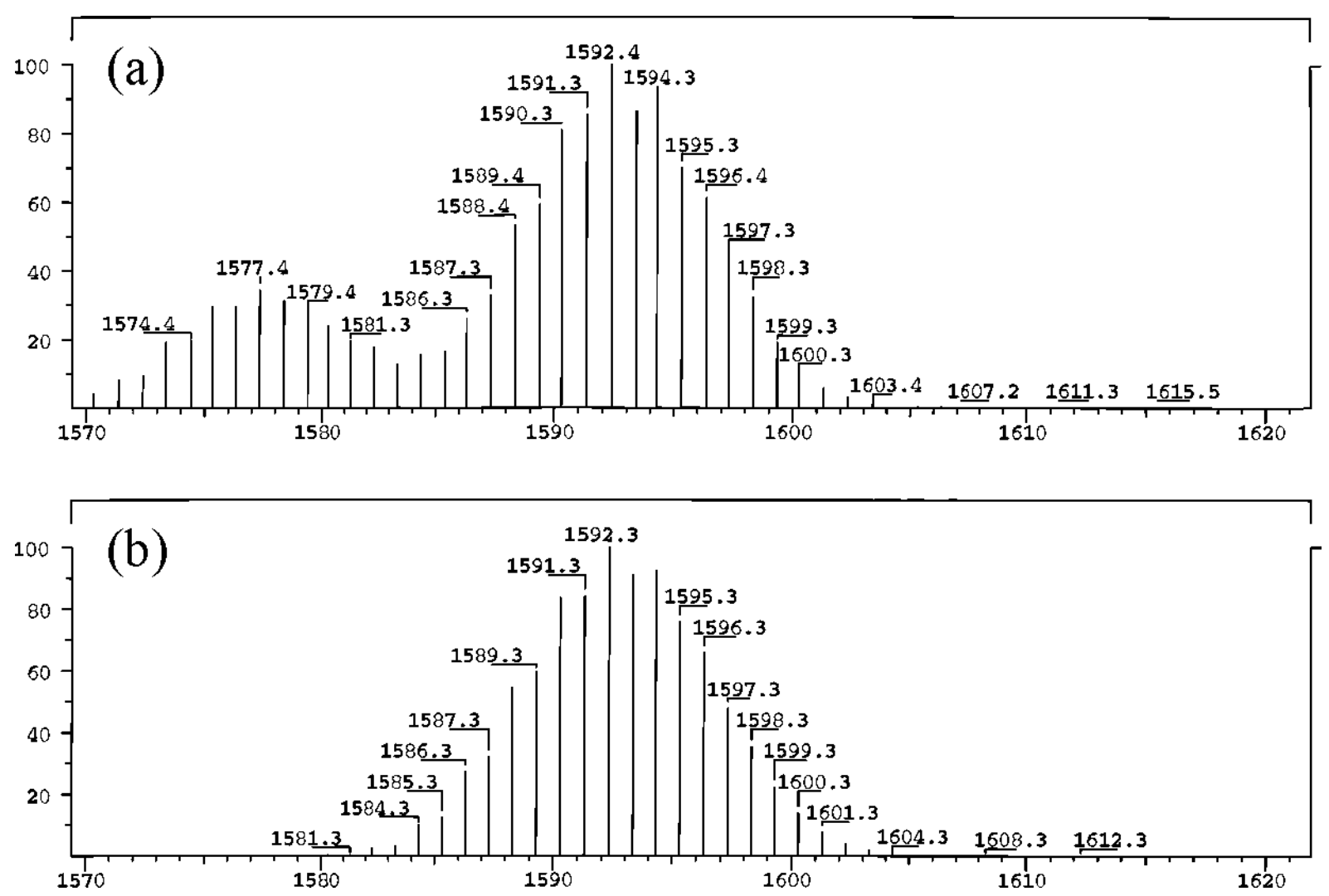

Figure 1. (a) A partial mass spectrum (electron impact) of 2 showing the parent ion in the $\mathrm{m} / \mathrm{z}$ 1583 to 1601 range. (b) A simulated isotope cluster pattern expected for the $\mathrm{C}_{60} \mathrm{H}_{108} \mathrm{Ge}_{4} \mathrm{~N}_{4} \mathrm{O}_{12} \mathrm{Si}_{8}$ composition.

The presence of the Ge-H motif is also detected in the ${ }^{1} \mathrm{H}$ NMR as a singlet that is observed at $(\delta 5.83 \mathrm{ppm}) .{ }^{[96-98]}$ The ${ }^{29} \mathrm{Si}$ NMR shows a single resonance $(\delta-87.4 \mathrm{ppm})$ for the core of $\mathbf{2}$ indicating the equivalence of the Si atoms, while the IR spectrum exhibits the characteristic Ge-H stretching frequency $\left(\widetilde{v} 2211,2184 \mathrm{~cm}^{-1}\right) \cdot{ }^{[96-98]}$ The formation of 2 involves the oxidation of Ge(II) to Ge(IV). We assume that the first step of the reaction involves the intermediate $\left[\mathrm{RSi}(\mathrm{OH}) \mathrm{O}_{2} \mathrm{Ge}\right]_{2}(2 \mathrm{a})$ which can result from a condensation of the germanium amide with the silanetriol. The next step is the fusion of two molecules of $2 \mathrm{a}$ through an intermolecular oxidative addition reaction of Si-OH with $\mathrm{Ge}(\mathrm{II})$ centers. Such a process leads to a concomitant Ge-O-Si bond formation. Alternatively it may be possible that first an oxidative addition occurs which undergoes an elimination of $\mathrm{H}\left[\mathrm{N}\left(\mathrm{SiMe}_{3}\right)_{2}\right]$, resulting in the formation of $\mathbf{2}$. Although oxidative addition reactions are ubiquitous in organometallic 
chemistry, we have found no precedence for an oxidative addition reaction involving the Si$\mathrm{OH}$ group. Moreover, during the course of this reaction the proton of the Si-OH group is formally converted to a hydride.

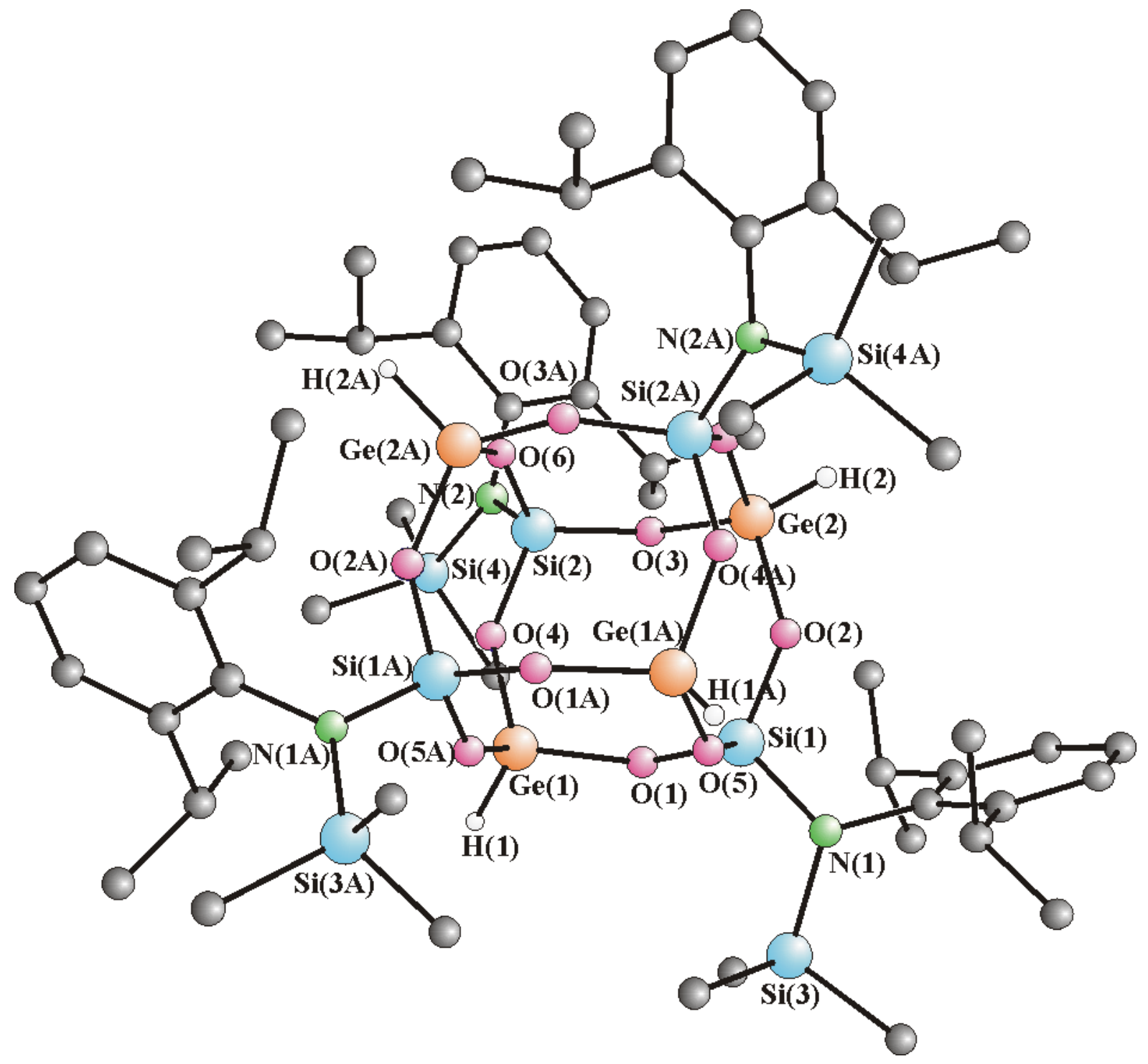

Figure 2. Molecular structure of $\mathbf{2}$ in the crystal.

Compound 2 crystallizes in the monoclinic space group $C 2 / c$. The molecular structure of $\mathbf{2}$ is shown in Figure 2. The core structure of $\mathbf{2}$ along with selected metric parameters are summarized in Figure 3. 


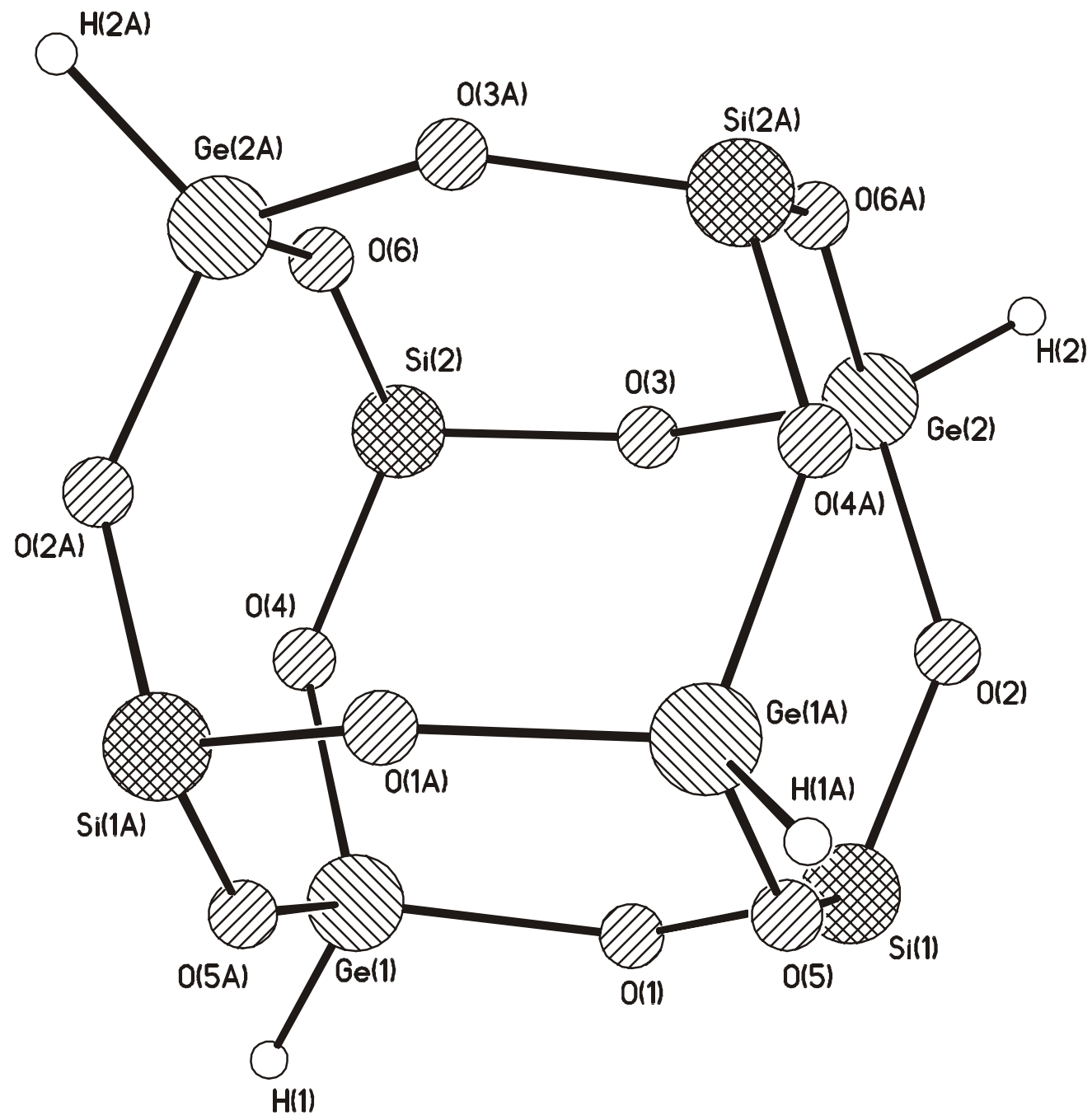

Figure 3. Core structure of 2. The substituents on silicon have been omitted for the sake of clarity. Selected bond lengths $[\AA]$ and angles $\left[^{\circ}\right]$ : $\mathrm{Ge}(1)-\mathrm{O}(5 \mathrm{~A})$ 1.737(1), $\mathrm{Ge}(2)-\mathrm{O}(6 \mathrm{~A})$ 1.738(1), Ge(1)-O(1) 1.740(1), Ge(2)-O(2) 1.745(1), Ge(1)-O(4) 1.741(1), Ge(2)-O(3) 1.742(1), Ge(1)-H(1) 1:40(2), Ge(2)-H(2) 1.38(2), Si(2)-O(6) 1.623(1), Si(2)-O(4) 1.623(2), $\mathrm{Si}(2)-\mathrm{O}(3)$ 1.628(1), Si(1)-O(2) 1.620(2), Si(1)-O(5) 1.628(2), Si(1)-O(1) 1.628(1); $\mathrm{Si}(2)-$ O(4)-Ge(1) 142.78(9), Si(1)-O(5)-Ge(1A) 142.55(10), Si(1)-O(1)-Ge(1) 140.74(9), Si(1)$\mathrm{O}(2)-\mathrm{Ge}(2)$ 142.52(9), $\mathrm{Si}(2)-\mathrm{O}(3)-\mathrm{Ge}(2)$ 140.05(9), Si(2)-O(6)-Ge(2A) 142.55(9).

The structure of $\mathbf{2}$ can be described as a polyhedral cubic cage where the alternate corners of the cube are occupied by germanium and silicon atoms. The edges of the cube contain oxygens which act as bridging atoms between germanium and silicon. Each of the six- 
faces of the cube is made up of a puckered eight-membered $\mathrm{Ge}_{2} \mathrm{O}_{4} \mathrm{Si}_{2}$ ring. The average bond distances in 2 are Ge-O [1.7405 $\AA]$, Si-O [1.625 $\AA]$ and Ge-H [1.39 $\AA]$. The Ge-O-Si bond angle [av. $141.86^{\circ}$ ] indicates the bent nature of this bond. It is interesting to compare the metric parameters observed in $\mathbf{2}$ with literature precedents. In the eight-membered rings $\left[\left(\mathrm{Me}_{2} \mathrm{Ge}\right)_{2}\left(\mathrm{Ph}_{2} \mathrm{Si}_{2}\right)_{4}\right],{ }^{[88]}\left[\left(\mathrm{Cl}_{2} \mathrm{Ge}\right)_{2}(t \mathrm{BuSi})_{2} \mathrm{O}_{4}\right],{ }^{[89]}$ and $\left[\left(\mathrm{Et}_{2} \mathrm{Ge}\right)_{2}\left(\mathrm{Ph}_{2} \mathrm{Si}\right)_{2} \mathrm{O}_{4}\right],{ }^{[90]}$ the Ge-O and Si-O distances are $[1.77(6) \AA] ;[1.60(7) \AA], \quad[1.69(4) \AA] ;[1.63(4) \AA]$, and [1.75(5) $\AA]$; $\left[\begin{array}{ll}1.61(6) & \AA\end{array}\right]$ respectively. The Ge-O-Si bond angles observed for these compounds are $\left[136.9(3)^{\circ}\right],\left[158.8(2)^{\circ}\right]$ and $\left[142.0(3)^{\circ}\right]$. These metric parameters compare well with those observed for $\mathbf{2}$. The Ge-H bond length in $\mathbf{2}[1.39(2) \AA]$ can be compared with that observed in $p$-anisylgermane $[1.40 \AA]$ reported by Schmidbaur et al. ${ }^{[96]}$

In brief, we have prepared the first cubic polyhedral cage compound that contains GeO-Si linkages. The formation of this compound occured by an unprecedented oxidative addition reaction involving the $\mathrm{Si}-\mathrm{OH}$ motif to a $\mathrm{Ge}(\mathrm{II})$ center. 


\subsection{Molecular (SnO) $)_{6}$ Trapped by $\mathrm{Two} \mathrm{R}_{2} \mathrm{Si}_{2} \mathrm{O}_{3}$ Fragments : X-Ray Single- \\ Crystal Structure of $\left[(\mathrm{SnO})_{6}\left(\mathrm{R}_{2} \mathrm{Si}_{2} \mathrm{O}_{3}\right)_{2}\right]\left[\mathrm{R}=\left(2,6-i \mathrm{Pr}_{2} \mathrm{C}_{6} \mathrm{H}_{3}\right) \mathrm{N}\left(\mathrm{SiMe}_{3}\right)\right]$}

We have a long standing interest in the design and synthesis of molecular assemblies containing the $\mathrm{Si}-\mathrm{O}-\mathrm{M}$ motif. ${ }^{[58,64,67]}$ This is motivated, in part, due to the possibility of these soluble metallasiloxanes functioning as structural models for the more complex naturally occurring metallasilicates or synthetic metal-modified zeolites. ${ }^{[77,84]}$ Another reason for our interest stems from the opportunity provided by molecular metallasiloxane structural frame works for incorporating basic structural motifs of inorganic oxides as part of the larger cage or ring structures. ${ }^{[99]}$ Such systems can be viewed as organic soluble solids containing the inorganic oxide core enveloped by a sheath of lipophilic organic exterior. ${ }^{[99]}$ Although tin(II)alkoxide cage structures have been known for some time there is a relative paucity of the corresponding tin(II) siloxane cages. ${ }^{[100-109]}$ In contrast molecular stannasiloxanes containing tin(IV) have been widely studied. ${ }^{[110]}$ In the following we describe the synthesis and structural characterization of $\left[(\mathrm{SnO})_{6}\left(\mathrm{R}_{2} \mathrm{Si}_{2} \mathrm{O}_{3}\right)_{2}\right]\left[\mathrm{R}=\left(2,6-i \mathrm{Pr}_{2} \mathrm{C}_{6} \mathrm{H}_{3}\right) \mathrm{N}\left(\mathrm{SiMe}_{3}\right)\right](3)$. This represents the first example of a hexatin(II)cage containing siloxane ligands. Interestingly compound 3 contains a central embedded tin oxide, in the form of a molecular $(\mathrm{SnO})_{6}$ motif between two $\mathrm{R}_{2} \mathrm{Si}_{2} \mathrm{O}_{3}$ fragments. To the best of our knowledge, there has been no previous report on the isolation and structural characterization of any molecular tin(II)oxide.

The reaction of the tin amide ${ }^{[95]} \mathrm{Sn}\left[\mathrm{N}\left(\mathrm{SiMe}_{3}\right)_{2}\right]_{2}$ with the N-bonded silanetriol ${ }^{[79]}$ $\mathrm{RSi}(\mathrm{OH})_{3}\left[\mathrm{R}=\left(2,6-i \mathrm{Pr}_{2} \mathrm{C}_{6} \mathrm{H}_{3}\right) \mathrm{N}\left(\mathrm{SiMe}_{3}\right)\right](\mathbf{1})$ in a $1.5: 1$ stoichiometric ratio afforded $\mathbf{3}$ in about $65.4 \%$ yield (Scheme 3 ). The reaction proceeds under elimination of $\mathrm{HN}\left(\mathrm{SiMe}_{3}\right)_{2}$ with a concomitant $\mathrm{Si}-\mathrm{O}-\mathrm{Sn}$ bond formation. 


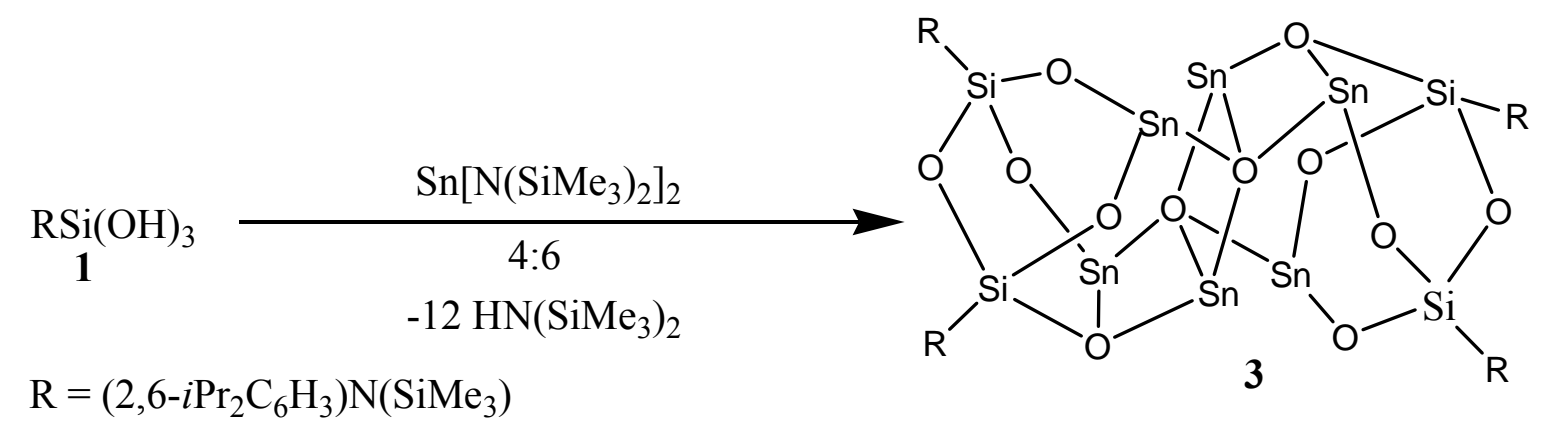

Scheme 3. Synthesis of compound 3.

Colorless crystals of $\mathbf{3}$ were obtained after four days at room temperature. Compound $\mathbf{3}$ is highly lipophilic and is soluble in a large number of common organic solvents including hydrocarbons such as hexane. Compound $\mathbf{3}$ has been fully characterized by means of analytical, spectroscopic, and single-crystal X-ray diffraction studies. A remarkable feature of the stannasiloxane $\mathbf{3}$ is its high thermal stability. It is stable up to its melting point of $307^{\circ} \mathrm{C}$ at which point the color of the compound turns into black brown. The EI-mass spectrum of $\mathbf{3}$ shows a highly intense peak at $1740(100 \%)\left[M^{+}-270\right]$ indicating the stability of the $\mathrm{Sn}_{6} \mathrm{Si}_{4} \mathrm{O}_{12}$ core under these conditions. The ${ }^{29} \mathrm{Si}$ NMR shows the presence of two resonances at 7.3 and $70.2 \mathrm{ppm}$. The latter corresponds to $\delta \mathrm{SiO}_{3} \mathrm{~N}$ while the former is assigned to $\delta \mathrm{SiMe}_{3} \mathrm{~N}$. The ${ }^{119} \mathrm{Sn}$ NMR of $\mathbf{3}$ shows three signals $(-138.6,-290.5$ and $-393.1 \mathrm{ppm})$ corresponding to the three types of tin present in $\mathbf{3}$.

Compound $\mathbf{3}$ is formed as a result of the reaction of the in situ generated disiloxanetetrol $\left[\left(\mathrm{RSi}(\mathrm{OH})_{2}\right)_{2} \mathrm{O}\right]$ with $\mathrm{Sn}\left[\mathrm{N}\left(\mathrm{SiMe}_{3}\right)_{2}\right]_{2}$. Such self-condensation of silanetriols has been reported by us earlier. ${ }^{[111]}$ Further, the water liberated from the condensation of the two silanetriol molecules assists in the formation of $\mathrm{SnO}$ from $\mathrm{Sn}\left[\mathrm{N}\left(\mathrm{SiMe}_{3}\right)_{2}\right]_{2}$.

Compound 3 crystallizes in the monoclinic space group $P 2_{1} / c$ along with one molecules of THF, one half molecule of hexane and half of the molecule of $\mathbf{3}$ in the asymmetric unit. The molecular structure of $\mathbf{3}$ is shown in Figure 4 . The core structure of $\mathbf{3}$ along with selected metric parameters are given in Figure 5. 


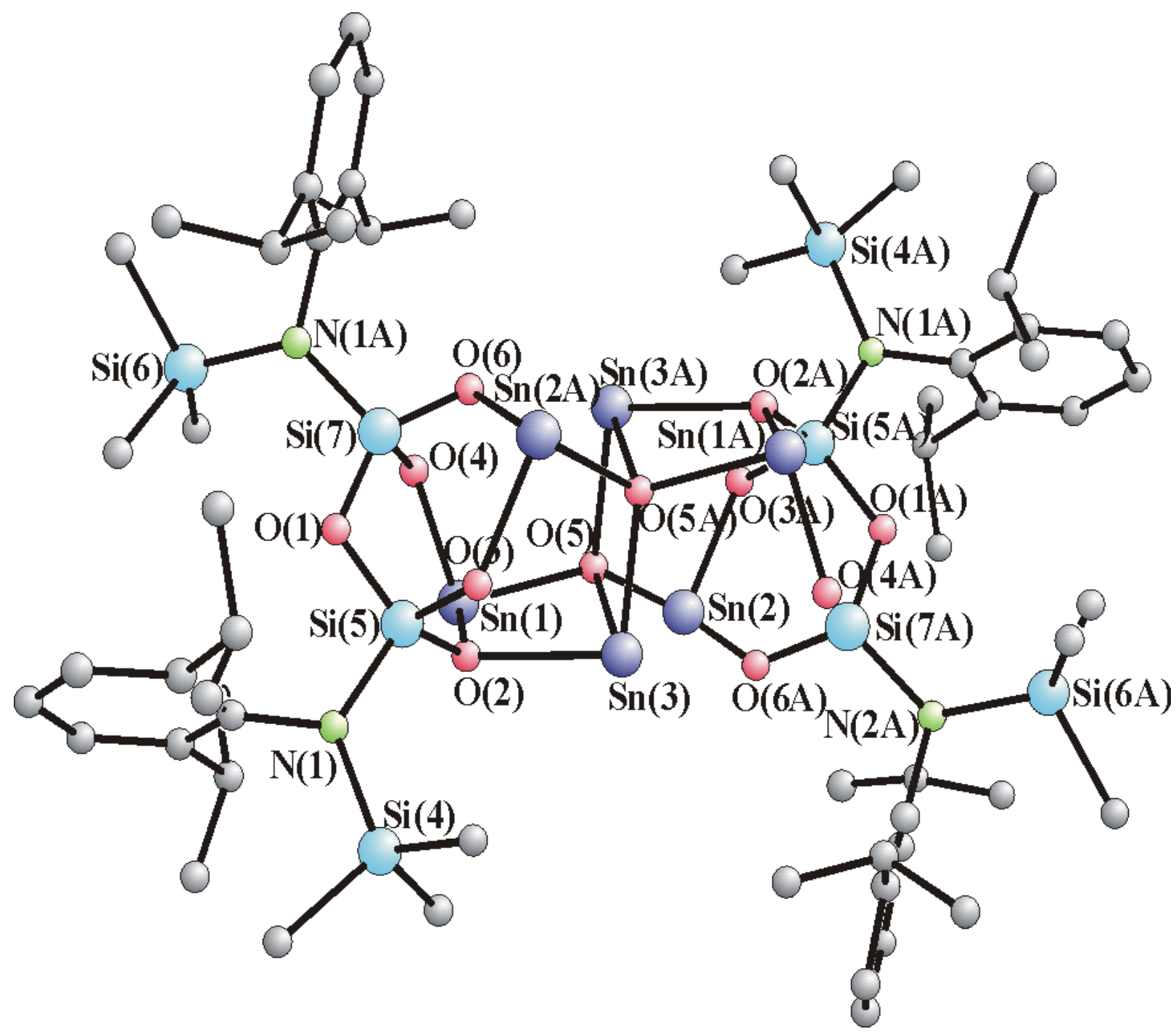

Figure 4. Molecular structure of $\mathbf{3}$ in the crystal.

The structure of $\mathbf{3}$ contains two centrosymmetrically related siloxane ligands that bind a central hexatin motif (Figure 4). The tin core consists of three mutually perpendicular $\mathrm{Sn}_{2} \mathrm{O}_{2}$ four-membered rings. The two oxygens of the central distannoxane are linked further to two other tin centers ( $\operatorname{Sn} 2$ and $\mathrm{Sn} 2 \mathrm{~A})$. It is important to note that none of the tins have any other ligands in their coordination environment except oxygen. Thus, the $(\mathrm{SnO})_{6}$ motif may be considered as representing a trapped molecular form of tin(II)oxide. All the six tin centers in $\mathbf{3}$ are tri-coordinate. It is interesting to note that in the solid state structure of tin(II) oxide the coordination environment of tin is four, where the tin is positioned in the apex of a square pyramid. $^{[1]}$ The shortest $\mathrm{Sn}-\mathrm{O}$ distances seen in $\mathbf{3}$ are for $\mathrm{Sn}(1)-\mathrm{O}(4)[2.025(2) \AA]$ and 
$\mathrm{Sn}(2 \mathrm{~A})-\mathrm{O}(3)$ bonds $[2.060(2) \AA]$ while the longest distances are found for $\mathrm{Sn}(3)-\mathrm{O}(5 \mathrm{~A})$ [2.287(2) $\AA]$ and $\mathrm{Sn}(3)-\mathrm{O}(2)$ bonds [2.288(2) $\AA]$. It is interesting to compare these distances with those observed in other tin(II) siloxanes. Thus, in $\left[\left\{\mathrm{Sn}-(\mu-\mathrm{O} t \mathrm{Bu})\left(\mathrm{OSiPh}_{3}\right)\right\}_{2}\right]$ which contains a four-membered $\mathrm{Sn}_{2} \mathrm{O}_{2}$ ring with a Sn-O distance of 2.084(4) $\AA^{[106]}$ In the case of $\left[\mathrm{Ca}\left\{\mathrm{Sn}\left(\mu-\mathrm{OSiMe} e_{2} t \mathrm{Bu}\right)_{3}\right\}_{2}\right]$ which contains two $\mathrm{SnO}_{3}$ motifs binding to a central calcium the average Sn-O distance is $2.106(7) \AA \AA^{[109]}$ In the case of tin(II) oxide itself the Sn-O distance has been reported as $2.21 \AA^{[1]}$

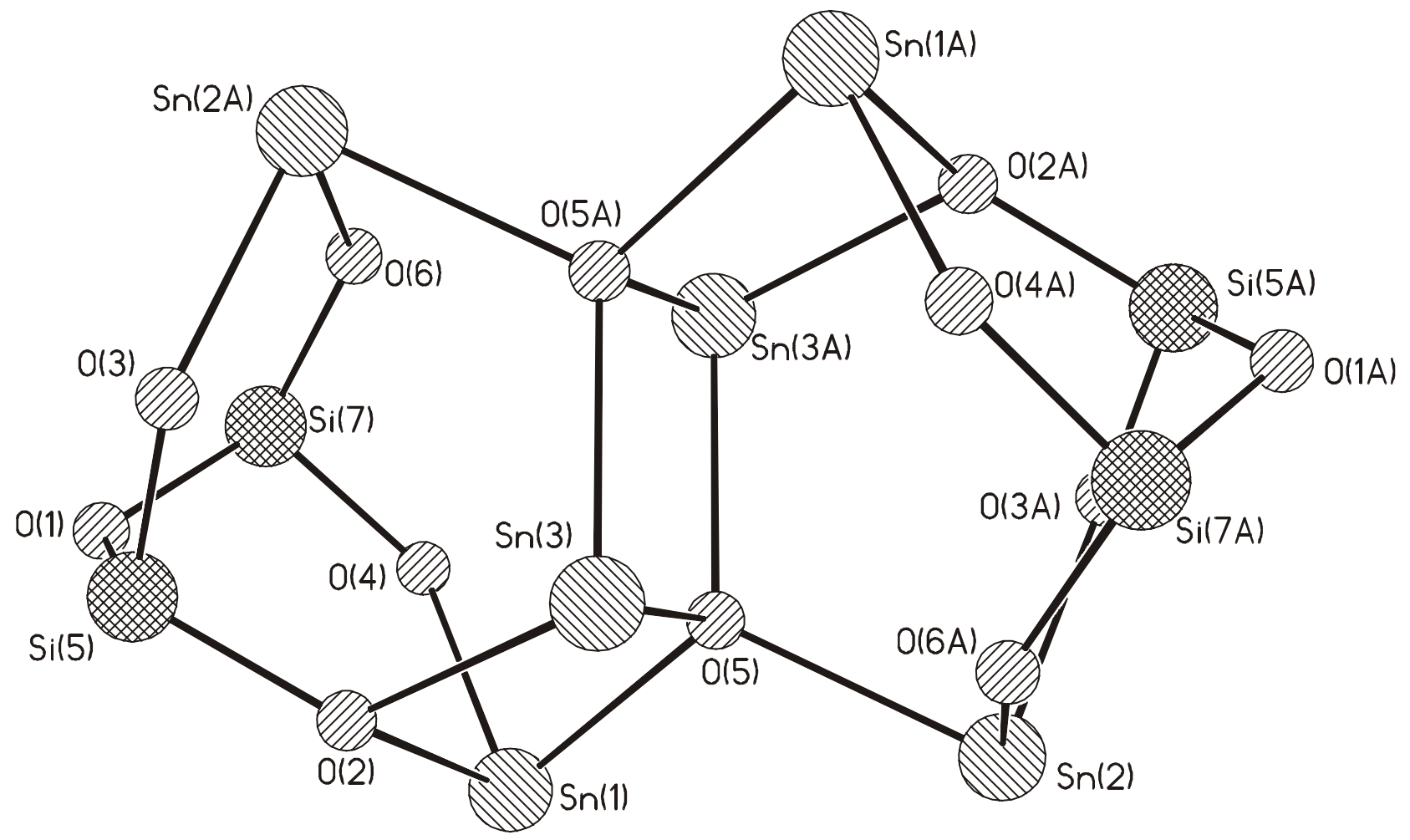

Figure 5. Core structure of $\mathbf{3}$. The substituents on silicon have been omitted for the sake of clarity. Selected bond lengths $[\AA]$ and angles $\left[^{\circ}\right]: \operatorname{Sn}(1)-\mathrm{O}(5) 2.190(2), \operatorname{Sn}(1)-\mathrm{O}(2) 2.141(2)$, $\mathrm{Sn}(1)-\mathrm{O}(4)$ 2.025(2), $\mathrm{Sn}(2)-\mathrm{O}(5)$ 2.184(2), $\mathrm{Sn}(2 \mathrm{~A})-\mathrm{O}(6)$ 2.095(2), $\mathrm{Sn}(2 \mathrm{~A})-\mathrm{O}(3)$ 2.060(2), $\mathrm{Sn}(3)-\mathrm{O}(2)$ 2.288(2), $\mathrm{Sn}(3)-\mathrm{O}(5) \quad 2.190(2), \mathrm{Sn}(3)-\mathrm{O}(5 \mathrm{~A}) \quad 2.287(2), \mathrm{Sn}(3 \mathrm{~A})-\mathrm{O}(5) \quad 2.287(2)$; $\mathrm{Sn}(1)-\mathrm{O}(2)-\mathrm{Sn}(3)$ 102.42(6), $\mathrm{Sn}(2)-\mathrm{O}(5)-\mathrm{Sn}(1)$ 112.66(7), $\mathrm{Sn}(2)-\mathrm{O}(5)-\mathrm{Sn}(3)$ 107.34(6), $\mathrm{Sn}(1)-$ $\mathrm{O}(5)-\mathrm{Sn}(3)$ 104.08(6), $\mathrm{Sn}(2)-\mathrm{O}(5)-\mathrm{Sn}(3 \mathrm{~A})$ 115.21(6), Sn(1)-O(5)-Sn(3A) 112.82(7), Sn(3)$\mathrm{O}(5)-\mathrm{Sn}(3 \mathrm{~A})$ 103.47(6), $\mathrm{Sn}(7)-\mathrm{O}(6)-\mathrm{Sn}(2 \mathrm{~A})$ 132.46(9), O(2)-Sn(3)-O(5A) 98.77(6), O(2)$\mathrm{Sn}(3)-\mathrm{O}(5)$ 73.40(6), O(2)-Sn(1)-O(5) 76.36(6), O(3A)-Sn(2)-O(5) 87.34(6), O(4)-Sn(1)-O(2) 
92.17(6), $\quad \mathrm{O}(4)-\mathrm{Sn}(1)-\mathrm{O}(5) \quad 91.39(6), \quad \mathrm{O}(5)-\mathrm{Sn}(3)-\mathrm{O}(5 \mathrm{~A}) \quad$ 76.53(6), $\quad \mathrm{O}(6 \mathrm{~A})-\mathrm{Sn}(2)-\mathrm{O}(3 \mathrm{~A})$ 92.49(6), $\mathrm{O}(6 \mathrm{~A})-\mathrm{Sn}(2)-\mathrm{O}(5) 81.30(6)$.

The bond angles around $\operatorname{Sn}(3)$ in $\mathbf{3}$ add up to $249^{\circ}$ while those at $\operatorname{Sn}(1)$ and $\operatorname{Sn}(2)$ add up to $260^{\circ}$ and $263^{\circ}$ respectively. There are three different kinds of oxygens in the structure of 3. Thus, there are four di-coordinate oxygens that bridge $\mathrm{Si}$ and $\mathrm{Sn}[\mathrm{O}(3), \mathrm{O}(4), \mathrm{O}(6)]$ or a $\mathrm{Si}$ [Si $[\mathrm{O}(1)]]$. The angles at all of these oxygens are much less than $180^{\circ}$, the largest being at $\mathrm{O}(6)\left(132.42^{\circ}\right)$ and the smallest at $\mathrm{O}(1)\left(121.20^{\circ}\right)$. There is only one tri-coordinate oxygen $\mathrm{O}(2)$ that caps two tins and one silicon. The other oxygen $\mathrm{O}(5)$ is tetra-coordinate and bridges four tin centers.

Concisely, we have reported herein a novel hexameric stannasiloxane $\mathbf{3}$ containing tin in a formal oxidation state of + II. The structure of 3 contains a central $(\mathrm{SnO})_{6}$ motif enclosed by two outer $\mathrm{R}_{2} \mathrm{Si}_{2} \mathrm{O}_{3}$ siloxane ligands. 


\subsection{Heavy Metal Containing Polyhedral Metallasiloxane Derived from an}

\section{Aminosilanetriol: Synthesis and Structural Characterization of$$
\left[(\mathrm{PbO})_{6}\left(\mathrm{R}_{2} \mathrm{Si}_{2} \mathrm{O}_{3}\right)_{2}\right]\left[\mathrm{R}=\left(2,6-i \mathrm{Pr}_{2} \mathrm{C}_{6} \mathrm{H}_{3}\right) \mathrm{N}\left(\mathrm{SiMe}_{3}\right)\right]
$$

Recently, we have been intrigued by the varied products obtained in the reaction of $\mathrm{RSi}(\mathrm{OH})_{3}$ with tin substrates. Thus, while tin(IV) reagents such as $\mathrm{PhSnCl}_{3}$ react with $\mathrm{RSi}(\mathrm{OH})_{3}$ to afford the cubic compound $\left[\mathrm{RSiO}_{3} \mathrm{SnPh}\right]_{4}$ or the bicyclic compound $\left[\left(\mathrm{RSiO}_{3}\right)_{2}(\mathrm{PhSn})_{3}\right]^{[81 \mathrm{a}]}$ analogous reaction with $\mathrm{Sn}\left[\mathrm{N}\left(\mathrm{SiMe}_{3}\right)_{2}\right]_{2}$ proceeds in an entirely different manner. The product of this reaction shows that a molecular $(\mathrm{SnO})_{6}$ could be trapped in a $\mathrm{Sn}(\mathrm{II})$ siloxane. ${ }^{[121]}$ In spite of the diverse and varied polyhedral metallasiloxanes, that have been synthesized from silanetriols and monosilanols, the number of structurally characterized metallasiloxanes containing heavy main group metals are very rare ${ }^{[113-118]}$ It is to be noted that uranium containing silicon rich metallasiloxanes have been derived from incompletely condensed silsesquioxanes and the metal/silicon ratio in these compounds is very low. ${ }^{[119]}$ We now report the synthesis and structural characterization of a novel hexa-lead assembly $\left[(\mathrm{PbO})_{6}\left(\mathrm{R}_{2} \mathrm{Si}_{2} \mathrm{O}_{3}\right)_{2}\right]\left[\mathrm{R}=\left(2,6-\mathrm{iPr}_{2} \mathrm{C}_{6} \mathrm{H}_{3}\right) \mathrm{N}\left(\mathrm{SiMe}_{3}\right)\right](4)$, which contains a $\mathrm{Pb} / \mathrm{Si}$ ratio of 6:4. Apart from being a unique example of a metallasiloxane containing two-fused cages, compound 4 also can be envisaged as possessing an embedded internal $(\mathrm{PbO})_{6}$ molecular lead(II)oxide enveloped by an external siloxane sheath.

The synthesis of compound 4 is accomplished in about 51\% yield and involves a 1.5:1 reaction of the lead(II) amide ${ }^{[95]} \mathrm{Pb}\left[\mathrm{N}\left(\mathrm{SiMe}_{3}\right)_{2}\right]_{2}$ with the aminosilanetriol ${ }^{[79]} \mathrm{RSi}(\mathrm{OH})_{3}[\mathrm{R}=$ (2,6-i $\left.\left.\mathrm{Pr}_{2} \mathrm{C}_{6} \mathrm{H}_{3}\right) \mathrm{N}\left(\mathrm{SiMe}_{3}\right)\right]$ (1) (Scheme 4). 


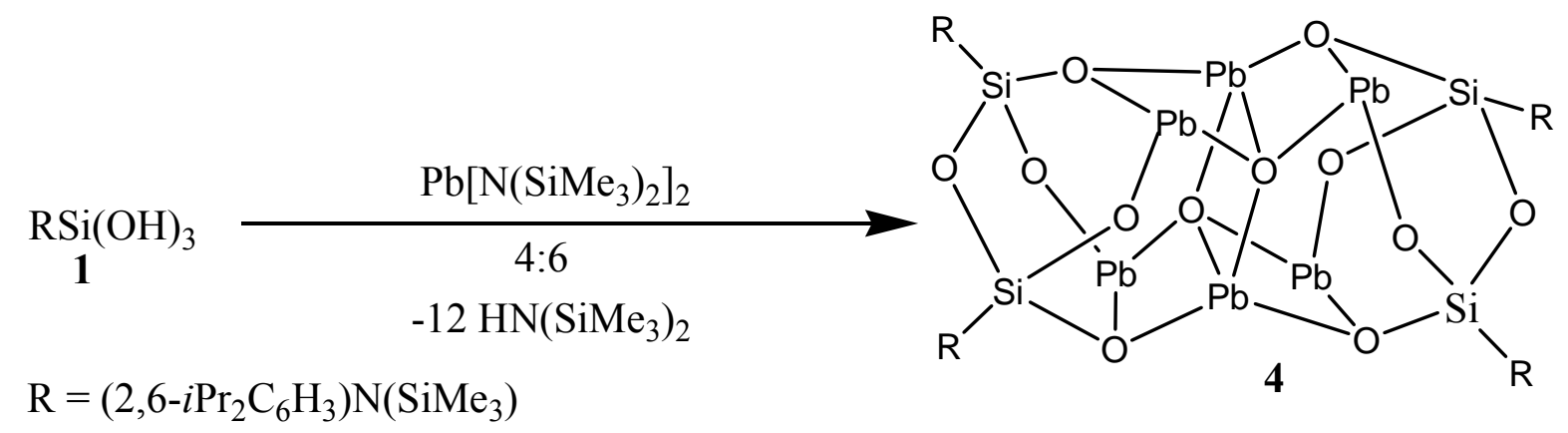

Scheme 4: Synthesis of compound 4.

A notable feature of the reaction is that the silanetriol undergoes a self-condensation to generate the disiloxanetetrol $\left[\left(\mathrm{RSi}(\mathrm{OH})_{2}\right)_{2} \mathrm{O}\right]$ which further reacts with the lead(II) amide. Such a condensation reaction has been noted by us earlier. ${ }^{[111]}$

Compound 4 is soluble in a large number of common organic solvents including hexane. It is thermally stable as evidenced by its high decomposition point $259{ }^{\circ} \mathrm{C}$. Further compound 4 is stable under the EI-mass condition and shows the parent peak at $2541(100 \%)$ $\left[M^{+}\right]$(Figure 6). The ${ }^{29} \mathrm{Si}$ NMR of 4 exhibits two resonances (4.4 and $-74.8 \mathrm{ppm}$ ). The latter corresponds to $\delta \mathrm{SiO}_{3} \mathrm{~N}$ while the former is due to $\delta \mathrm{SiMe}_{3} \mathrm{~N}$. In the infrared spectrum the $\widetilde{v}$ $\mathrm{Pb}-\mathrm{O}-\mathrm{Si}$ is preliminarily assigned to $881.8 \mathrm{~cm}^{-1}$. $^{113]}$

Compound 4 crystallizes in the monoclinic space group $P 2_{1} / n$ along with four molecules of THF per molecule. The molecular structure of 4 is given in Figure 7 . The $\mathrm{Pb}_{6} \mathrm{O}_{12} \mathrm{Si}_{4}$ core is shown in Figure 8. Selected metric parameters of $\mathbf{4}$ are summarized in Figure 8. 

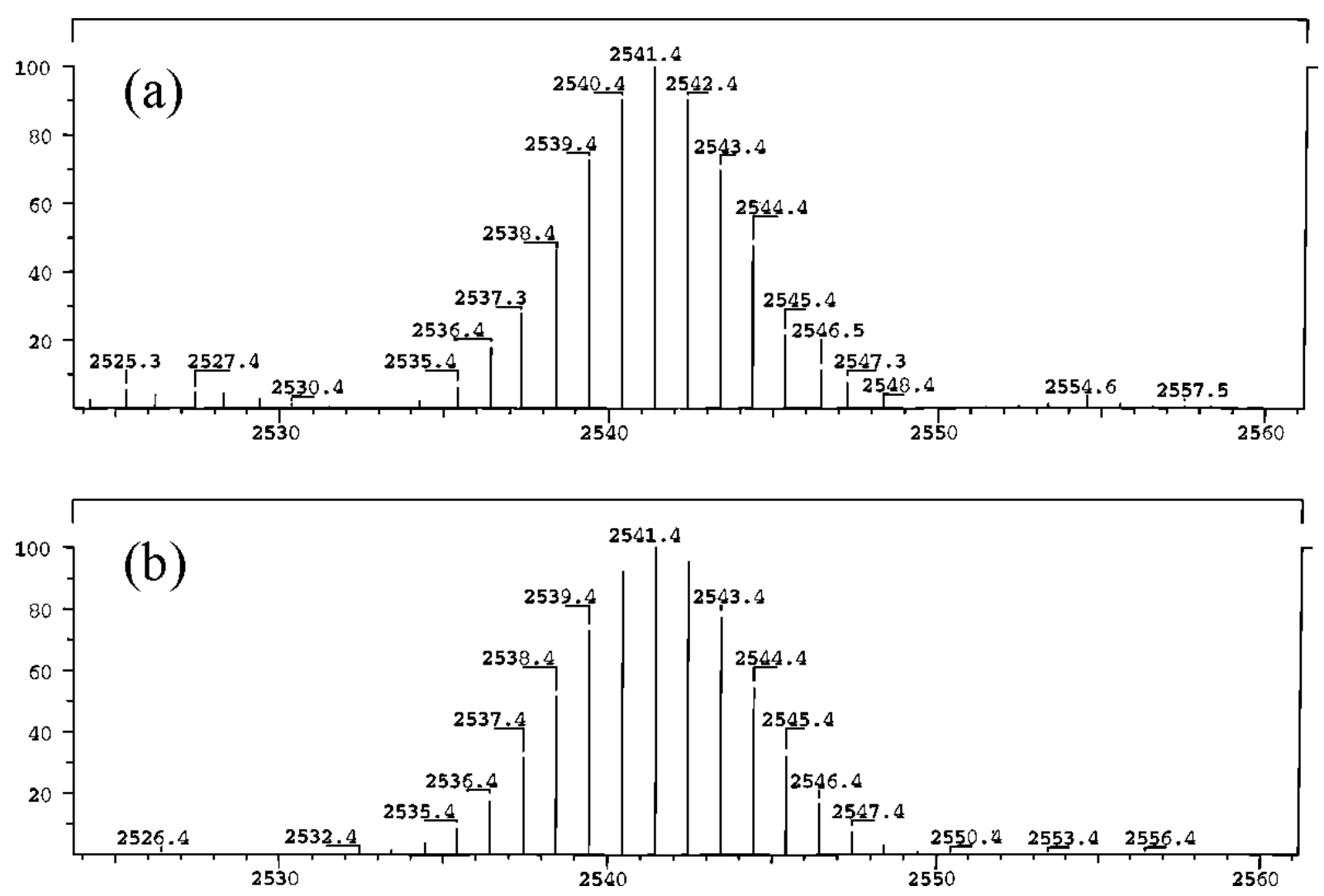

Figure 6. (a) A partial mass spectrum (electron impact) of $\mathbf{4}$ showing the parent ion in the $\mathrm{m} / \mathrm{z}$ 2535 to 2548 range. (b) A simulated isotope cluster pattern expected for the $\mathrm{C}_{60} \mathrm{H}_{104} \mathrm{~N}_{4} \mathrm{O}_{12}$ $\mathrm{Pb}_{6} \mathrm{Si}_{8}$ composition.

The molecular structure of $\mathbf{4}$ can be visualized in the following way. The molecule contains two centrosymmetrically related $\left(\mathrm{Pb}_{4} \mathrm{O}_{7} \mathrm{Si}_{2}\right)$ units that are fused with each other to generate a central diplumboxane motif $\left(\mathrm{Pb}_{2} \mathrm{O}_{2}\right)$. Each half of the molecule can be described as possessing a drum-like cage structure. The top and bottom of the drum are comprised of two puckered $\left(\mathrm{Pb}_{2} \mathrm{O}_{3} \mathrm{Si}\right)$ six-membered rings while the sides are made up of three contiguous $\left(\mathrm{Pb}_{2} \mathrm{O}_{2}\right)$ four-membered rings. In contrast, the recently reported ${ }^{[112]}$ tin(II)siloxane contains two centrosymmetrically related bicyclic $\mathrm{Si}_{2} \mathrm{Sn}_{2} \mathrm{O}_{5}$ rings that are connected to each other by the central four-membered $\mathrm{Sn}_{2} \mathrm{O}_{2}$ ring where each tin is tri-coordinated. Interestingly, this arrangement leads to an incomplete cage on either side of the distannoxane motif. An alternative way of viewing compound 4 is that it contains a $(\mathrm{PbO})_{6}$ motif, in the form of fused $\mathrm{Pb}_{2} \mathrm{O}_{2}$ rings, which are enclosed within two $\left(\mathrm{R}_{2} \mathrm{Si}_{2} \mathrm{O}_{3}\right)$ ligands. While the central lead centers 
$\mathrm{Pb}(2)$ and $\mathrm{Pb}(2 \mathrm{~A})$ are four-coordinate (4O) the others are three-coordinate (3O). Interestingly, in the solid-state structure of $\mathrm{PbO}$ the coordination number of lead is four (4O) where lead occupies the apex of a square-pyramid. ${ }^{[1]}$

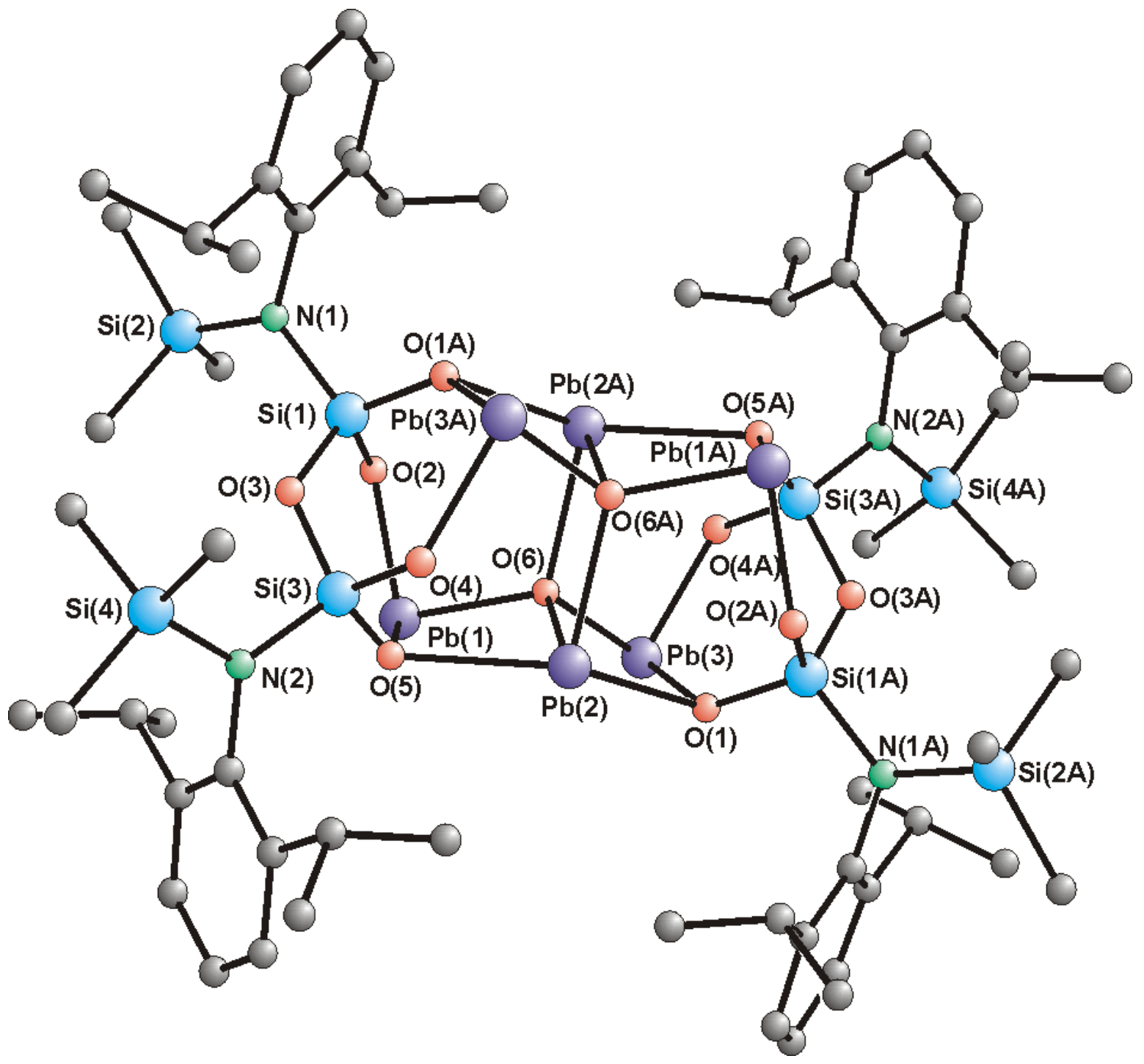

Figure 7. Molecular structure of 4 in the crystal.

Three types of $\mathrm{Pb}-\mathrm{O}$ distances are found in $\mathbf{4}$. The shortest distances observed are for $\mathrm{Pb}(1)-\mathrm{O}(2)[2.155(3) \AA]$ and $\mathrm{Pb}(3)-\mathrm{O}(4 \mathrm{~A})$ bonds $[2.163(3) \AA]$. The longest distances found are for $\mathrm{Pb}(2)-\mathrm{O}(5)[2.528(3) \AA]$ and $\mathrm{Pb}(2)-\mathrm{O}(1)$ bonds [2.546(3) $\AA$ ]. These metric parameters may be compared with other lead(II) siloxanes: $\left(\left[\mathrm{Pb}_{4}\left(\mathrm{OSiPh}_{3}\right)_{6} \mathrm{O}\right][2.25-2.49 \AA]\right.$; ${ }^{[113]}$ $\left.\mathrm{NaPb}\left[\mathrm{OSi}(\mathrm{O} t \mathrm{Bu})_{3}\right]_{3}[2.12-2.15 \AA] ;{ }^{[114]}\left[\mathrm{Pb}_{7}\left(\mathrm{OSiMe}_{3}\right)_{10} \mathrm{O}_{2}\right][2.263(8)-2.660(9) \AA]^{[115]}\right)$. 
There are three different kinds of oxygen in the structure of 4 . Three of these are dicoordinate and bridge either silicon and lead centers $[\mathrm{O}(2)$ and $\mathrm{O}(4)]$ or two silicon centers $[\mathrm{O}(3)]$. There are two tri-coordinate oxygens $\mathrm{O}(1)$ and $\mathrm{O}(5)$ that cap two lead centers and one silicon center. The other oxygen $\mathrm{O}(6)$ is tetra-coordinate and bridges four lead centers. The angles at all of these oxygens are much less than $180^{\circ}$, Thus, the bond angles at oxygens that bridge silicon and lead vary from $\left[128.51(16)^{\circ}\right] \mathrm{Si}(3)-\mathrm{O}(5)-\mathrm{Pb}(1)$ to $\left[109.41(15)^{\circ}\right] \mathrm{Si}(3)-\mathrm{O}(5)-$ $\mathrm{Pb}(2)$. In contrast the bond angles that bridge two lead centers vary from [114.91 (12) ${ }^{\circ} \mathrm{Pb}(1)-$ $\mathrm{O}(6)-\mathrm{Pb}(2 \mathrm{~A})$ to $\left[97.79(10)^{\circ}\right] \mathrm{Pb}(1)-\mathrm{O}(5)-\mathrm{Pb}(2)$.

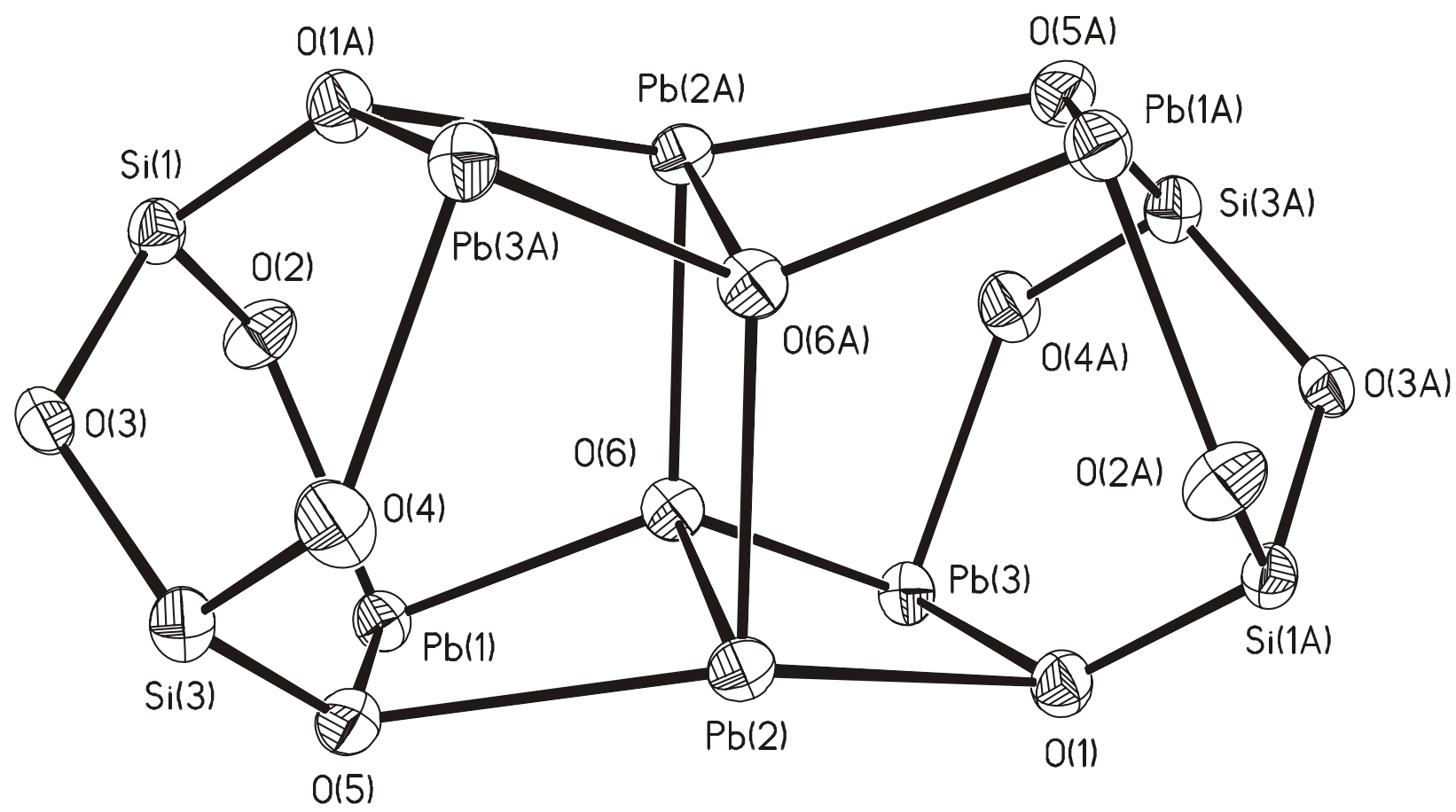

Figure 8. ORTEP core structure of 4 . The substituents on silicon have been omitted for the sake of clarity. Selected bond lengths $[\AA]$ and angles $\left[^{\circ}\right]$ : $\mathrm{Pb}(1)-\mathrm{O}(2) 2.155(3), \mathrm{Pb}(1)-\mathrm{O}(5)$ 2.267(3), $\mathrm{Pb}(1)-\mathrm{O}(6)$ 2.247(3), $\mathrm{Pb}(2)-\mathrm{O}(5)$ 2.528(3), $\mathrm{Pb}(2)-\mathrm{O}(6 \mathrm{~A})$ 2.397(3), $\mathrm{Pb}(2)-\mathrm{O}(6)$ 2.276(3), $\mathrm{Pb}(2)-\mathrm{O}(1)$ 2.546(3), $\mathrm{Pb}(2 \mathrm{~A})-\mathrm{O}(6)$ 2.397(3), $\mathrm{Pb}(3)-\mathrm{O}(1)$ 2.245(3), $\mathrm{Pb}(3)-\mathrm{O}(4 \mathrm{~A})$ 2.163(3), $\mathrm{Pb}(3)-\mathrm{O}(6)$ 2.242(3); $\mathrm{O}(2)-\mathrm{Pb}(1)-\mathrm{O}(6)$ 87.81(11), $\mathrm{O}(2)-\mathrm{Pb}(1)-\mathrm{O}(5)$ 91.87(10), $\mathrm{O}(6)-$ $\mathrm{Pb}(1)-\mathrm{O}(5)$ 79.09(10), $\mathrm{O}(6)-\mathrm{Pb}(2)-\mathrm{O}(6 \mathrm{~A})$ 77.28(10), $\mathrm{O}(6)-\mathrm{Pb}(2)-\mathrm{O}(5)$ 73.29(9), $\mathrm{O}(6 \mathrm{~A})-\mathrm{Pb}(2)-$ $\mathrm{O}(5)$ 101.59(9), O(6)-Pb(2)-O(1) 72.24(9), O(6A)-Pb(2)-O(1) 99.31(9), O(5)-Pb(2)-O(1) 
134.16(9), $\mathrm{O}(4 \mathrm{~A})-\mathrm{Pb}(3)-\mathrm{O}(6) \quad 88.27(11), \quad \mathrm{O}(4 \mathrm{~A})-\mathrm{Pb}(3)-\mathrm{O}(1) \quad 93.22(10), \quad \mathrm{O}(6)-\mathrm{Pb}(3)-\mathrm{O}(1)$ 78.90(10).

In short, we have reported a novel hexameric lead(II) siloxane $\mathbf{4}$ containing lead in a formal oxidation state of + II. Compound $\mathbf{4}$ possesses a fused cage structure where each half of the cage is itself a drum-like polyhedron. It is also possible to consider the structure of 4 containing a trapped $(\mathrm{PbO})_{6}$ motif that is linked to two $\mathrm{R}_{2} \mathrm{Si}_{2} \mathrm{O}_{3}$ ligands. 


\subsection{Polyhedral Antimony(III), and Bismuth(III) Siloxanes: Synthesis, Spectral studies, and Structural Characterization of $\left[\mathrm{Sb}\left(\mathrm{O}_{3} \mathrm{SiR}\right)\right]_{4}$ and $\left[\mathrm{Bi}_{12}\left(\mathrm{O}_{3} \mathrm{SiR}\right)_{8}\left(\mu_{3}-\mathrm{O}\right)_{4} \mathrm{Cl}_{4}(\mathrm{THF})_{8}\right]\left(\mathrm{R}=\left(2,6-\mathrm{PPr}_{2} \mathrm{C}_{6} \mathrm{H}_{3}\right) \mathrm{N}\left(\mathrm{SiMe}_{3}\right)\right)$}

There has been great, recent interest in the synthesis and characterization of metallasiloxanes as describing in the preceding sections, ${ }^{[58,66,67]}$ although the first reports dates back to the end of the nineteenth century. ${ }^{[68]}$ The core structures of the Group $13^{[77]}$ and titanium $^{[81 b]}$ containing cubic metallasiloxanes act as the secondary building blocks (SBU) of Group 13 and titanium containing zeolites. Furthermore, these compounds are quite valuable in understanding the reaction path and the intermediate steps formed during the catalytic processes particularly those involving silica supported transition metal catalysts. ${ }^{[86,87]}$ Moreover, the metallasiloxanes can also be considered as precursors for silicon polymers containing metal centers in the polymeric backbone. ${ }^{[120]}$

In view of the importance of such compounds, we have been actively involved in the synthesis of metallasiloxanes starting from lipophilic N-bonded silanetriol $\mathrm{RSi}(\mathrm{OH})_{3}(\mathrm{R}=$ (2,6-i $\left.\left.\mathrm{Pr}_{2} \mathrm{C}_{6} \mathrm{H}_{3}\right) \mathrm{N}\left(\mathrm{SiMe}_{3}\right)\right)$ (1) with metal alkyls, metal alcoholates, and metal amides as the precursor under the elimination of alkanes, alcohols, and amines respectively. ${ }^{[58,64,67]}$ Among them, compounds with a cubic core structure are of particular interest. ${ }^{[77,81 b, 82]}$ In this direction, we synthesized a range of Al-, Ge-, In-, Ge-, Sn- Ti-, Fe-, and Zn- containing siloxanes with cubic $\mathrm{M}_{4} \mathrm{O}_{12} \mathrm{Si}_{4}$ frameworks. With this in mind, it was of interest to extend our studies towards the preparation of soluble analogous molecular antimony(III), and bismuth(III) containing siloxane frameworks. Previously, Schmidbaur ${ }^{[121 a, b]}$ and HubertPfalzgraf $^{[122 a]}$ et al. have reported on antimony(III) and bismuth(III) containing siloxane compounds which were obtained by use of $\mathrm{R}_{3} \mathrm{SiO}$. Feher et al. synthesized cubic Group 15 containing heterosilsesquioxanes by the "corner-capping" reaction starting from three- 
functional, incompletely condensed oligosilsesquioxanes $\left(c-\mathrm{C}_{6} \mathrm{H}_{11}\right)_{7} \mathrm{Si}_{7} \mathrm{O}_{9}(\mathrm{OH})_{3},{ }^{[123 \mathrm{a}]}$ those structures could not be completely solved except the phosphorus congener. However, these compounds have a metal/silicon ratio of 1:7. ${ }^{[123]}$ Recently, Mehring et al. reported on a polyhedral bismuth siloxane of composition $\left[\mathrm{Bi}_{22} \mathrm{O}_{26}\left(\mathrm{OSiMe}_{2} t \mathrm{Bu}\right)_{14}\right] .{ }^{[122 \mathrm{~d}]}$

In this paper we present the synthesis, spectral studies, and structural characterization of the $\left[\mathrm{Sb}\left(\mathrm{O}_{3} \mathrm{SiR}\right)\right]_{4} \quad(5)$ and $\left[\mathrm{Bi}_{12}\left(\mathrm{O}_{3} \mathrm{SiR}\right)_{8}\left(\mu_{3}-\mathrm{O}\right)_{4} \mathrm{Cl}_{4}(\mathrm{THF})_{8}\right] \quad(\mathbf{6}) \quad(\mathrm{R}=(2,6-$ $\left.\left.i \mathrm{Pr}_{2} \mathrm{C}_{6} \mathrm{H}_{3}\right) \mathrm{N}\left(\mathrm{SiMe}_{3}\right)\right)$. These compounds have the $\mathrm{Sb} / \mathrm{Si}$ and $\mathrm{Bi} / \mathrm{Si}$ ratios of $4: 4$ and 12:8 respectively. Compound $\mathbf{5}$ represents the first example of fully characterized cubic antimony(III) containing siloxane ligands. More recently, the antimony silicate ( $\mathrm{Sb} / \mathrm{Si}$ molar ratio of 1:1) has been found to be useful as a high selective ion exchanger for the removal of ${ }^{85} \mathrm{Sr}$ from nuclear waste solutions, ${ }^{[124]}$ whereas bismuth silicate, as an anion exchanger, ${ }^{[125]}$ has been used as a novel sorbent in thin layer chromatography. ${ }^{[126]}$ Furthermore, antimony and bismuth silicate glasses find a number of industrial and special applications such as, fiber optic amplifiers, ${ }^{[127]}$ high temperature superconductors, and capacitor layers in memory devices. $^{[128]}$

The reaction of (arylamino) silanetriol ${ }^{[79]} \mathrm{RSi}(\mathrm{OH})_{3}\left(\mathrm{R}=\left(2,6-i \mathrm{Pr}_{2} \mathrm{C}_{6} \mathrm{H}_{3}\right) \mathrm{N}\left(\mathrm{SiMe}_{3}\right)\right)(\mathbf{1})$ with antimony(III) amide ${ }^{[129]} \mathrm{Sb}\left(\mathrm{NMe}_{2}\right)_{3}$ in hexane and THF at room temperature with a 1:1 stoichiometric ratio afforded the cuboid antimony(III) siloxane $\left[\mathrm{Sb}\left(\mathrm{O}_{3} \mathrm{SiR}\right)\right]_{4}(\mathrm{R}=(2,6-$ $\left.\left.i \operatorname{Pr}_{2} \mathrm{C}_{6} \mathrm{H}_{3}\right) \mathrm{N}\left(\mathrm{SiMe}_{3}\right)\right)(\mathbf{5})$ in about $83 \%$ yield (Scheme 5). 


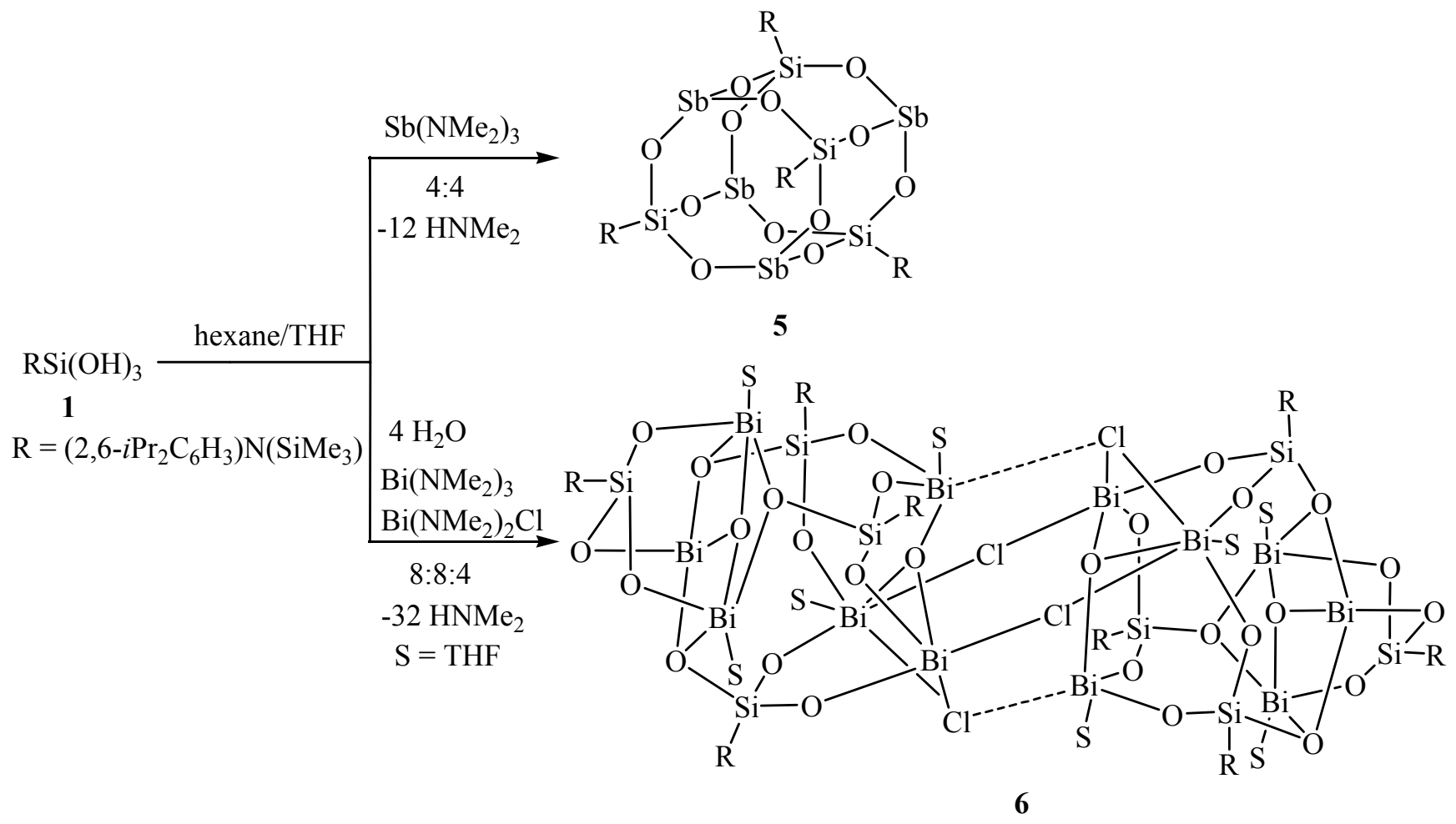

Scheme 5 .

The reaction proceeds under evolution of dimethylamine $\mathrm{HNMe}_{2}$, which results in the subsequent assembly of the three-dimentional $\mathrm{Si}-\mathrm{O}-\mathrm{Sb}$ frameworks. Compound $\mathbf{5}$ is highly soluble in common organic solvents such as hexane, benzene, toluene, ether or THF. Compound $\mathbf{5}$ has been fully characterized by means of analytical, spectroscopic, and singlecrystal X-ray diffraction studies. An interesting aspect of the antimony(III) siloxane $\mathbf{5}$ is that, in spite of the large molecular weight, the electron impact mass spectrum (EI-MS) of compound 5 reveals a strong parent molecular ion in the range of $m / z$ 1781-1792 ( $\left[M^{+}\right]$ 1784.2 relative intensity: $100 \%$ ) that possesses an isotopic cluster pattern that is also consistent with the expected composition as shown in Figure 9. This observation indicates that, under ionization conditions $(70 \mathrm{eV})$, the cubic core of compound $\mathbf{5}$ remains intact. Besides this, compound 5 does not melt up to $387^{\circ} \mathrm{C}$, at which point the color of the compound turns into black brown. The IR spectrum of compound $\mathbf{5}$ shows an absorption between 900 and $1000 \mathrm{~cm}^{-1}$, which could be attributed to $\mathrm{Si}-\mathrm{O}-\mathrm{Sb}$ stretching frequency. The ${ }^{1} \mathrm{H}$ NMR spectral data (in $\mathrm{C}_{6} \mathrm{D}_{6}$ ) and the integration of the intensities match well with the 
proposed structure of compound $\mathbf{5}$. The protons from the $-\mathrm{SiMe}_{3}$ groups resonate as a singlet $(\delta=0.25 \mathrm{ppm})$. Two sets of doublets of equal intensity appear at $\delta=1.23$ and $1.26 \mathrm{ppm}(J=$ $6.9 \mathrm{~Hz})$ for the two isopropyl methyl $\left(\mathrm{CH}\left(\mathrm{CH}_{3}\right)_{2}\right)$ protons, while a septet $(\delta=3.75 \mathrm{ppm}, J=$ $6.9 \mathrm{~Hz})$ is observed for the isopropyl methine $\left(\mathrm{CH}\left(\mathrm{CH}_{3}\right)_{2}\right)$ proton. The appearance of two different resonances for isopropyl groups is consistent with the crystal structure of $\mathbf{5}$ if the rotation of the aromatic groups about the $\mathrm{C}-\mathrm{N}$ bond is restricted. The aryl protons of compound 5 resonate as a multiplet in the range of $\delta=6.66$ to $6.69 \mathrm{ppm}$. The ${ }^{29} \mathrm{Si} \mathrm{NMR}$ spectrum of compound 5 (in $\mathrm{C}_{6} \mathrm{D}_{6}$ ) displays two single resonances for the $\mathrm{SiMe}_{3} \mathrm{~N}$ unit $(\delta=$ $4.42 \mathrm{ppm}$ ), and for the $\mathrm{SiO}_{3} \mathrm{~N}$ part ( $\delta=-91 \mathrm{ppm}$ ), indicating a high symmetry in solution.
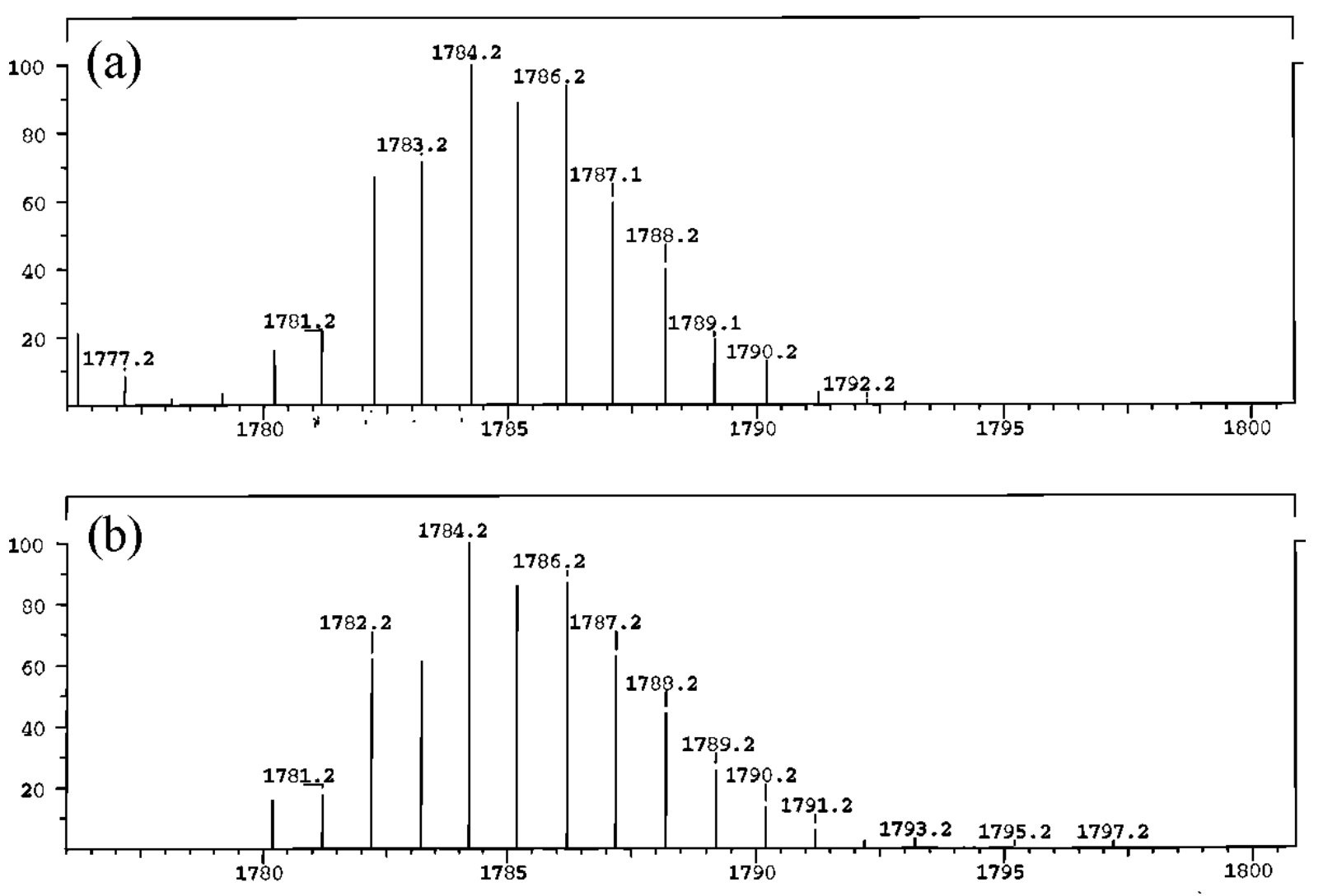

Figure 9. (a) A partial mass spectrum (electron impact) of $\mathbf{5}$ showing the parent ion in the $\mathrm{m} / \mathrm{z}$ 1781-1792 range. (b) A simulated isotope cluster pattern expected for the $\mathrm{C}_{60} \mathrm{H}_{104} \mathrm{~N}_{4} \mathrm{O}_{12} \mathrm{Sb}_{4} \mathrm{Si}_{8}$ composition. 
Unequivocal proof of the structure for compound $\mathbf{5}$ has been provided by the crystallographic analysis of single crystals. Single crystals of 5 suitable for X-ray structural determination were grown from their concentrated hexane/THF solution. Compound $\mathbf{5}$ crystallizes in the monoclinic space group $P 2_{1} / n$, along with two independent molecules and 2.68 molecules of THF in the asymmetric unit. Selected metric parameters of $\mathbf{5}$ are summarised in Figure 10. The ORTEP core structure diagram of both independent molecules of 5 are shown in Figure 10. The $\mathrm{Si}_{4} \mathrm{O}_{12} \mathrm{Sb}_{4}$ core structure can be defined by four silicon and four antimony atoms occupying alternate corners of the distorted cubic polyhedron. Each of the twelve $\mathrm{Si} \cdots \mathrm{Sb}$ edges is bridged by oxygen atoms in a $\mu$ bridging fashion. There are six $\mathrm{Si}_{2} \mathrm{O}_{4} \mathrm{Sb}_{2}$ eight-membered rings that define the faces of the cube, and each of these rings adopts a pseudo $C_{4}$ crown conformation.

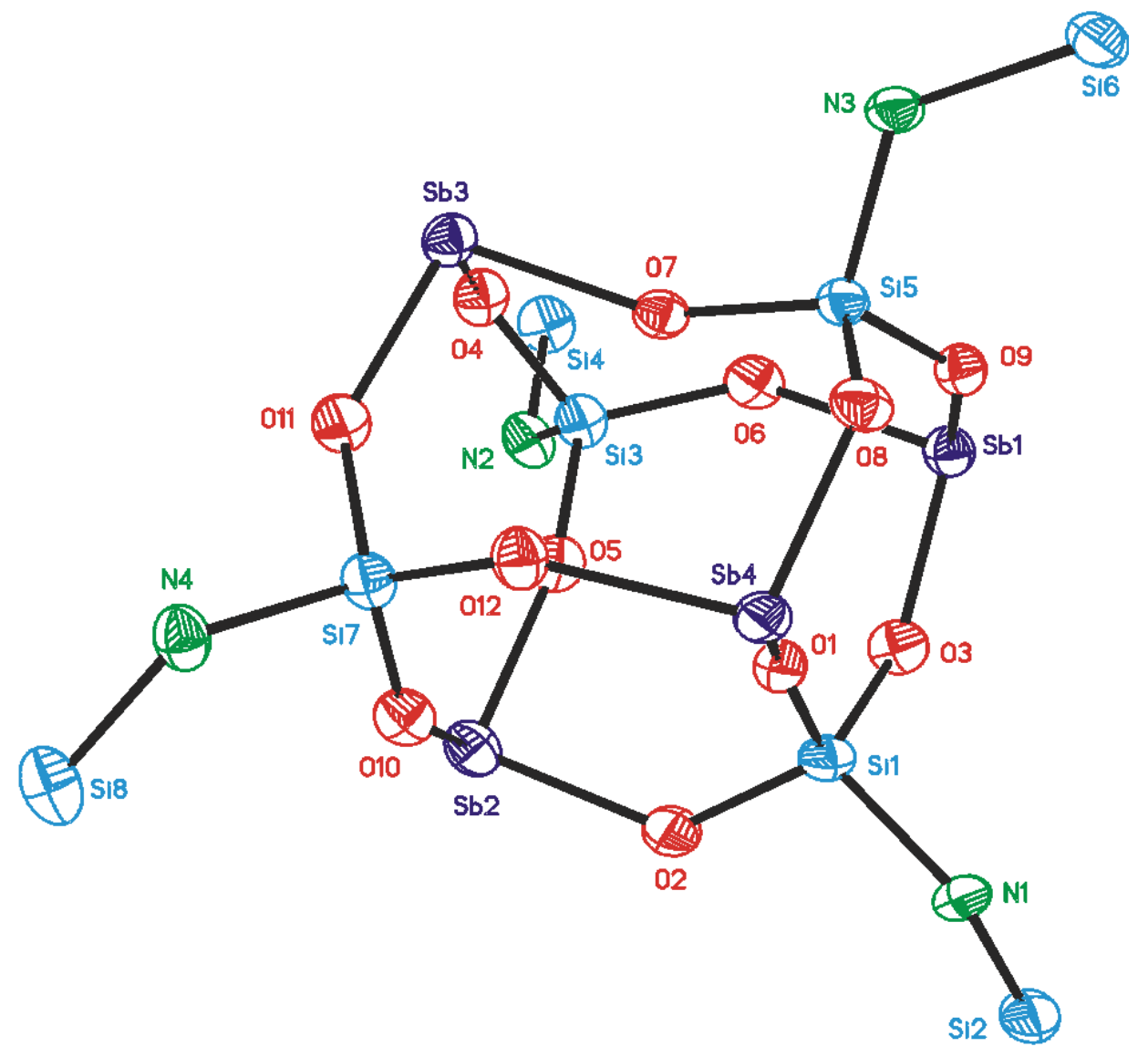




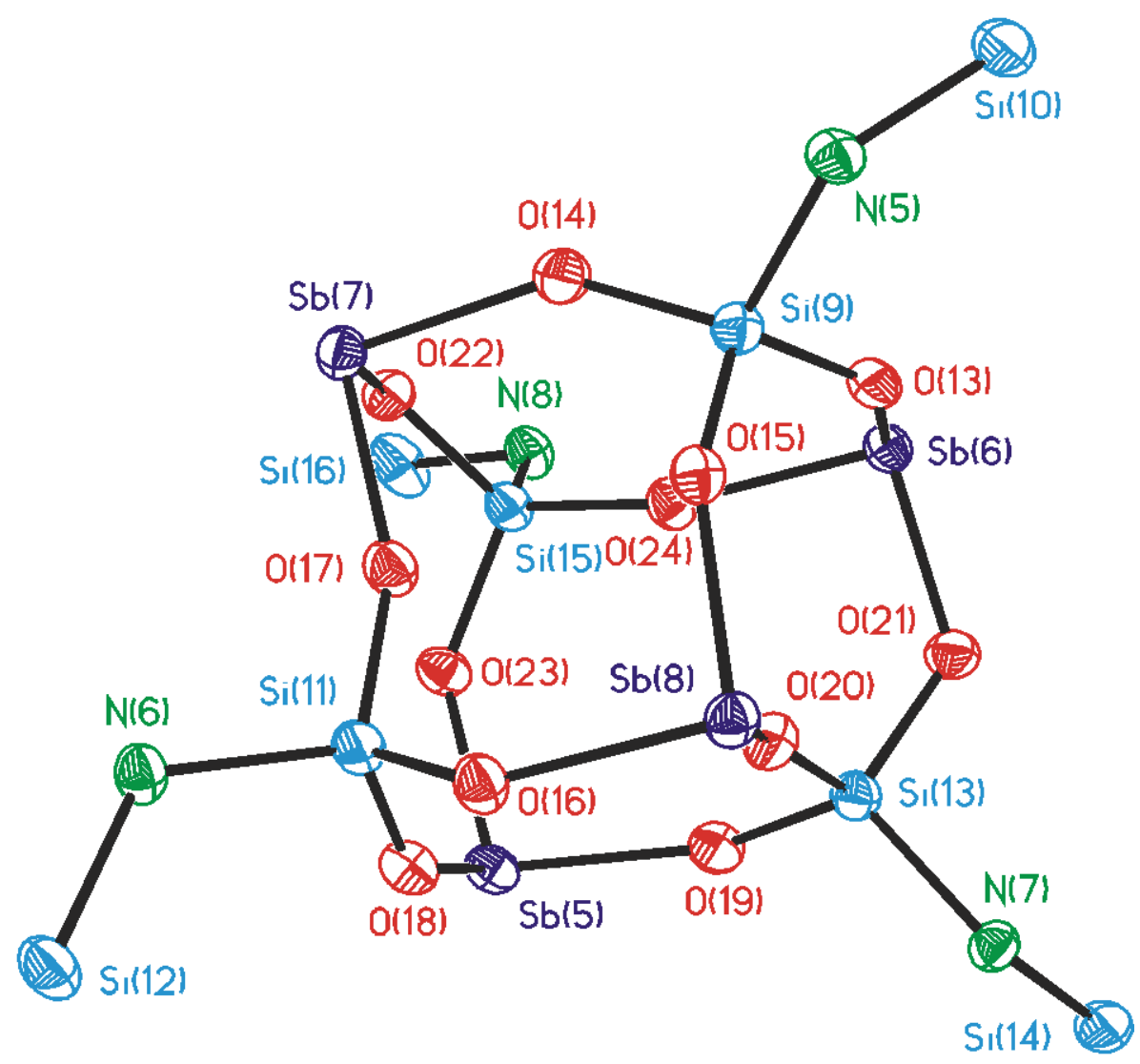

Figure 10. ORTEP diagram of cores of the two independent molecules of 5 with $50 \%$ probability. Most of the substituents on silicon atoms are omitted for the sake of clarity. Selected bond lengths $[\AA]$ and angles $\left[^{\circ}\right]$ : $\mathrm{Sb}(1)-\mathrm{O}(9)$ 1.951(3), $\mathrm{Sb}(1)-\mathrm{O}(6) 1.952(4), \mathrm{Sb}(1)-$ $\mathrm{O}(3)$ 1.954(3), Sb(2)-O(5) 1.917(3), Sb(2)-O(5) 1.917(3), Sb(2)-O(2) 2.943(3), Sb(2)-O(10) 1.951(3), $\quad \mathrm{Sb}(3)-\mathrm{O}(7)$ 1.931(3), $\mathrm{Sb}(3)-\mathrm{O}(4)$ 1.945(3), $\mathrm{Sb}(3)-\mathrm{O}(11)$ 1.951(3), $\mathrm{Sb}(4)-\mathrm{O}(8)$ 1.949(3), $\quad \mathrm{Sb}(4)-\mathrm{O}(12) \quad 1.953(3), \quad \mathrm{Si}(1)-\mathrm{O}(1)$ 1.603(4), $\quad \mathrm{Si}(1)-\mathrm{O}(3)$ 1.621(4), $\quad \mathrm{Si}(1)-\mathrm{O}(2)$ 1.638(4), Si(3)-O(5) 1.602(4); O(9)-Sb(1)-O(6) 98.40(14), O(6)-Sb(1)-O(3)100.43(14), O(5)$\mathrm{Sb}(2)-\mathrm{O}(2)$ 92.34(14), O(2)-Sb(2)-O(10) 96.73(14), O(7)-Sb(3)-O(4) 91.05(14), O(4)-Sb(3)O(11) 97.83(14), O(1)-Sb(4)-O(8) 92.06(14), O(8)-Sb(4)-O(12) 97.98(14), O(1)-Si(1)-O(3) 108.27(18), $\quad \mathrm{O}(3)-\mathrm{Si}(1)-\mathrm{O}(2) \quad 109.95(19), \quad \mathrm{O}(5)-\mathrm{Si}(3)-\mathrm{O}(6) \quad 108.70(19), \quad \mathrm{O}(6)-\mathrm{Si}(3)-\mathrm{O}(4)$ 110.42(19), O(7)-Si(5)-O(9) 108.90(18), O(9)-Si(5)-O(8) 109.69(18), O(12)-Si(7)-O(10) 112.75(19). 
It is interesting to note that none of the antimony atoms have any other ligands in their coordination environment except oxygen. The antimony atoms adopt distorted trigonal pyramidal geometry. The warped form of the trigonal pyramidal geometry may be attributed to the lone pair repulsions. The O-Sb-O angles are observed in the range of $91.1(1)^{\circ}[\mathrm{O}(4)-$ $\mathrm{Sb}(3)-\mathrm{O}(7)]$ to $100.4(1)^{\circ}[\mathrm{O}(3)-\mathrm{Sb}(1)-\mathrm{O}(6)]$ with the average angle of $95.6^{\circ}$. This value compares well with the data reported for $\left[\mathrm{Sb}\left(\mathrm{OSiMe}_{3}\right)_{3}\right]^{[121 \mathrm{a}]}\left[\mathrm{av} 95.16^{\circ}\right]$. However, the silicon atom shows nearly ideal tetrahedral geometry. The O-Si-O angles are observed in the range of $108.2(2)^{\mathrm{o}}[\mathrm{O}(20)-\mathrm{Si}(13)-\mathrm{O}(19)]$ to $112.8(2)^{\mathrm{o}}[\mathrm{O}(10)-\mathrm{Si}(1)-\mathrm{O}(12)]$ with an average angle of $109.7^{\circ}$

The Sb-O bond distances in 5 vary in the range of $1.917(3) \AA[\mathrm{Sb}(7)-\mathrm{O}(17)]$ to $1.955(3) \AA[\mathrm{Sb}(5)-\mathrm{O}(19)]$ with an average value of 1.940(4) $\AA$. These are slightly longer than the corresponding ones found for $\left[\mathrm{Sb}\left(\mathrm{OSiMe}_{3}\right)_{3}\right]^{[121 \mathrm{a}]}$ (av $1.935 \AA$ ). The Si-O bond distances are seen in the range of $1.595(4) \AA[\mathrm{Si}(5)-\mathrm{O}(7)]$ to $1.638(4) \AA[\mathrm{Si}(1)-\mathrm{O}(2)]$ with an average value of $1.62(4) \AA$, similar to the reported value found in $\left[\mathrm{RSiO}_{3} \mathrm{Al} \cdot \mathrm{THF}\right]_{4}(\mathrm{R}=(2,6-$ $\left.\left.i \operatorname{Pr}_{2} \mathrm{C}_{6} \mathrm{H}_{3}\right) \mathrm{N}\left(\mathrm{SiMe}_{3}\right)\right) .{ }^{[81 \mathrm{c}]}$ The distortion of the cube is indicated by the broad range of the SbO-Si angles. Thus, the Sb-O-Si angles within the framework are in the range of $128.9(2)^{\circ}$ $[\mathrm{Si}(5)-\mathrm{O}(8)-\mathrm{Sb}(4)]$ to $158.1(2)^{\mathrm{o}}[\mathrm{Si}(13)-\mathrm{O}(20)-\mathrm{Sb}(8)]\left(\mathrm{av} 142.5^{\circ}\right)$

Compound $\mathbf{6}$ is synthesized by the addition of a hexane solution of bismuth(III) amide $^{[130]}$ to a suspension of $\mathrm{RSi}(\mathrm{OH})_{3}\left(\mathrm{R}=\left(2,6-i \mathrm{Pr}_{2} \mathrm{C}_{6} \mathrm{H}_{3}\right) \mathrm{N}\left(\mathrm{SiMe}_{3}\right)\right)(\mathbf{1})$ in 1:1 molar ratio, at room temperature, in about $23 \%$ yield (Scheme 5). The formation of $\mathbf{6}$ is not clear. However, we assume that the formation of $\mathbf{6}$ proceeds with the evolution of dimethylamine gas and a self-condensation of the silanetriol to generate the disiloxanetetrol $\left[\left(\mathrm{RSi}(\mathrm{OH})_{2}\right)_{2} \mathrm{O}\right]$ and water. This process is may be catalyzed by bismuth(III) amide which is based on our earlier observation with hydrazine. ${ }^{[111]}$ Furthermore, during the course of the reaction, two molecules of dimethylamine are eliminated, resulting in the capping of the three Bi(III) centers by the oxygen of an eliminated water molecule. The yield of $\mathbf{6}$ highly depends on the chlorine 
containing bismuth(III) amide. For the preparation of bismuth(III) amide ${ }^{[130]}$ we followed the literature method. However, the bismuth(III) amide in our hands was more or less contaminated with chlorine. Thus, the reaction of $\left[\mathrm{Bi}_{12}\left(\mathrm{O}_{3} \mathrm{SiR}\right)_{8}\left(\mu_{3}-\mathrm{O}\right)_{4} \mathrm{Cl}_{4}(\mathrm{THF})_{8}\right](\mathrm{R}=(2,6-$ $\left.i \mathrm{Pr}_{2} \mathrm{C}_{6} \mathrm{H}_{3}\right) \mathrm{N}\left(\mathrm{SiMe}_{3}\right)$ ) (6) may involve, eight molecules of silanetriol, eight molecules of $\mathrm{Bi}\left(\mathrm{NMe}_{2}\right)_{3}$, four molecules of $\mathrm{Bi}\left(\mathrm{NMe}_{2}\right)_{2} \mathrm{Cl}$, and four molecules of water under elimination of thirty-two molecules of $\mathrm{HNMe}_{2}$.

Compound 6 has been characterized based on their analytical, spectroscopic, and mass spectrometric data. Interestingly, compound 6 does not melt up to $398{ }^{\circ} \mathrm{C}$ and decomposes without melting on further heating. However, no peak attributable to the molecular ion of 6 can be observed in the EI or other mass spectrometric methods. Only smaller fragment ion peaks are found. Similar to compound $\left[\mathrm{Bi}_{22} \mathrm{O}_{26}\left(\mathrm{OSiMe}_{2} t \mathrm{Bu}\right)_{14}\right],{ }^{[122 \mathrm{~d}]}$ compound $\mathbf{6}$ is also good soluble in common hydrocarbon solvents, such as benzene. Like 5, $\mathbf{6}$ also shows the absence of a characteristic strong broad IR absorption centered around $3400 \mathrm{~cm}^{-1}$, indicating that all of the $\mathrm{Si}-\mathrm{OH}$ groups of $\mathbf{1}$ have reacted and the IR spectrum is dominated by the typical M-O-Si stretching frequencies observed in the range of 900 to $1000 \mathrm{~cm}^{-1}$. It is difficult to deduce the structure of compound 6 as its ${ }^{1} \mathrm{H}$ NMR spectrum (in $\mathrm{C}_{6} \mathrm{D}_{6}$ ) revealed several multiple resonances for the methyl ( $\mathrm{SiMe}_{3}$, and $i \mathrm{Pr}$ ), isopropyl $-\mathrm{CH}$, aryl protons, and (slightly broad) coordinated THF molecules protons. Nevertheless, the ${ }^{29}$ Si NMR spectrum of compound 6 (in $\mathrm{C}_{6} \mathrm{D}_{6}$ ) displays the presence of six resonances, out of which the first three are assigned for the $\mathrm{SiMe}_{3} \mathrm{~N}$ unit $(\delta=6.4,5.5,2.5 \mathrm{ppm})$, whereas the rest are assigned for the $\mathrm{SiO}_{3} \mathrm{~N}$ part $(\delta=-$ $72.2,-79.1,-83 \mathrm{ppm})$, indicating that in each $\mathrm{Bi}_{6} \mathrm{Cl}_{2} \mathrm{O}_{14} \mathrm{Si}_{4}$ unit out of four, two silanetriol molecules are present in the same electronic environment. In compounds 5 and $\mathbf{6}$ the ${ }^{29} \mathrm{Si}$ NMR chemical shifts for the $\mathrm{SiO}_{3} \mathrm{~N}$ silicon centers are shifted upfield compared to the values observed in the parent silanetriol $(-67.3 \mathrm{ppm}) .{ }^{[79]}$ The solid state structure of 6 has been unambiguously established by single-crystal X-ray diffraction study. (Figure 11) 


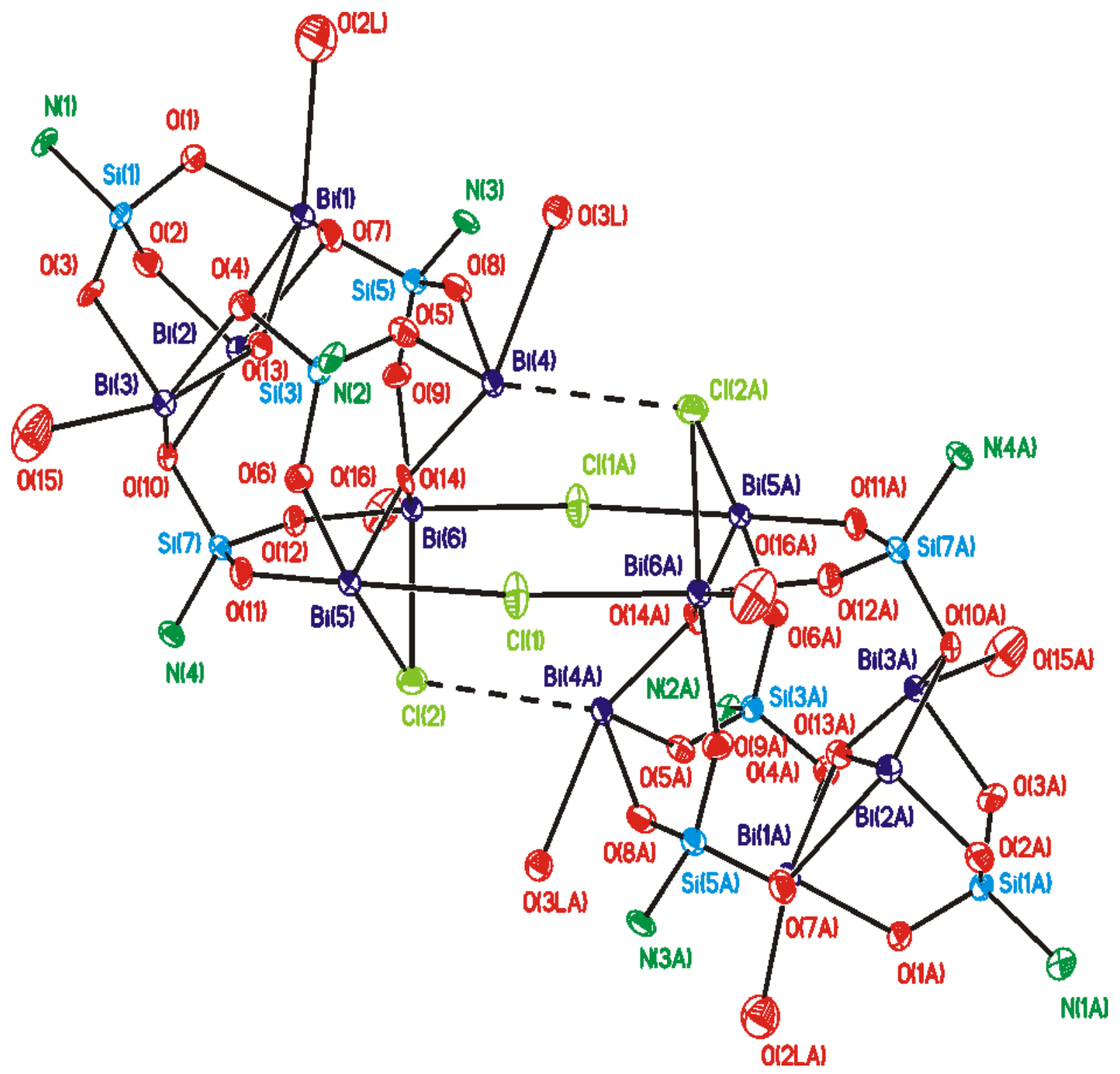

Figure 11. ORTEP diagram of core 6 with $50 \%$ probability. Most of the substituents on silicon and bismuth atoms are omitted for the sake of clarity. Selected bond lengths $[\AA]$ and angles $\left[^{\circ}\right]: \mathrm{Bi}(1)-\mathrm{O}(1) 2.068(5), \mathrm{Bi}(1)-\mathrm{O}(13)$ 2.139(5), $\mathrm{Bi}(1)-\mathrm{O}(7)$ 2.272(5), $\mathrm{Bi}(1)-\mathrm{O}(4)$ 2.476(5), $\mathrm{Bi}(2)-\mathrm{O}(2)$ 2.067(6), $\mathrm{Bi}(2)-\mathrm{O}(13)$ 2.149(5), $\mathrm{Bi}(2)-\mathrm{O}(10)$ 2.245(5), $\mathrm{Bi}(2)-\mathrm{O}(7)$ 2.451(5), $\mathrm{Bi}(3)-\mathrm{O}(3)$ 2.086(5), $\mathrm{Bi}(3)-\mathrm{O}(13)$ 2.155(5), Bi(3)-O(4) 2.307(5), $\mathrm{Bi}(3)-\mathrm{O}(10)$ 2.512(6), $\mathrm{Bi}(3)-\mathrm{O}(15)$ 2.673(7), $\mathrm{Bi}(4)-\mathrm{O}(8)$ 2.084(5), $\mathrm{Bi}(4)-\mathrm{O}(5)$ 2.100(5), $\mathrm{Bi}(4)-\mathrm{O}(14)$ 2.230(5), $\mathrm{Bi}(5)-\mathrm{O}(11)$ 2.115(5), $\mathrm{Bi}(5)-\mathrm{O}(6)$ 2.136(5), $\mathrm{Bi}(5)-\mathrm{O}(14) 2.151(5), \mathrm{Bi}(6)-\mathrm{O}(12)$ 2.102(5), $\mathrm{Bi}(6)-\mathrm{O}(9)$ 2.144(5), $\mathrm{Bi}(6)-\mathrm{O}(14)$ 2.236(5), $\mathrm{Bi}(6)-\mathrm{O}(16) 2.698(6), \mathrm{Bi}(1)-\mathrm{O}(2 \mathrm{~L})$ 2.893(7), $\mathrm{Bi}(4)-\mathrm{O}(3 \mathrm{~L})$ 2.794(5), $\mathrm{Bi}(5)-\mathrm{Cl}(2)$ 2.851(2), $\mathrm{Bi}(5)-\mathrm{Cl}(1)$ 2.966(2), $\mathrm{Bi}(6)-\mathrm{Cl}(2)$ 
2.885(2), $\mathrm{Bi}(6)-\mathrm{Cl}(1 \mathrm{~A}) \quad 3.019(2), \quad \mathrm{Si}(1)-\mathrm{O}(2)$ 1.621(6), $\mathrm{Si}(1)-\mathrm{O}(1)$ 1.626(6), $\mathrm{Si}(1)-\mathrm{O}(3)$ 1.636(6), $\quad \mathrm{Si}(3)-\mathrm{O}(6) \quad 1.621(5), \quad \mathrm{Si}(3)-\mathrm{O}(5)$ 1.633(5), $\quad \mathrm{Si}(3)-\mathrm{O}(4)$ 1.651(5), $\quad \mathrm{Si}(5)-\mathrm{O}(9)$ 1.613(5); O(1)-Bi(1)-O(13) 89.8(2), O(1)-Bi(1)-O(7) 91.4(2), O(13)-Bi(1)-O(7) 71.74(18), $\mathrm{O}(1)-\mathrm{Bi}(1)-\mathrm{O}(4)$ 91.3(2), O(13)-Bi(1)-O(4) 67.71(17), O(2)-Bi(2)-O(13) 89.5(2), O(2)Bi(2)-O(10) 89.5(2), O(13)-Bi(2)-O(10) 72.51(19), O(2)-Bi(2)-O(7) 90.96(19), O(13)Bi(2)-O(7) 68.08(18), O(3)-Bi(3)-O(13) 89.3(2), O(3)-Bi(3)-O(4) 90.9(2), O(13)-Bi(3)$\mathrm{O}(4)$ 70.74(18), O(3)-Bi(3)-O(10) 89.99(18), O(13)-Bi(3)-O(10) 67.21(17), O(3)-Bi(3)$\mathrm{O}(15) \quad 80.4(2), \quad \mathrm{O}(4)-\mathrm{Bi}(3)-\mathrm{O}(15) \quad 98.8(2), \quad \mathrm{O}(8)-\mathrm{Bi}(4)-\mathrm{O}(5) \quad 89.6(2), \quad \mathrm{O}(8)-\mathrm{Bi}(4)-\mathrm{O}(14)$ 89.61(18), O(5)-Bi(4)-O(14) 90.43(19), O(11)-Bi(5)-O(6) 86.2(2), O(11)-Bi(5)-O(14) 93.58(19), $\mathrm{O}(11)-\mathrm{Bi}(5)-\mathrm{Cl}(2)$ 88.86(15), O(11)-Bi(5)-Cl(1) 174.24(15), O(6)-Bi(5)-O(14) 90.46(19), $\mathrm{Cl}(2)-\mathrm{Bi}(6)-\mathrm{Cl}(1 \mathrm{~A})$ 83.95(6), $\mathrm{Bi}(1)-\mathrm{O}(13)-\mathrm{Bi}(2)$ 113.3(2), $\mathrm{Bi}(1)-\mathrm{O}(13)-\mathrm{Bi}(3)$ 114.3(2), $\quad \mathrm{O}(1)-\mathrm{Bi}(1)-\mathrm{O}(2 \mathrm{~L}) \quad 80.4(2), \quad \mathrm{O}(13)-\mathrm{Bi}(1)-\mathrm{O}(2 \mathrm{~L}) \quad 159.9(2), \quad \mathrm{O}(7)-\mathrm{Bi}(1)-\mathrm{O}(2 \mathrm{~L})$ 125.7(2), O(4)-Bi(1)-O(2L) 94.8(2), O(8)-Bi(4)-O(3L) 73.5 (2), O(5)-Bi(4)-O(3L) 76.4(2), $\mathrm{O}(14)-\mathrm{Bi}(4)-\mathrm{O}(3 \mathrm{~L}) 158.4(2)$.

The pale yellow crystals of $\mathbf{6}$ were obtained from a hexane/THF mixture at room temperature over a period of two weeks. The ORTEP diagram of $\mathbf{6}$ is depicted in Figure 11. Compound 6 crystallizes in the monoclinic space group $P 2_{1} / n$ along with half of the molecule and one molecule of THF in the asymmetric unit. Selected bond distances and angles obtained for this compound are listed in Figure 11. The molecular structure of $\mathbf{6}$ consists of a $\mathrm{Bi}_{12} \mathrm{Cl}_{4} \mathrm{O}_{28} \mathrm{Si}_{8}$ core. The core structure of 6 contains two $\mathrm{Bi}_{6} \mathrm{Cl}_{2} \mathrm{O}_{14} \mathrm{Si}_{4}$ units that are fused together to generate a $\mathrm{Bi}_{4} \mathrm{Cl}_{2} \mathrm{O}_{4} \mathrm{Si}_{2}$ [Bi(6)-Cl(1A)- $\mathrm{Bi}(\mathrm{A} 5)-\mathrm{O}(11 \mathrm{~A})-\mathrm{Si}(7 \mathrm{~A})-\mathrm{O}(12 \mathrm{~A})-\mathrm{Bi}(6 \mathrm{~A})-$ $\mathrm{Cl}(1)-\mathrm{Bi}(5)-\mathrm{O}(11)-\mathrm{Si}(7)-\mathrm{O}(12)]$ twelve-membered ring (Figure 11).

Each of these $\mathrm{Bi}_{6} \mathrm{Cl}_{2} \mathrm{O}_{14} \mathrm{Si}_{4}$ units is made up of four-(two $\mathrm{Bi}_{2} \mathrm{O}_{2}$ and one $\mathrm{Bi}_{2} \mathrm{ClO}$ ), six(seven $\mathrm{Bi}_{2} \mathrm{O}_{3} \mathrm{Si}$, one $\mathrm{Bi}_{2} \mathrm{ClO}_{2} \mathrm{Si}$, one $\mathrm{Bi}_{2} \mathrm{ClO}_{2} \mathrm{Si}$ and one $\mathrm{Bi}_{3} \mathrm{O}_{3}$ ) and eight-membered rings (three $\mathrm{Bi}_{2} \mathrm{O}_{4} \mathrm{Si}_{2}$, one $\mathrm{Bi}_{3} \mathrm{O}_{4} \mathrm{Si}$, and one $\mathrm{Bi}_{3} \mathrm{ClO}_{3} \mathrm{Si}$ ). The $\mu_{3}$-bridging oxygens $\mathrm{O}(13)$ and $\mathrm{O}(14)$ 
have markedly pyramidal and distorted trigonal planar geometries, which can be indicated by the sum of the $\mathrm{Bi}-\mathrm{O}-\mathrm{Bi}$ angles centered around $\mathrm{O}(13)\left(\Sigma 342^{\circ}\right)$ and $\mathrm{O}(14)\left(\Sigma 355^{\circ}\right)$ respectively. Interestingly, these $\mu_{3}$-bridging oxygens lead to the formation of four-(two $\mathrm{Bi}_{2} \mathrm{O}_{2}$ $[\mathrm{Bi}(2)-\mathrm{O}(13)-\mathrm{Bi}(1)-\mathrm{O}(7)$; $\mathrm{Bi}(2)-\mathrm{O}(13)-\mathrm{Bi}(3)-\mathrm{O}(10)]$ around $\mathrm{O}(13)$ and one $\mathrm{Bi}_{2} \mathrm{ClO}[\mathrm{Bi}(6)-$ $\mathrm{O}(14)-\mathrm{Bi}(5)-\mathrm{Cl}(2)])$, six-(one $\mathrm{Bi}_{2} \mathrm{O}_{3} \mathrm{Si} \quad[\mathrm{Si}(5)-\mathrm{O}(8)-\mathrm{Bi}(4)-\mathrm{O}(14)-\mathrm{Bi}(6)-\mathrm{O}(9)]$ around $\mathrm{O}(14)$, which are fused together to form another $\left.\mathrm{Bi}_{3} \mathrm{O}_{3}[\mathrm{Bi}(2)-\mathrm{O}(7)-\mathrm{Bi}(1)-\mathrm{O}(13)-\mathrm{Bi}(3)-\mathrm{O}(10)]\right)$ and eight-membered rings $\left(\mathrm{Bi}_{3} \mathrm{ClO}_{3} \mathrm{Si} \quad[\mathrm{Bi}(6)-\mathrm{O}(9)-\mathrm{Si}(5)-\mathrm{O}(8)-\mathrm{Bi}(4)-\mathrm{O}(14)-\mathrm{Bi}(5)-\mathrm{Cl}(2)]\right) . \quad \mathrm{As}$ shown in Figure 11, the coordination geometry at $\mathrm{Bi}(1)$, and $\mathrm{Bi}(3)$ may be described as a distorted square pyramid with two silicon bonded $\mu_{3}$-bridging oxygen atoms, one $\mu_{3}$-bridging oxygen atom, one coordinated oxygen atom of a THF molecule, and a silicon bonded $\mu$ bridging oxygen. The $\mathrm{O}-\mathrm{Bi}-\mathrm{O}$ angles around $\mathrm{Bi}(1)$ and $\mathrm{Bi}(3)$ are in the range of $67.7(2)$ to $159.9(2)^{\circ}$ and $67.2(2)$ to $165.3(2)^{\circ}$ respectively, which deviate slightly from the ideal value of $90^{\circ}$ indicating a stereochemically active lone pair.

The coordination environment of $\mathrm{Bi}(2)$ is composed of three silicon bonded oxygen atoms, and one $\mu_{3}$-bridging oxygen however, the environment around $\mathrm{Bi}(4)$ consists of two silicon bonded oxygens, one $\mu_{3}$-bridging oxygen, and one coordinated oxygen atom of a THF molecule. Both $\mathrm{Bi}(2)$ and $\mathrm{Bi}(4)$ are in a distorted tetrahedral geometry. The O-Bi-O angles around $\mathrm{Bi}(2)$ and $\mathrm{Bi}(4)$ fall in the range of $68.1(2)$ to140.6(2) and 73.5(2) to158.4(2) which are strongly deviate from the ideal tetrahedral values $\left(109.5^{\circ}\right)$. The $\mathrm{Bi}(5)$ adopts a distorted trigonal bipyramidal geometry with one silicon bonded oxygen, one $\mu_{3}$-bridging oxygen, and one chlorine ligand at the equatorial sites and one silicon bonded oxygen, and one chlorine at the apical sites, with an angle of $174.24(2)^{\circ}$. The rest of the angles at $\mathrm{Bi}(5)$ are in the range of (77.8(1) to $\left.166.95(14)^{\circ}\right)$. The coordination environment around $\mathrm{Bi}(6)$ is made up of two silicon bonded oxygens, one $\mu_{3}$-bridging oxygen, one coordinated oxygen of a THF molecule, and two chlorine in a distorted octahedral geometry. The $\mathrm{O}-\mathrm{Bi}-\mathrm{Cl}$ axis is quasi linear $\left(165.6(1)^{\circ}\right)$ 
and the corresponding angles centered around $\mathrm{Bi}(6)$ are in the range from $75.4(2)$ to $163.2(2)^{\circ}$. The O-Si-O angles are within the range of $105.0(3)$ to $113.3(2)^{\circ}$ for $[\mathrm{O}(6)-\mathrm{Si}(3)-\mathrm{O}(4)$ and $\mathrm{O}(11)-\mathrm{Si}(7)-\mathrm{O}(12)$ av $108.5^{\circ}$, indicating the nearly ideal tetrahedral geometry for the silicon atoms.

The Bi-O bond distances in compound 6 vary in the range of 2.067(6) $\AA$ to 2.893(6) $\AA$ for $[\mathrm{Bi}(2)-\mathrm{O}(2)$ and $\mathrm{Bi}(1)-\mathrm{O}(2 \mathrm{~L})]$, with an average value of 2.291(7) $\AA$. The bond lengths involving the $\mu_{3}$ oxygen centers are at the longer end of the range $2.139(5) \AA$ to $2.512(6) \AA$ for $[\mathrm{Bi}(1)-\mathrm{O}(13)$ and $\mathrm{Bi}(3)-\mathrm{O}(10)]$ with an average value of $2.277(6) \AA$, and those to the $\mu$ oxygen centers are the shortest 2.067(6) $\AA$ to $2.144(5) \AA$ for $[\mathrm{Bi}(2)-\mathrm{O}(2)$ and $\mathrm{Bi}(6)-\mathrm{O}(9) \mathrm{av}$ 2.10(6) $\AA$ ]. The average $\mathrm{Bi}-\mathrm{O}$ bond length in the framework is $2.189(6) \AA$ which is remarkably shorter than the exocyclic Bi-O bond distances of 2.765(7) $\AA$. The Si-O and Bi-Cl bond distances fall in the range of 1.613(5) to 1.663(5) $\AA$ for $[\mathrm{Si}(5)-\mathrm{O}(9)$ and $\mathrm{Si}(7)-\mathrm{O}(10)]$ (av 1.632(6) $\AA$ ) and 2.851(2) to 3.019(2) $\AA$ for $[\mathrm{Bi}(5)-\mathrm{Cl}(2)$ and $\mathrm{Bi}(6)-\mathrm{Cl}(1 \mathrm{~A})$ av 2.93(2) $\AA]$ (sum of the atomic radii for $\mathrm{Bi}-\mathrm{Cl} 2.87 \AA),{ }^{[1]}$ respectively. Compared with $\mathrm{Bi}\left(\mathrm{OSiPh}_{3}\right)_{3}(\mathrm{THF})_{3}$, which shows a Bi-O bond distance of av $2.495 \AA$, the average Bi-O distance in 6 is shorter by $0.204 \AA$. These Bi-O bond distances can be compared to those reported Bi-O bond distances $\left\{\right.$ av 2.165(16) $\AA$ for $\left.\left[\left(\mathrm{Bu} t \mathrm{PO}_{3} \mathrm{H}\right)_{10}\left(\mathrm{Bu} t \mathrm{PO}_{3} \mathrm{H}\right)_{2} \mathrm{Bi}_{14} \mathrm{O}_{10} \cdot 3 \mathrm{C}_{6} \mathrm{H}_{6} \cdot 4 \mathrm{H}_{2} \mathrm{O}\right]\right\},{ }^{[122 \mathrm{~b}]}\{$ av 2.348(9) $\AA$ for $\left.\mathrm{Bi}_{8}\left(\mu_{4}-\mathrm{O}\right)_{2}\left(\mu_{3}-\mathrm{O}\right)_{2}(\mu-\mathrm{OR}) \quad\left(\mathrm{R}=\mathrm{OC}_{6} \mathrm{~F}_{5}\right)\right\},{ }^{[122 \mathrm{c}]} \quad$ and $\quad\{(\mathrm{av} \quad 2.346(11) \quad \AA) \quad$ for $\left.\left[\mathrm{Bi}_{22} \mathrm{O}_{26}\left(\mathrm{OSiMe}_{2} t \mathrm{Bu}\right)_{14}\right]\right\} .{ }^{[122 \mathrm{~d}]}$

Therefore, the single crystal X-ray structure analysis of the first cubic polyhedral antimony(III) containing siloxane $\mathbf{5}$ is reported. Compound $\mathbf{6}$ represents an extremely soluble new bismuth(III) cluster containing chlorine and siloxane ligands. In both of these compounds antimony and bismuth atoms are in the formal oxidation state of + III with the $\mathrm{M} / \mathrm{Si}$ ratio of 4:4 and 12:8, respectively. 


\subsection{First Examples of Polyhedral Ferric Siloxanes}

Iron is the fourth most abundant element in the earth's crust after oxygen, silicon and aluminum. Although iron is present in one of its ores, hematite $\left(\mathrm{Fe}_{2} \mathrm{O}_{3}\right)$, in the formal oxidation state + III, in magnetite $\left(\mathrm{Fe}_{3} \mathrm{O}_{4}\right)$, it exhibits both the oxidation states + II and + III. In the naturally occurring olivine, $\mathrm{MgFeSiO}_{4}$, it is present in the oxidation state $+\mathrm{II}$ while in garnets, $\left[\mathrm{M}^{2+}{ }_{3} \mathrm{M}^{3+}{ }_{2}\left(\mathrm{SiO}_{4}\right)_{3}\right]\left[\mathrm{M}^{2+}=\mathrm{Co}, \mathrm{Mg}, \mathrm{Fe} ; \mathrm{M}^{3+}=\mathrm{Al}, \mathrm{Cr}, \mathrm{Fe}\right)$ it is found in both oxidation states. ${ }^{[1,131]}$ Other examples of iron containing silicate frame works include zeolites such as Fe-modified ZSM-5, which have been shown to be important as catalysts, as for example in the synthesis of phenol from benzene and $\mathrm{N}_{2} \mathrm{O} .{ }^{[132]}$ Moreover the Lewis acidity of the iron centers in Fe-modified ZSM-5 enables its utility as an acid catalyst in the benzylation reaction of benzene using benzyl chloride ${ }^{[133]}$ and also in the esterification of tert-butanol by acetic anhydride. ${ }^{[134]}$

In view of the catalytic chemistry of frame-work and extra framework (ion-exchanged) metal-ion substituted zeolites, we were interested in the development of soluble analogous of iron silicates. Thus, we have focused our attention on the synthesis and characterization of iron siloxane frame works. In general, previous work on iron siloxanes mainly centered around the use of $\mathrm{R}_{3} \mathrm{SiO}^{[135]}$ or silsesquioxane ligands. ${ }^{[136]}$ We have overcome this synthetic hurdle by the choice of tris-amido derivative of iron ${ }^{[137]}$ as the starting precursor and has been able to assemble a iron siloxane containing iron in the formal oxidation state of + III. We report herein the synthesis and single crystal X-ray structure of ferric siloxane $\left[\left(\mathrm{L}^{1} \mathrm{Fe}\right)\left(\mathrm{O}_{3} \mathrm{SiR}\right)\right]_{4}\left[\mathrm{~L}^{1}=\mathrm{PMe}_{3} ; \mathrm{R}=\left(2,6-i \mathrm{Pr}_{2} \mathrm{C}_{6} \mathrm{H}_{3}\right) \mathrm{N}\left(\mathrm{SiMe}_{3}\right)\right]$ (7) (Scheme 6). 


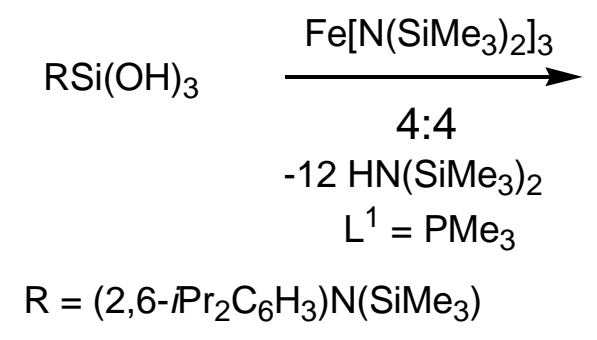

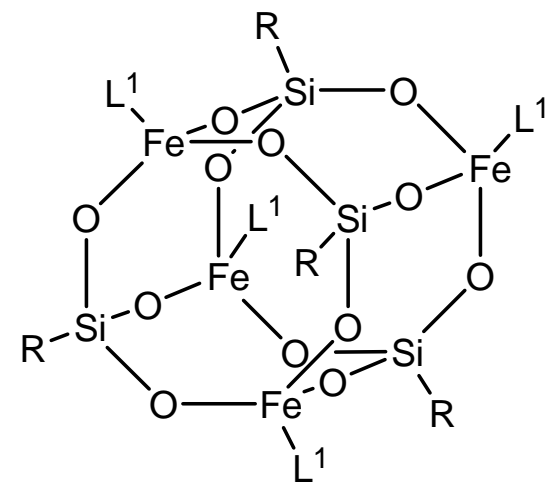

7

Scheme 6: Synthesis of ferric siloxane 7.

The reaction of the silanetriol with the ferric amide $\mathrm{Fe}\left[\mathrm{N}\left(\mathrm{SiMe}_{3}\right)_{2}\right]_{3}{ }^{[137]}$ proceeds with complete elimination of $\mathrm{HN}\left(\mathrm{SiMe}_{3}\right)_{2}$ to afford the ferric siloxane 7 which was crystallized in the presence of trimethyl phosphine $\mathrm{L}^{1}$ (Scheme 7). Compound 7 is highly lipophilic and is soluble in common organic solvents including hexane. The ferric siloxane 7 is thermally stable up to its melting point $\left(242-244^{\circ} \mathrm{C}\right)$. The ESI-MS of 7 shows the base peak for $\left[M^{+}-\right.$ $\mathrm{PMe}_{3}$ ], suggesting the remarkable stability of the core structure of 7 under these conditions. Compound 7 exhibits broad resonances in its NMR spectra indicating that it is paramagnetic.

The molecular structure of 7 is made up of a $\mathrm{Fe}_{4} \mathrm{O}_{12} \mathrm{Si}_{4}$ cuboid core where the corners of the cube are alternately occupied by iron and silicon atoms. Each of the twelve edges of the cube contain the bridging oxygen atoms. Thus, the over-all core structure of the ferric siloxane contains six $\mathrm{Fe}_{2} \mathrm{O}_{4} \mathrm{Si}_{2}$ eight-membered rings as the faces of the cube. Unlike in the ferrous siloxane $\left[\left(\mathrm{RSiO}_{3}\right)_{2}\left(\mathrm{RSi}(\mathrm{OH}) \mathrm{O}_{2}\right)_{4}\left(\mu_{3}-\mathrm{OH}\right)_{2} \mathrm{Fe}_{8}(\mathrm{THF})_{4}\right]\left(\mathrm{R}=\left(2,6-i \mathrm{Pr}_{2} \mathrm{C}_{6} \mathrm{H}_{3}\right) \mathrm{N}\left(\mathrm{SiMe}_{3}\right)\right)$ (9), in compound 7 all the oxygen atoms are involved in a $\mu$ bridging mode interconnecting a silicon and an iron atom. Each iron is tetra-coordinate with a $\mathrm{O}_{3} \mathrm{P}$ coordination environment. The coordination geometry around both iron and silicon centers is nearly tetrahedral. The average Fe-O distance (1.824 $\AA$ ) found in the ferric siloxane 7 is much shorter, due to the smaller ionic radius of $\mathrm{Fe}(\mathrm{III})$ compared to that of $\mathrm{Fe}(\mathrm{II})$ in $\left[\left(\mathrm{RSiO}_{3}\right)_{2}\left(\mathrm{RSi}(\mathrm{OH}) \mathrm{O}_{2}\right)_{4}\left(\mu_{3^{-}}\right.\right.$ 
$\left.\mathrm{OH})_{2} \mathrm{Fe}_{8}(\mathrm{THF})_{4}\right]\left(\mathrm{R}=\left(2,6-i \mathrm{Pr}_{2} \mathrm{C}_{6} \mathrm{H}_{3}\right) \mathrm{N}\left(\mathrm{SiMe}_{3}\right)\right)$ (9). In contrast the Si-O distance in 7 is similar (av. $1.618 \AA$ ) to that found in 9.

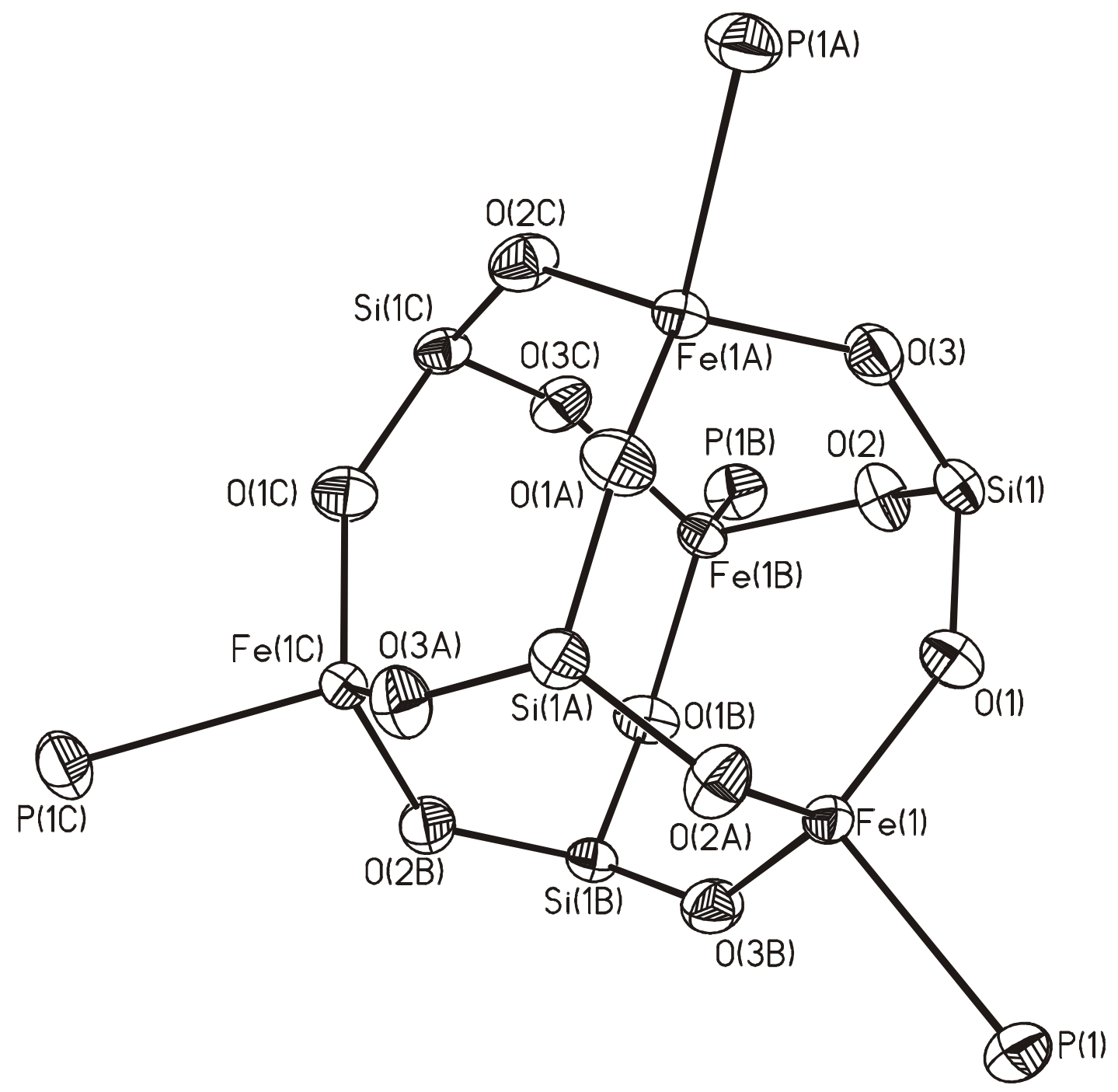

Figure 12. Core structure of 7. The substituents on silanetriol and the phosphane have been omitted for the sake of clarity. Selected bond lengths $[\AA]$ and angles $\left[^{\circ}\right]$ : $\operatorname{Fe}(1)-\mathrm{O}(1) 1.802(3)$, $\mathrm{Fe}(1)-\mathrm{O}(3 \mathrm{~B})$ 1.829(3), Fe(1)-O(2A) 1.831(3), Fe(1)-P(1) 2.468(1), Si(1)-O(1) 1.628(3), Si(1)$\mathrm{O}(2) \quad 1.616(3), \quad \mathrm{Si}(1)-\mathrm{O}(3) \quad 1.612(3) ; \quad \mathrm{Si}(1)-\mathrm{O}(1)-\mathrm{Fe}(1) \quad 147.60(19), \quad \mathrm{O}(1)-\mathrm{Fe}(1)-\mathrm{O}(3 \mathrm{~B})$ 114.61(14), O(3)-Si(1)-O(2) 111.40(16), O(2)-Si(1)-O(1) 108.73(17).

Magnetic properties : Magnetic susceptibility measurements for compound 7 was carried out in two different magnetic fields $(2000 \mathrm{G}$ and $5000 \mathrm{G})$, in the temperature range from 295 to $2.0 \mathrm{~K}$. There was no significant field dependence of the magnetic data observed. Plot of the magnetic moment $\left(\mu_{\mathrm{eff}} / \mu_{\mathrm{B}}\right)$ versus temperature $(T / \mathrm{K})$ at $5000 \mathrm{G}$ is depicted in 
Figure 13. At room temperature the $\mu_{\text {eff }}$ value is $9.83 \mu_{\mathrm{B}}$, that is lower than the value expected for four uncoupled iron(III) centers $\left(\mu_{\mathrm{eff}}=11.83 \mu_{\mathrm{B}}\right.$ for $\left.g=2\right)$. Figure 13 shows that $\mu_{\mathrm{eff}}$ decreases when the temperature is lowered. This is indicative of significant antiferromagnetic exchange coupling within the $\mathrm{Fe}_{4}$ core. The $\mu_{\mathrm{eff}}$ value tend towards $1.7 \mu_{\mathrm{B}}$ at low temperature, in accordance with dominant antiferromagnetic exchange interactions.

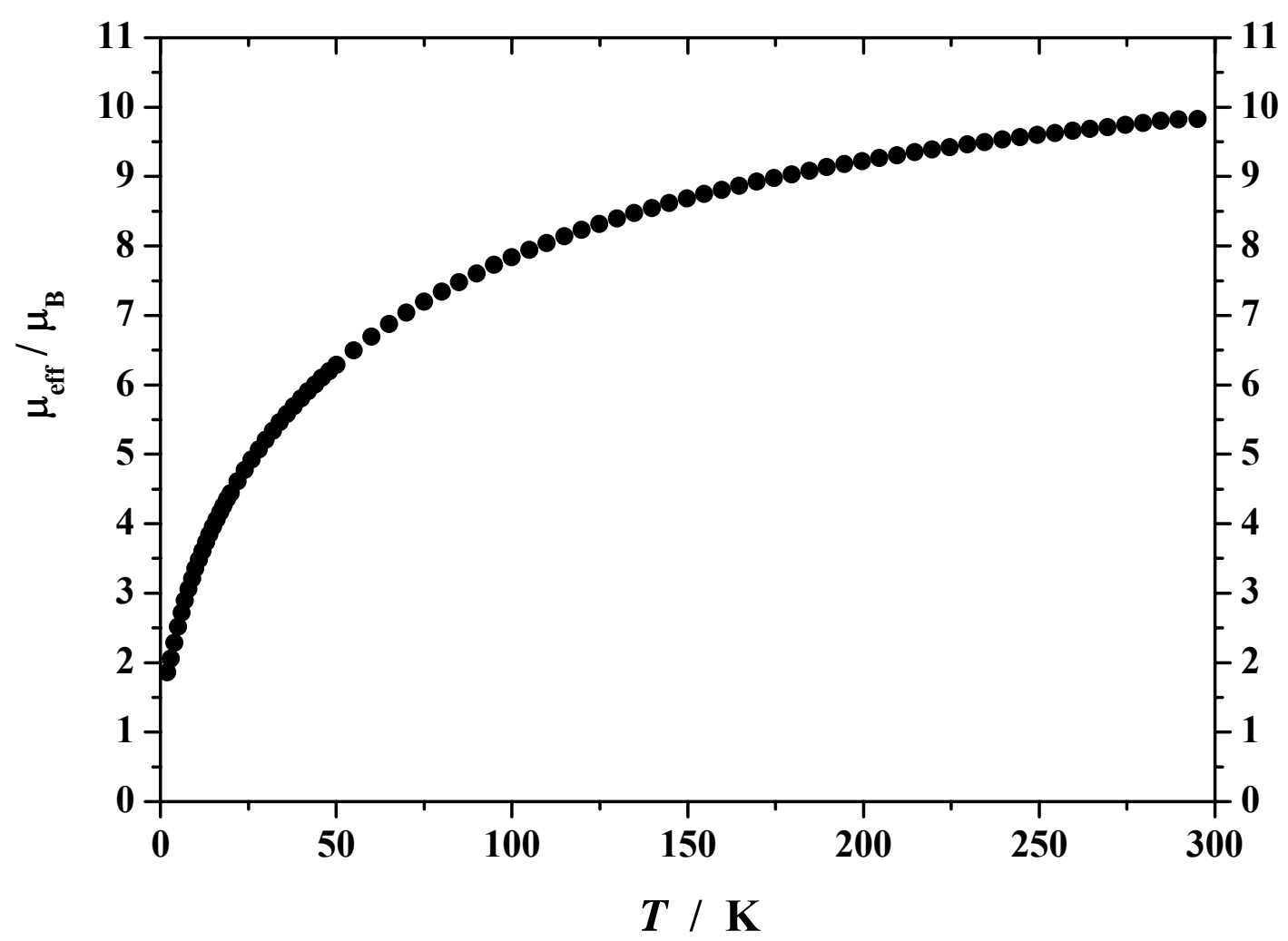

Figure 13. Plot of $\mu_{\mathrm{eff}}\left(\mu_{\mathrm{B}}\right)$ versus $T(\mathrm{~K})$ for compound 7.

In conclusion, we have reported the first examples of polyhedral ferric siloxanes. The isolation of this compound suggested that similar synthetic strategie will allow the preparation of other transition metal siloxane frameworks and this perspective may lead to new interesting systems. 


\subsection{Polyhedral Cobalt(II) and Iron(II) Siloxanes: Synthesis and X-ray}

\section{Crystal Structure of $\left[\left(\mathrm{RSi}(\mathrm{OH}) \mathrm{O}_{2}\right) \mathrm{Co}\left(\mathrm{OPMe}_{3}\right)\right]_{4}$ and \\ $\left[\left(\mathrm{RSiO}_{3}\right)_{2}\left(\mathrm{RSi}(\mathrm{OH}) \mathrm{O}_{2}\right)_{4}\left(\mu_{3}-\mathrm{OH}\right)_{2} \mathrm{Fe}_{8}(\mathrm{THF})_{4}\right]\left(\mathrm{R}=\left(2,6-\mathrm{PPr}_{2} \mathrm{C}_{6} \mathrm{H}_{3}\right) \mathrm{N}\left(\mathrm{SiMe}_{3}\right)\right)$}

The various metal silicates are built up from Si-O-M functional group $(\mathrm{M}=$ main group or transition metal) units. The presence of metal in the siloxane framework not only makes these compounds thermally stable but also improves their catalytic and conducting properties. Many industrially and commercially important processes are catalyzed by transition metal complexes immobilized on silica surfaces. ${ }^{[138]}$ For example cobalt and iron containing silicate frameworks include zeolites such as Co-ZSM-5 and Fe-modified ZSM-5. The Co-ZSM-5 type catalysts have been found to possess a high activity and selectivity for NO decomposition in the presence of hydrocarbons, whereas the Fe-modified ZSM-5 has been important in the synthesis of phenol from benzene and $\mathrm{N}_{2} \mathrm{O} \cdot{ }^{[132,139]}$ Nevertheless, due to the heterogeneous nature of the catalysts the catalytic species are normally difficult to characterize and the exact reactions occurring at such surfaces are remaining unclear. In these cases lipophilic metallasiloxanes may serve as useful models for silica-supported transition metal catalysts. ${ }^{[75,140]}$ Metallasiloxanes have also been envisaged as single-source precursors for modified zeolites. ${ }^{[141]}$ More recently, some of these metallasiloxanes have also been found to be useful in homogeneous catalysis reactions such as $\left[\mathrm{RSiO}_{3} \mathrm{TiOR}^{1}\right]_{4}[\mathrm{R}=(2,6-$ $\left.\left.i \mathrm{Pr}_{2} \mathrm{C}_{6} \mathrm{H}_{3}\right) \mathrm{N}\left(\mathrm{SiMe}_{3}\right)\right]\left[\mathrm{R}^{1}=(\mathrm{Et}, i \mathrm{Pr})\right]$ for the epoxidation of olefins. ${ }^{[86,87]}$

In previous papers we reported the synthesis and single crystal X-ray structures of zinc $\left[\left(\mathrm{RSi}(\mathrm{OH}) \mathrm{O}_{2}\right) \mathrm{Zn}(\mathrm{THF})\right]_{4}{ }^{[84]}$ and ferrous siloxanes $\left[\left\{\left(\mathrm{Me}_{3} \mathrm{Si}\right)_{2} \mathrm{NFe}\right\}_{2}\{\mathrm{LFe}\}_{2}\left\{\mathrm{O}_{3} \mathrm{SiR}\right\}_{2}\right]^{[142]}(\mathrm{L}=$ 1,3-diisopropyl-4,5-dimethylimidazol-2-ylidene) using metal alkyl/amide complexes with kinetically stable aminosilanetriol. As a part of our continuing study of low-coordinate transition metal siloxanes, this report describes the synthesis and X-ray crystal structures of 
$\left[\left(\mathrm{RSi}(\mathrm{OH}) \mathrm{O}_{2}\right) \mathrm{Co}\left(\mathrm{OPMe}_{3}\right)\right]_{4}(\mathbf{8})$ and $\left[\left(\mathrm{RSiO}_{3}\right)_{2}\left(\mathrm{RSi}(\mathrm{OH}) \mathrm{O}_{2}\right)_{4}\left(\mu_{3}-\mathrm{OH}\right)_{2} \mathrm{Fe}_{8}(\mathrm{THF})_{4}\right]$ (9) $(\mathrm{R}=$ (2,6-i $\left.\left.\mathrm{Pr}_{2} \mathrm{C}_{6} \mathrm{H}_{3}\right) \mathrm{N}\left(\mathrm{SiMe}_{3}\right)\right)$. Compound 8 represents the first example of a tetracobalt(II)drum containing siloxane ligands. Previously several methods were reported for the synthesis of Cobalt(II) ${ }^{[143]}$ and Iron(II $)^{[136,144]}$ siloxanes starting from $\mathrm{R}_{3} \mathrm{SiO}$ or silsesquioxane ligands.

The addition of $\mathrm{Co}\left[\mathrm{N}\left(\mathrm{SiMe}_{3}\right)_{2}\right]_{2}$ in hexane to a suspension of $\mathrm{RSi}(\mathrm{OH})_{3}$ (1) in $\mathrm{THF} /$ hexane mixture at room temperature in the presence of trimethylphosphine oxide $\mathrm{L}$ affords 8 in moderate yield (Scheme 7). The reaction proceeds by elimination of eight molecules of $\mathrm{HN}\left(\mathrm{SiMe}_{3}\right)_{2}$ with a concomitant $\mathrm{Co}-\mathrm{O}-\mathrm{Si}$ bond formation containing an unreacted $\mathrm{OH}$ group on each silicon atom. The use of the auxiliary coordinating ligand $\mathrm{L}$ allowed the isolation of the cobalt(II) siloxane $\mathbf{8}$ as a crystalline product. Compound $\mathbf{8}$ is highly soluble in common organic solvents. 8 has been unambiguously characterized by means of analytical, spectroscopic, and single-crystal diffraction studies. The pure crystalline solid of $\mathbf{8}$ is thermally quite stable up to its melting point $196-198{ }^{\circ} \mathrm{C}$, after which its color slowly turns to brown upon decomposition. However, no peak attributable to the molecular ion of $\mathbf{8}$ can be observed in the EI or other mass spectrometric methods. Only smaller fragment ion peaks are found. The IR spectrum exhibited a weak absorption at $3381 \mathrm{~cm}^{-1}$ which is comparable with that of the $\mathrm{OH}$ stretching frequency of the silanol groups $\left(3344 \mathrm{~cm}^{-}\right.$ $\left.{ }^{1}\right) .{ }^{[79]}$ The IR spectra of 8 and $\mathbf{9}$ are dominated by the typical M-O-Si stretching frequencies observed in the range of 900 to $1000 \mathrm{~cm}^{-1}$. 


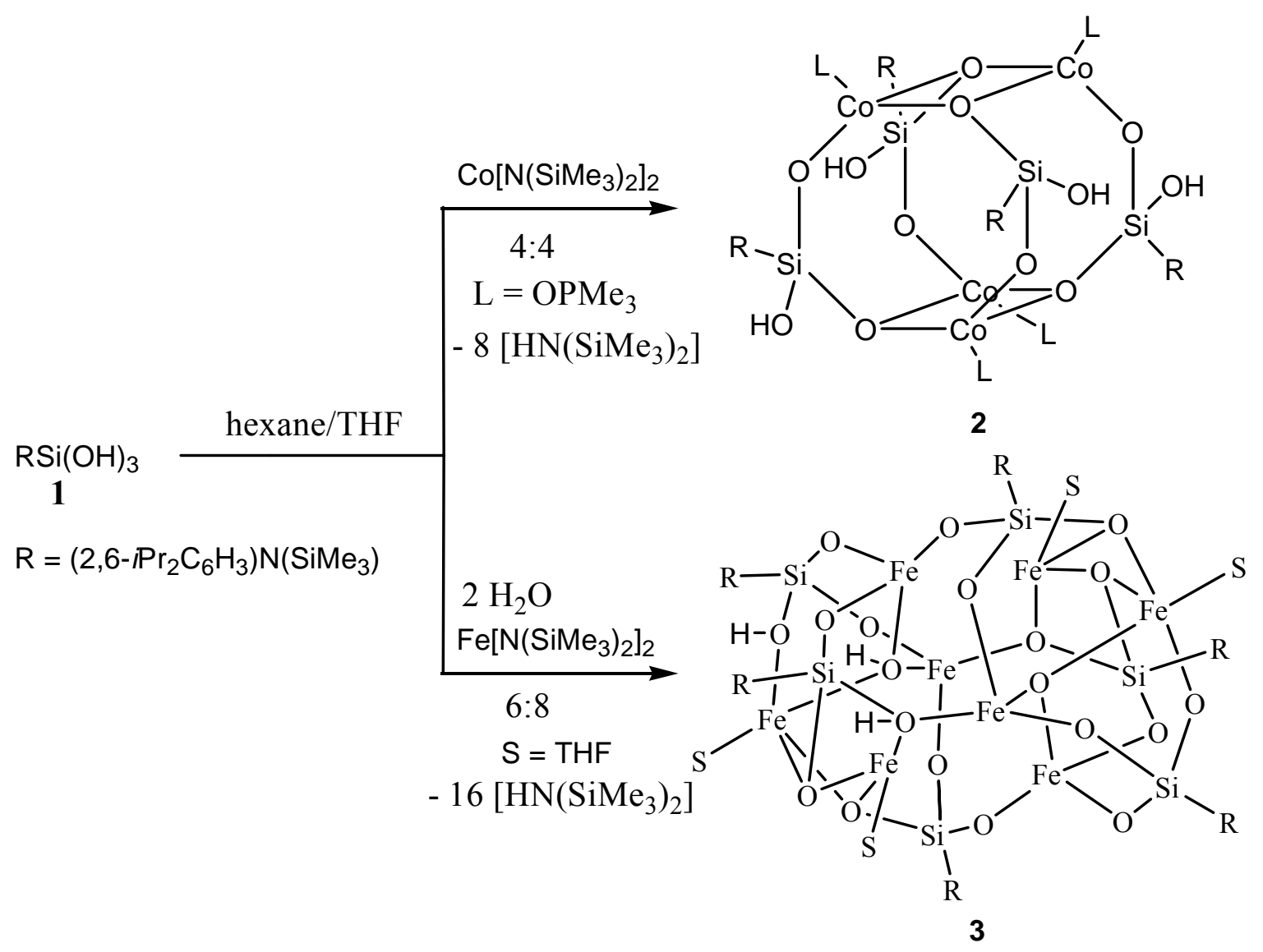

Scheme 7

The blue color crystals of $\mathbf{8}$ were obtained by slow cooling of its saturated solution in toluene and THF at room temperature over a period of two weeks. Compound $\mathbf{8}$ crystallizes in the monoclinic space group $P 2_{1} / c$, with two molecules in the asymmetric unit. Selected metric parameters of $\mathbf{8}$ are summarised in Figure 14. The core structure of $\mathbf{8}$ is given in Figure 14. The molecular structure of $\mathbf{8}$ can be described as a polyhedral hetero-cubane-like architecture with a pseudo 4-fold $\left(S_{4}\right)$ symmetry. The core structure consists of four cobalt, four silicon, and eight oxygen atoms. Importantly, every silicon atom has one unreactive $\mathrm{Si}-\mathrm{OH}$ group. The $\mathrm{Co}_{4} \mathrm{O}_{8} \mathrm{Si}_{4}$ core is surrounded by eight bridging oxo ligands, four double bridging $(\mu-\mathrm{O})$ and four triply bridged $\left(\mu_{3}-\mathrm{O}\right)$ oxygen atoms. An alternative way of viewing compound $\mathbf{8}$ is that it contains two puckered $\mathrm{Co}_{2} \mathrm{O}_{4} \mathrm{Si}_{2}[\mathrm{Co}(1)-\mathrm{O}(31)-\mathrm{Si}(3)-\mathrm{O}(33)-\mathrm{Co}(4)-\mathrm{O}(12)-\mathrm{Si}(1)-\mathrm{O}(13)$, $\mathrm{Co}(2)-\mathrm{O}(43)-\mathrm{Si}(4)-\mathrm{O}(42)-\mathrm{Co}(3)-\mathrm{O}(21)-\mathrm{Si}(2)-\mathrm{O}(23)]$ boat like eight-membered rings that are fused together by four $\mathrm{Co}-\mathrm{O}[\mathrm{Co}(1)-\mathrm{O}(42), \mathrm{Co}(2)-\mathrm{O}(33), \mathrm{Co}(3)-\mathrm{O}(13), \mathrm{Co}(4)-\mathrm{O}(23)]$ bonds. 
Interestingly, this arrangement leads to the formation of two almost planar four-membered $\mathrm{Co}_{2} \mathrm{O}_{2}$ rings $[\mathrm{Co}(1)-\mathrm{O}(42)-\mathrm{Co}(3)-\mathrm{O}(13), \mathrm{Co}(2)-\mathrm{O}(23)-\mathrm{Co}(4)-\mathrm{O}(33)]$, and the cobalt atoms of one ring are connected with the oxygens of the second one.

Each cobalt is tetra-coordinate with its coordination environment made up of only oxygen atoms, in which $\mathrm{OPMe}_{3}$ takes up the fourth coordination side. The coordination geometry around both the cobalt and the silicon centers is nearly tetrahedral. The shortest Co$\mathrm{O}$ and Si-O distances are seen for $\mathrm{Co}(1)-\mathrm{O}(31)[1.937(8) \AA]$ and $\mathrm{Si}(2)-\mathrm{O}(21)$ bonds $[1.600(8)$ $\AA]$ while the longest distances are observed for $\mathrm{Co}(1)-\mathrm{O}(42)[2.016(9) \AA]$ and $\mathrm{Si}(1)-\mathrm{O}(11)$ bonds $[1.640(9) \AA]$, respectively. The bond lengths involving the $\mu_{3}$ oxygen centers are found to be longer $\{\mathrm{Co}(1)-\mathrm{O}(42)[2.016(9) \AA], \mathrm{Co}(2)-\mathrm{O}(23)[2.013(8) \AA], \mathrm{Co}(3)-\mathrm{O}(13)[2.011(9)$ $\AA], \mathrm{Co}(4)-\mathrm{O}(33)[1.988(8) \AA]\}$ than the corresponding distances involving the $\mu$ oxygens $\{\mathrm{Co}(1)-\mathrm{O}(31)[1.937(8) \AA], \mathrm{Co}(2)-\mathrm{O}(43)$ [1.944(8) $\AA], \mathrm{Co}(3)-\mathrm{O}(21)[1.938(8) \AA], \mathrm{Co}(4)-$ $\mathrm{O}(12)[1.967(8) \AA]\}$. A similar range of bond distances was also observed in the case of other cobalt(II) siloxanes that have been reported earlier. Thus, in $\left[\left\{\mathrm{Co}_{3}\left(p^{-}-t-\right.\right.\right.$ butylcalix[4]areneOSiMe $\left.\left.)_{2}(\mathrm{THF})\right\} \cdot 5 \mathrm{PhMe}\right],^{[143 \mathrm{a}]} \quad\left[\left\{\mathrm{Co}\left(\mathrm{OSiPh}_{3}\right)_{2}(\mathrm{THF})\right\}_{2}\right]^{[143 \mathrm{~b}]} \quad$ and $\left[\left\{\left(\left(\mathrm{Me}_{3} \mathrm{Si}\right)_{3} \mathrm{SiO}\right)_{2} \mathrm{Co}_{2}\right]^{[135 \mathrm{~d}]}\right.$ which contains a four-membered $\mathrm{Co}_{2} \mathrm{O}_{2}$ ring with the av Co-O bond distance 1.985(1) $\AA, 1.988(3) \AA$, and 1.952(8) $\AA$, respectively. The O-Co-O bond angles within the $\mathrm{Co}_{2} \mathrm{O}_{2}$ rings are around $90^{\circ}$ and reveal the almost perfect rectangular geometry of the four-membered rings. The $\operatorname{Co}(1)-\operatorname{Co}(3)$ and $\operatorname{Co}(2)-\operatorname{Co}(4)$ distances 2.890(3) $\AA$ and $2.889(3) \AA$, are also very close to the reported ones. ${ }^{[143 a]}$ 


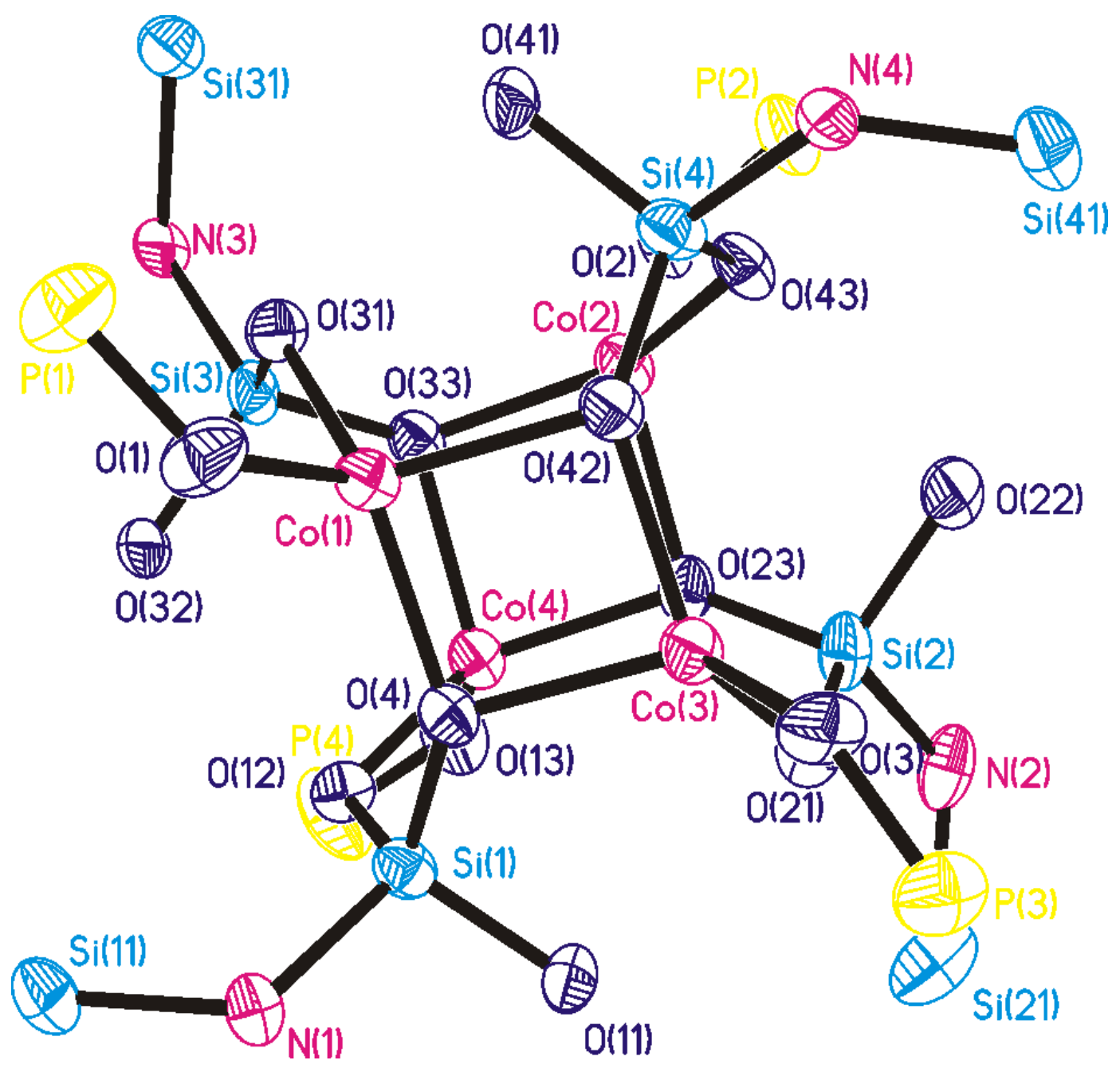

Figure 14. ORTEP diagram of core 2 with $50 \%$ probability. Most of the substituents on silicon and cobalt atoms are omitted for the sake of clarity. Selected bond lengths $[\AA]$ and angles[ $\left[^{\circ}\right]: \operatorname{Co}(1)-\mathrm{O}(13)$ 1.967(8), $\mathrm{Co}(1)-\mathrm{O}(31)$ 1.937(8), $\mathrm{Co}(2)-\mathrm{O}(33)$ 1.961(9), $\mathrm{Co}(2)-\mathrm{O}(43)$ 1.944(8), $\mathrm{Co}(1)-\mathrm{Co}(3)$ 2.890(3), $\mathrm{Si}(1)-\mathrm{O}(11)$ 1.640(9), $\mathrm{Si}(1)-\mathrm{O}(13)$ 1.624(9), $\mathrm{Si}(2)-\mathrm{O}(22)$ 1.632(9), $\mathrm{Si}(3)-\mathrm{O}(32)$ 1.636(9), $\mathrm{Co}(1)-\mathrm{O}(42) \quad 2.016(9), \mathrm{Co}(1)-\mathrm{O}(1)$ 1.959(8), $\mathrm{Co}(2)-\mathrm{O}(23)$ 2.013(8), $\mathrm{Co}(2)-\mathrm{O}(2)$ 1.969(8) $\mathrm{Co}(2)-\mathrm{Co}(4)$ 2.889(3), $\mathrm{Si}(1)-\mathrm{O}(12)$ 1.605(8), $\mathrm{Si}(2)-\mathrm{O}(21)$ 1.600(8), $\mathrm{Si}(2)-\mathrm{O}(23)$ 1.632(9), $\mathrm{Si}(4)-\mathrm{O}(41)$ 1.622(9); O(13)-Co(1)-O(42) 87.2(3), O(31)Co(1)-O(42) 106.9(3), O(33)-Co(2)-O(23) 86.3(3), O(43)-Co(2)-O(23) 106.9(3), O(12)-Si(1)$\mathrm{O}(13), 109.8(4), \mathrm{O}(13)-\mathrm{Si}(1)-\mathrm{O}(11)$ 106.5(4), O(21)-Si(2)-O(22) 112.2(5), O(1)-Co(1)-O(42) 117.9(4), $\quad \mathrm{O}(1)-\mathrm{Co}(1)-\mathrm{O}(13) \quad 111.3(3), \quad \mathrm{O}(33)-\mathrm{Co}(2)-\mathrm{O}(2) \quad 108.3(4), \quad \mathrm{O}(2)-\mathrm{Co}(2)-\mathrm{O}(23)$ 
118.6(3), $\quad \mathrm{O}(12)-\mathrm{Si}(1)-\mathrm{O}(11) \quad 113.7(4), \quad \mathrm{O}(21)-\mathrm{Si}(2)-\mathrm{O}(23) \quad 109.6(5), \quad \mathrm{O}(23)-\mathrm{Si}(2)-\mathrm{O}(22)$ 106.3(5).

The reaction of $\mathrm{Fe}\left[\mathrm{N}\left(\mathrm{SiMe}_{3}\right)_{2}\right]_{2}$ with the $\mathrm{N}$-bonded silanetriol $\mathrm{RSi}(\mathrm{OH})_{3}(\mathbf{1})$ in a $6: 8$ stoichiometric ratio affords the polyhedral octanuclear iron(II)siloxane 9 in $24 \%$ yield (Scheme 7). The isolation of the crystalline product can be achieved in the presence of a Lewis base such as THF. During the course of the reaction a part of silanetriol undergoes selfcondensation to generate the disiloxanetetrol $\left[\left(\mathrm{RSi}(\mathrm{OH})_{2}\right)_{2} \mathrm{O}\right]$ and water. This self condensation is not unusual in view of our previous observation with hydrazine. ${ }^{[120]}$ Herein, the $\mathrm{Fe}(\mathrm{II})$ amide may be equivalent to the properties of hydrazine. The formation of compound 9 is still questionable. We assume that in the presence of $\mathrm{Fe}\left[\mathrm{N}\left(\mathrm{SiMe}_{3}\right)_{2}\right]_{2}$ the $\mathrm{OH}$ group of water is coordinated to three Fe(II) centers by loss of one molecule of $\mathrm{HN}\left(\mathrm{SiMe}_{3}\right)_{2}$. Thus, the overall reaction may have taken place among six molecules of silanetriol, eight molecules of $\mathrm{Fe}\left[\mathrm{N}\left(\mathrm{SiMe}_{3}\right)_{2}\right]_{2}$, and two molecules of water which leads to the formation of $\left[\left(\mathrm{RSiO}_{3}\right)_{2}\left(\mathrm{RSi}(\mathrm{OH}) \mathrm{O}_{2}\right)_{4}\left(\mu_{3}-\mathrm{OH}\right)_{2} \mathrm{Fe}_{8}(\mathrm{THF})_{4}\right]\left(\mathrm{R}=\left(2,6-i \mathrm{Pr}_{2} \mathrm{C}_{6} \mathrm{H}_{3}\right) \mathrm{N}\left(\mathrm{SiMe}_{3}\right)\right)$ (9) by loss of sixteen molecules of $\mathrm{HN}\left(\mathrm{SiMe}_{3}\right)_{2}$. Therefore, compound 9 contains an unreacted $\mathrm{OH}$ group on four silanetriol molecules, and two $\mathrm{OH}$ groups are trapped by three $\mathrm{Fe}(\mathrm{II})$ centers.

Albeit the above statement is consistent with the stoichiometry of the reactants, we were not able to resolve the hydroxyl protons in the molecular structure of 9 . The formation of 9 is insensitive to the slight variations of reactant stoichiometry. Thus, the equimolar quantity of the reactants also leads to the same product formation of 9. A remarkable feature of the $\mathrm{Fe}(\mathrm{II})$ siloxane 9 is its high thermal stability. It is stable up to its melting point of $210-212{ }^{\circ} \mathrm{C}$ at which the color of the compound turns into reddish-brown. Moreover, no peak attributable to the molecular ion of $\mathbf{9}$ can be observed in the EI or other mass spectrometric methods. Compound 9, like 8 discussed above is highly lipophilic and is soluble in various organic solvents such as benzene, toluene, and THF. Compounds $\mathbf{8}$ and $\mathbf{9}$ are paramagnetic and give broad resonances in the NMR spectra. $\mathrm{OH}$ stretching vibrations are observed at 3652 and 
$3265 \mathrm{~cm}^{-1}$ in the IR spectrum of 9. An analogous $\mathrm{OH}$ group absorption was observed in a titanium silicate. ${ }^{[145]}$

Single crystals of 9 suitable for X-ray structural analysis were obtained from a mixture of toluene and THF at $-26{ }^{\circ} \mathrm{C}$ over a period of two weeks. Compound 9 crystallizes in the triclinic space group $P_{1}^{\overline{1}}$, along with six molecules of toluene in the asymmetric unit. Selected metric parameters of 9 are given in Figure 15. As poor quality single crystal were obtained for compounds $\mathbf{8}$ and $\mathbf{9}$, only weak intensity data were obtained during data collection by X-ray irradiation. Therefore the structural analysis is of poor quality (Table CD8). The molecular structure of 9 is made up of a $\mathrm{Fe}_{8} \mathrm{Si}_{6} \mathrm{O}_{20}$ core, with an inversion center (Figure 15). The core structure of 9 contains two symmetry related tetranuclear iron(II) units. Each of these $\mathrm{Fe}_{4} \mathrm{Si}_{3} \mathrm{O}_{10}$ units contains four iron centers, one $\mathrm{SiO}_{3}$ subunit, two $\mathrm{Si}(\mathrm{OH}) \mathrm{O}_{2}$ subunits, and one $\left(\mu_{3}-\mathrm{OH}\right)$ group. Thus, there are three $\mathrm{Fe}_{2} \mathrm{SiO}_{3}[\mathrm{Fe}(2)-\mathrm{O}(31 \mathrm{~A})-\mathrm{Si}(3 \mathrm{~B})-\mathrm{O}(33 \mathrm{~A})-\mathrm{Fe}(3 \mathrm{~A})-\mathrm{O}(24)$; $\mathrm{Fe}(2)-\mathrm{O}(22)-\mathrm{Si}(21)-\mathrm{O}(3 \mathrm{~A})-\mathrm{Fe}(3 \mathrm{~A})-\mathrm{O}(24) ; \quad \mathrm{Fe}(2)-\mathrm{O}(22)-\mathrm{Si}(21)-\mathrm{O}(23)-\mathrm{Fe}(4)-\mathrm{O}(24)] \quad$ sixmembered rings, two $\mathrm{Fe}_{2} \mathrm{Si}_{2} \mathrm{O}_{4}$ [Fe(2)-O(31A)-Si(3B)-O(33A)-Fe(3A)-O(3A)-Si(21)-O(22); $\mathrm{Fe}(2)-\mathrm{O}(22)-\mathrm{Si}(21)-\mathrm{O}(23)-\mathrm{Fe}(4)-\mathrm{O}(4)-\mathrm{Si}(11)-\mathrm{O}(21)]]$ eight-membered rings and one $\mathrm{FeSiO}_{2}$ [Fe(1)-O(13)-Si(11)-O(21)] four-membered ring. Both of the $\mathrm{Fe}_{4} \mathrm{Si}_{3} \mathrm{O}_{10}$ units are fused together to generate two new [Fe(4)-O(32)-Si(31)-O(33)-Fe(3)-O(13)-Si(11)-O(4); Fe(3A)$\mathrm{O}(13 \mathrm{~A})-\mathrm{Si}(1 \mathrm{~B})-\mathrm{O}(4 \mathrm{~A})-\mathrm{Fe}(4 \mathrm{~A})-\mathrm{O}(32 \mathrm{~A})-\mathrm{Si}(3 \mathrm{~B})-\mathrm{O}(33 \mathrm{~A})]$ eight-membered rings which leads to the assembly of the cage structure. An interesting feature of compound 9 is the coordination environment around the iron centers. Thus, there are three iron centers $[\mathrm{Fe}(1), \mathrm{Fe}(3 \mathrm{~A}), \mathrm{Fe}(4)]$ with nearly tetrahedral geometry and one $\mathrm{Fe}(2)$ with a trigonal bipyramidal geometry. Two of these iron atoms $[\mathrm{Fe}(3 \mathrm{~A}), \mathrm{Fe}(4)]$ are surrounded by four oxygen atoms, whereas the remaining two $[\mathrm{Fe}(1), \mathrm{Fe}(2)]$ complete their coordination sphere by accepting an oxygen atom each from the THF molecules. Another interesting aspect of compound 9 is the presence of two different kinds of oxygen environments. Thus, there are six dicoordinate oxygen atoms that bridge Si and $\mathrm{Fe}$ atoms $[\mathrm{O}(22), \mathrm{O}(23), \mathrm{O}(3 \mathrm{~A}), \mathrm{O}(33 \mathrm{~A}), \mathrm{O}(32 \mathrm{~A}), \mathrm{O}(4)]$. The angles at all these oxygen 
atoms are much less that $180^{\circ}$, the largest being at $\mathrm{O}(32)\left(133.9^{\circ}\right)$ and the smallest at $\mathrm{O}(23)$ $\left(118.7^{\circ}\right)$. The remaining four tricoordinate oxygen atoms that cap each one silicon and two iron atoms $[\mathrm{O}(31 \mathrm{~A}), \mathrm{O}(21), \mathrm{O}(13)]$ or cap three iron centers $[\mathrm{O}(24)]$.

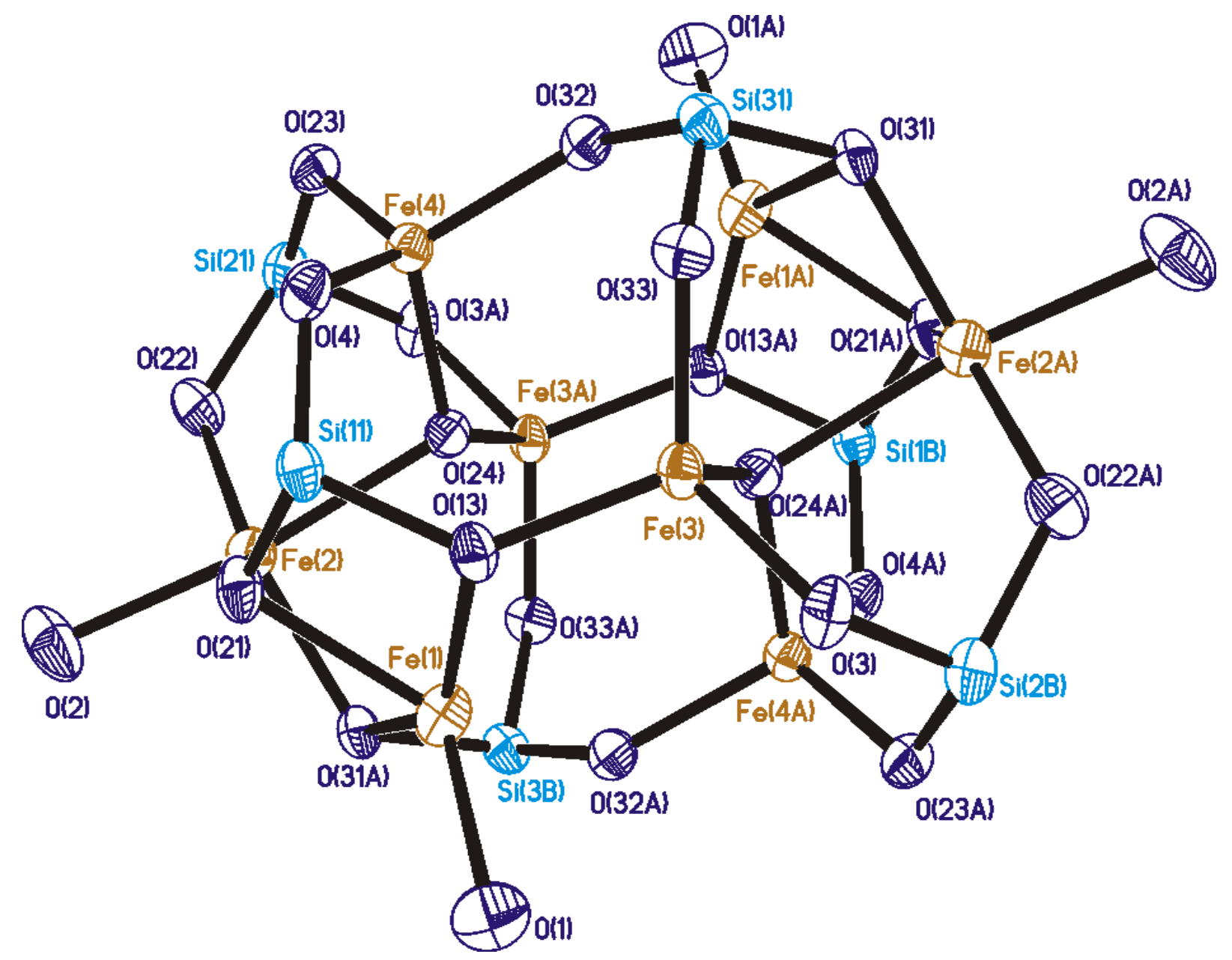

Figure 15. ORTEP diagram of core 9 with $50 \%$ probability. Most of the substituents on silicon and iron atoms are omitted for the sake of clarity. Selected bond lengths $[\AA]$ and angles[ $\left[^{\circ}\right]: \mathrm{Fe}(1)-\mathrm{O}(1) 2.038(4), \mathrm{Fe}(1)-\mathrm{O}(31 \mathrm{~A}) 2.111(4), \mathrm{Fe}(1)-\mathrm{O}(13) 2.116(4), \mathrm{Fe}(1)-\mathrm{O}(21)$ 2.150(4), $\mathrm{Fe}(2)-\mathrm{O}(22)$ 1.954(4), $\mathrm{Fe}(2)-\mathrm{O}(21)$ 1.960(4), Fe(2)-O(31A) 1.971(4), $\mathrm{Fe}(2)-\mathrm{O}(2)$ 2.122(4), $\mathrm{Fe}(2)-\mathrm{O}(24)$ 2.201(4), $\mathrm{Fe}(3)-\mathrm{O}(33)$ 1.845(4), $\mathrm{Fe}(3)-\mathrm{O}(3)$ 1.862(4), $\mathrm{Fe}(3)-\mathrm{O}(24 \mathrm{~A})$ 1.883(4), $\mathrm{Si}(11)-\mathrm{O}(4)$ 1.624(4), $\mathrm{Si}(11)-\mathrm{O}(21)$ 1.637(5), Si(11)-O(13) 1.659(4), Si(21)-O(3A) 1.611(4), $\mathrm{Si}(21)-\mathrm{O}(23)$ 1.614(5), $\mathrm{Si}(21)-\mathrm{O}(22)$ 1.688(4); $\mathrm{O}(1)-\mathrm{Fe}(1)-\mathrm{O}(31 \mathrm{~A})$ 119.54(18), $\mathrm{O}(1)-\mathrm{Fe}(1)-\mathrm{O}(13) \quad 96.04(18), \quad \mathrm{O}(31 \mathrm{~A})-\mathrm{Fe}(1)-\mathrm{O}(13) \quad 142.88(16), \quad \mathrm{O}(1)-\mathrm{Fe}(1)-\mathrm{O}(21)$ 121.54(17), O(31A)-Fe(1)-O(21) 80.38(16), O(13)-Fe(1)-O(21) 71.48(16), O(22)-Fe(2)- 
$\mathrm{O}(21)$ 136.31(19), O(22)-Fe(2)-O(31A) 134.66(19), O(21)-Fe(2)-O(31A) 88.80(17), O(22)$\mathrm{Fe}(2)-\mathrm{O}(24)$ 86.76(17), O(33)- Si (31)-O(32) 113.6(2), Si(31)- O(33)- $\mathrm{Fe}(3)$ 123.9(2), $\mathrm{Si}(21)-\mathrm{O}(23)-\mathrm{Fe}(4)$ 118.7(2), $\mathrm{Si}(11)-\mathrm{O}(4)-\mathrm{Fe}(4)$ 122.7(2), $\mathrm{Si}(21)-\mathrm{O}(22)-\mathrm{Fe}(2)$ 127.5(3), $\mathrm{Si}(21 \mathrm{~A})-\mathrm{O}(3)-\mathrm{Fe}(3) 119.1(2), \mathrm{Si}(31)-\mathrm{O}(32)-\mathrm{Fe}(4) 133.9(2)$.

The Si-O bond distances fall in a narrow range from 1.611(4) $\AA$ to $1.688(4) \AA$ for $\operatorname{Si}(21)-\mathrm{O}(3 \mathrm{~A})$ and $\mathrm{Si}(21)-\mathrm{O}(22)$. The Si-O bond lengths $\mathrm{Si}(11)-\mathrm{O}(13), 1.659(4) \AA$ and $\mathrm{Si}(21)-$ $\mathrm{O}(22) 1.688(4) \AA$ to which a hydrogen atom is attached, are longer than the other two Si-O bond distances around $\mathrm{Si}(11)$ [av 1.631(4) $\AA$ ] and $\mathrm{Si}(21)$ [av 1.613(4) $\AA$ ]. The latter Si-O distances are almost equal to those observed in $\left[\left(\mathrm{RSi}(\mathrm{OH}) \mathrm{O}_{2}\right)_{6} \mathrm{Ti}_{4}\left(\mu_{3}-\mathrm{O}\right)_{2}\right] \cdot 2 \mathrm{THF} .{ }^{[145]} \mathrm{The} \mathrm{Fe}-$ O bond distances range from $1.845(4) \AA$ to $2.201(4) \AA$ for $\mathrm{Fe}(3)-\mathrm{O}(33)$ and $\mathrm{Fe}(2)-\mathrm{O}(24)$, while those involving the $\mu$ oxygens are at the short end of the range 1.845(4) $\AA$ to $1.954(4)$ $\AA$ for $\mathrm{Fe}(3)-\mathrm{O}(33)$ and $\mathrm{Fe}(2)-\mathrm{O}(22)$, and those to the $\mu_{3}$ oxygens are the longest $\mathrm{Fe}(3)-\mathrm{O}(13)$, 1.915(4) $\AA$ and $\mathrm{Fe}(1)-\mathrm{O}(21), 2.150(4) \AA$. The similar range of bond distances is also observed for coordinated THF molecules 2.038(4) $\AA$ to 2.122(5) $\AA$ for $\mathrm{Fe}(1)-\mathrm{O}(1)$ and $\mathrm{Fe}(2)-\mathrm{O}(2)$. As would be expected, the longest Fe-O bond distances are to the capping $\left(\mu_{3}-\mathrm{OH}\right)$ hydroxide (Fe(3)-O(24A), 1.883(4) $\AA ; \mathrm{Fe}(2)-\mathrm{O}(24), 2.201(4) \AA$. To the best of our knowledge such a structural variation within a single molecule is quite remarkable and unique. The metric parameters of compound $\mathbf{9}$ are quite normal and are analogous to those found in earlier examples $\left\{\left[\left(\mathrm{Me}_{3} \mathrm{Si}\right)_{3} \mathrm{SiOFe}\left\{\mu \operatorname{lOSi}\left(\mathrm{SiMe}_{3}\right)_{3}\right\}_{2} \mathrm{Na}(\mathrm{DME})\right] \quad(1.894(2)-1.910(2) \AA \AA) ;{ }^{[135 \mathrm{~b}]}[\{(c-\right.$ $\left.\left.\left.\mathrm{C}_{5} \mathrm{H}_{9}\right)_{7} \mathrm{Si}_{7} \mathrm{O}_{11}\left(\mathrm{OSiMe}_{3}\right)\right\} \mathrm{Fe}(\mathrm{dcpe})\right] \quad(1.866(2)-1.873(3) \quad \AA) ;^{[136 \mathrm{a}]} \quad\left[\left\{\left(\mathrm{Me}_{3} \mathrm{Si}\right)_{3} \mathrm{SiO}\right\}_{2} \mathrm{Fe}\left(2,2^{\prime}-\right.\right.$ dipyridyl) $](1.863(10)-1.899(10) \AA ̊) ;{ }^{[135 \mathrm{~d}]}\left[\left\{\left(\mathrm{Me}_{3} \mathrm{Si}\right)_{2} \mathrm{NFe}\right\}_{2}\{\mathrm{LFe}\}_{2}\left\{\mathrm{O}_{3} \mathrm{SiR}\right\}_{2}\right] \quad(\mathrm{L}=1,3-$ diisopropyl-4,5-dimethylimidazol-2-ylidene) (1.891(2)-2.143(2) $\AA)] .^{[142]}$

Magnetic properties : Magnetic susceptibility measurements for compounds $\mathbf{8}$ and 9 were carried out in two different magnetic fields (2000 G and $5000 \mathrm{G})$, in the temperature range from 295 to $2.0 \mathrm{~K}$. In no case was any significant field dependence of the magnetic data 
observed. Plots of the magnetic moment $\left(\mu_{\mathrm{eff}} / \mu_{\mathrm{B}}\right)$ versus temperature $(T / \mathrm{K})$ for 8 and 9 at $5000 \mathrm{G}$ are depicted in Figure 16. At room temperature the $\mu_{\mathrm{eff}}$ value for $\mathbf{8}$ is $8.92 \mu_{\mathrm{B}}$ that is higher than the value expected for four uncoupled cobalt(II) centers $\left(\mu_{\mathrm{eff}}=7.75 \mu_{\mathrm{B}}\right.$ for $\left.g=2\right)$, whereas for 9 the $\mu_{\text {eff }}$ value is $13.08 \mu_{\mathrm{B}}$, which is slightly lower than the value expected for eight uncoupled iron(II) centers $\left(\mu_{\mathrm{eff}}=13.86 \mu_{\mathrm{B}}\right.$ for $\left.g=2\right)$. Figure 16 shows that $\mu_{\mathrm{eff}}$ decreases when the temperature is lowered. In the case of $\mathbf{8}$ the observed higher magnetic moment is due to the strong spin-orbit coupling typical for high spin Cobalt(II) compounds. The decrease of the magnetic moment with decrease in temperature can also be explained by the effect of spin-orbit coupling or by means of antiferromagnetic exchange interactions within the $\mathrm{Co}_{4}$ core. The reason for having nearly the same observed and expected $\mu_{\text {eff }}$ values in case of compound 9 is due to the weak antiferromagnetic exchange coupling within the $\mathrm{Fe}_{8}$ core. In both 8 and 9 the $\mu_{\text {eff }}$ values tend towards $4.4 \mu_{\mathrm{B}}$ and $5.2 \mu_{\mathrm{B}}$ respectively at low temperature, in accordance with dominant antiferromagnetic exchange interactions.

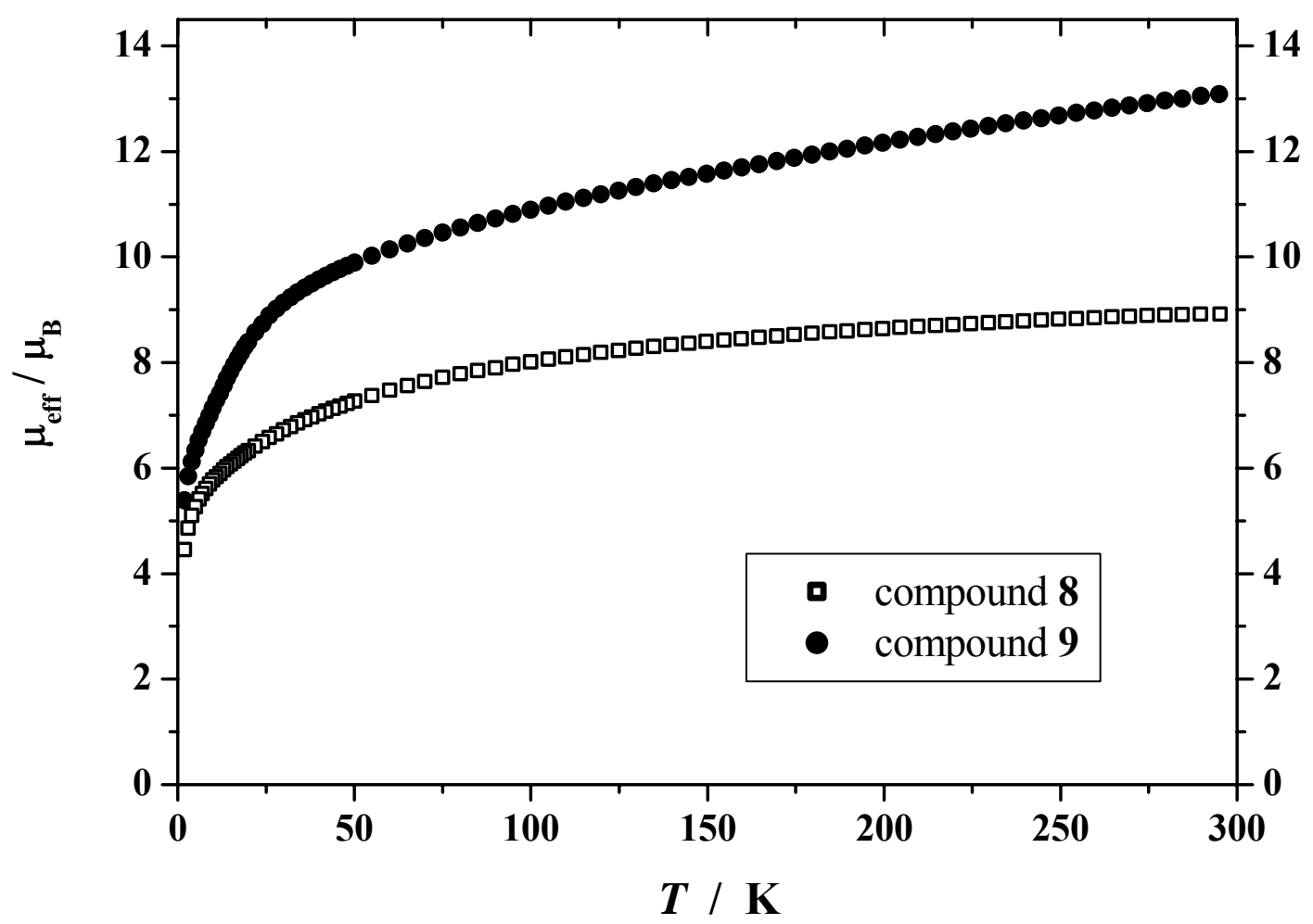

Figure 16. Plot of $\mu_{\text {eff }}\left(\mu_{\mathrm{B}}\right)$ versus $T(\mathrm{~K})$ for compounds 8 and $\mathbf{9}$. 
Thus, we have reported the synthesis and structural characterization of two novel tetrameric cobalt and octameric iron siloxanes, in which the cobalt and iron atoms are in formal oxidation state of + II. Compounds 8 and 9 contain the M/Si ratio of 4:4 and 8:6 respectively. Plots of the magnetic moment $\left(\mu_{\mathrm{eff}} / \mu_{\mathrm{B}}\right)$ versus temperature $(T / \mathrm{K})$ for 8 and 9 revealed antiferromagnetic behaviour for both compounds. 


\section{Summary and Outlook}

\subsection{Summary}

On the basis of the aforementioned results and discussion sections, the priority of the present work was to synthesize soluble metallasiloxanes of Group 8, 9, 14, 15 elements in view to find their application as precursor and catalysts for the metal silicates. The metallasiloxane compounds 2 - 9 have been synthesized in moderate to good yields by the metathesis reactions between lipophilic N-bonded silanetriol, $\mathrm{RSi}(\mathrm{OH})_{3} \quad(\mathrm{R}=(2,6-$ $\left.\left.i \operatorname{Pr}_{2} \mathrm{C}_{6} \mathrm{H}_{3}\right) \mathrm{N}\left(\mathrm{SiMe}_{3}\right)\right)(\mathbf{1})$, and various metal amides with the elimination of respective amines (Schemes 9-11). Compounds 2 - 9 have been unambiguously characterized by means of various physico-chemical techniques such as spectrometric and spectroscopic analysis. The solid state structures of compounds 2 - 9 were determined by single crystal X-ray diffraction analysis. Magnetic susceptibility measurements of the crystalline samples of compounds 7 - 9 were carried out in order to compare their magnetic behaviour.

The reaction of the germanium(II) amide $\mathrm{Ge}\left[\mathrm{N}\left(\mathrm{SiMe}_{3}\right)_{2}\right]_{2}$ with $\mathrm{RSi}(\mathrm{OH})_{3}(\mathbf{1})$ in a $1: 1$ molar ratio leads to the formation of $\left[\mathrm{RSiO}_{3} \mathrm{GeH}\right]_{4}$ (2) that contains Ge-O-Si linkages. The formation of compound $\mathbf{2}$ occurred by an unprecedented oxidative addition reaction involving the $\mathrm{Si}-\mathrm{OH}$ motif to a $\mathrm{Ge}(\mathrm{II})$ center. Thus, the proton of the Si-OH group is formally converted to a hydride. The structure of $\mathbf{2}$ demonstrated that alternating germanium and silicon atoms form the corners of a cube. The twelve Ge ${ }^{\cdots} \cdot \mathrm{Si}$ edges are each bridged by an oxygen atom in a $\mu$ bridging fashion. The presence of $\mathrm{Ge}_{2} \mathrm{O}_{4} \mathrm{Si}_{2}$ eight-membered ring on each face of the cube exists in an approximate cube conformation. 


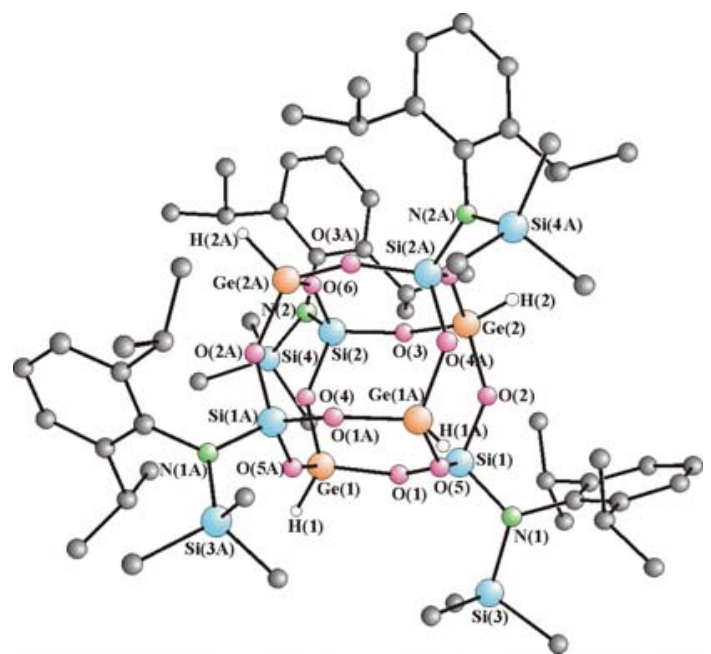

2

From the reaction of $\operatorname{tin}(\mathrm{II})$ amide $\mathrm{Sn}\left[\mathrm{N}\left(\mathrm{SiMe}_{3}\right)_{2}\right]_{2}$ with $\mathrm{RSi}(\mathrm{OH})_{3}$ (1) in a $1.5: 1$ stoichiometric ratio afforded $\left[(\mathrm{SnO})_{6}\left(\mathrm{R}_{2} \mathrm{Si}_{2} \mathrm{O}_{3}\right)_{2}\right](3)$. A notable feature of the reaction is that the silanetriol undergoes a self-condensation to generate the disiloxanetetrol $\left[\left(\mathrm{RSi}(\mathrm{OH})_{2}\right)_{2} \mathrm{O}\right]$ which further reacts with the tin(II) amide. The liberated water from the condensation of the two silanetriol molecules assists in the formation of $\mathrm{SnO}$ from $\mathrm{Sn}\left[\mathrm{N}\left(\mathrm{SiMe}_{3}\right)_{2}\right]_{2}$. Thus, the $(\mathrm{SnO})_{6}$ motif may be considered as a trapped molecular form of tin(II)oxide enveloped by an external siloxane sheath.

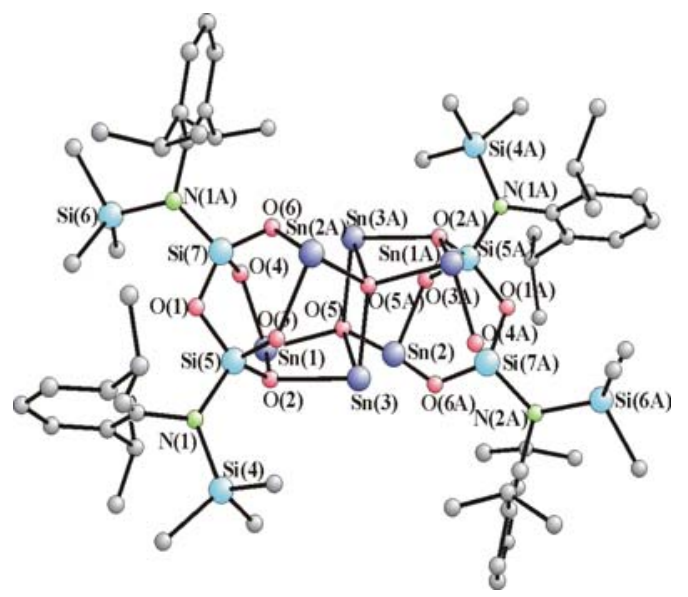

3

The synthesis of $\left[(\mathrm{PbO})_{6}\left(\mathrm{R}_{2} \mathrm{Si}_{2} \mathrm{O}_{3}\right)_{2}\right]$ (4) involves a reaction of lead(II) amide $\mathrm{Pb}\left[\mathrm{N}\left(\mathrm{SiMe}_{3}\right)_{2}\right]_{2}$ and $\mathrm{RSi}(\mathrm{OH})_{3}$ (1) in1.5:1 stoichiometric ratio. Similar to compound 3, compound 4 is also formed as a result of the reaction of the in situ generated disiloxanetetrol $\left[\left(\mathrm{RSi}(\mathrm{OH})_{2}\right)_{2} \mathrm{O}\right]$ with $\mathrm{Pb}\left[\mathrm{N}\left(\mathrm{SiMe}_{3}\right)_{2}\right]_{2}$. The X-ray structure of $\mathbf{4}$ exhibits two 
centrosymmetrically related $\left(\mathrm{Pb}_{3} \mathrm{O}_{6} \mathrm{Si}_{2}\right)$ units that are fused with each other to generate a central diplumboxane motif $\left(\mathrm{Pb}_{2} \mathrm{O}_{2}\right)$, where each $\mathrm{Pb}$ is four-coordinated. In contrast, compound 3 reveals three-coordinated central distannoxane $\left(\mathrm{Sn}_{2} \mathrm{O}_{2}\right)$ unit. Interestingly, these different kind of coordination environments led to the formation of a drum-like cage structure on each half of the central diplumboxane moiety in $\mathbf{4}$ and an incomplete cage on either side of the central distannoxane motif in $\mathbf{3}$.

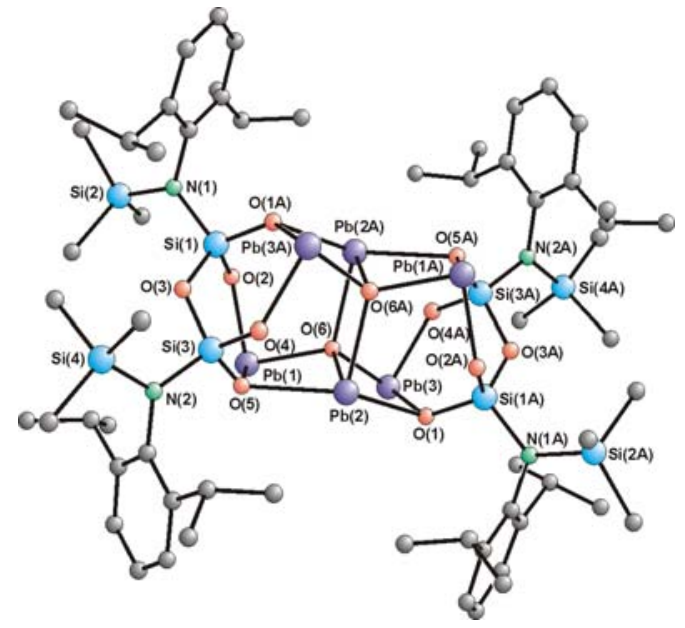

4

The reaction between $\mathrm{Sb}\left(\mathrm{NMe}_{2}\right)_{3}$ and $\mathrm{RSi}(\mathrm{OH})_{3}$ (1) with a 1:1 stoichiometric ratio afforded the antimony(III) siloxane $\left[\mathrm{Sb}\left(\mathrm{O}_{3} \mathrm{SiR}\right)\right]_{4}(\mathbf{5})$. The solid-state structure of 5 indicates a cubic structure having six puckered $\mathrm{Si}_{2} \mathrm{O}_{4} \mathrm{Sb}_{2}$ eight-membered rings. Each of the twelve $\mathrm{Si} \cdots \mathrm{Sb}$ edges is bridged by oxygen atoms in a $\mu$ bridging fashion.

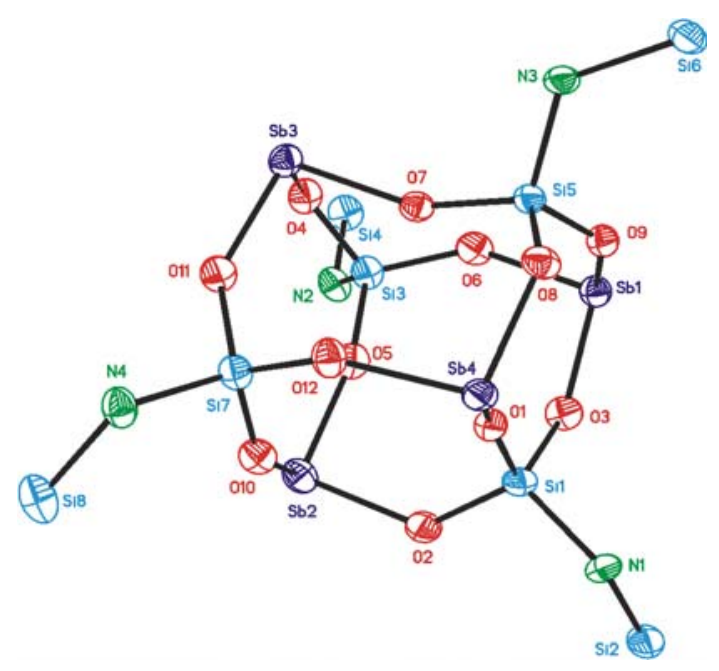


The reaction of bismuth(III) amide and $\mathrm{RSi}(\mathrm{OH})_{3}(\mathbf{1})$ in $1: 1$ molar ratio leads to the formation of $\left[\mathrm{Bi}_{12}\left(\mathrm{O}_{3} \mathrm{SiR}\right)_{8}\left(\mu_{3}-\mathrm{O}\right)_{4} \mathrm{Cl}_{4}(\mathrm{THF})_{8}\right](\mathbf{6})$. The formation of $\mathbf{6}$ is not clear. However we assume that the overall synthesis of $\mathbf{6}$ involves, eight molecules of silanetriol, eight molecules of $\mathrm{Bi}\left(\mathrm{NMe}_{2}\right)_{3}$, four molecules of $\mathrm{Bi}\left(\mathrm{NMe}_{2}\right)_{2} \mathrm{Cl}$, and four molecules of water with the elimination of thirty-two molecules of $\mathrm{HNMe}_{2}$. Several attempts to assemble the analogous bismuth(III) containing chlorine free siloxane cluster were not successful. In our hands only the chlorine containing cluster resulted in the formation of single crystals. The molecular structure of $\mathbf{6}$ consists of a $\mathrm{Bi}_{12} \mathrm{Cl}_{4} \mathrm{O}_{28} \mathrm{Si}_{8}$ core. The core structure of $\mathbf{6}$ contains two $\mathrm{Bi}_{6} \mathrm{Cl}_{2} \mathrm{O}_{14} \mathrm{Si}_{4}$ units that are fused together to generate a $\mathrm{Bi}_{4} \mathrm{Cl}_{2} \mathrm{O}_{4} \mathrm{Si}_{2}$ twelve-membered ring. Each of these $\mathrm{Bi}_{6} \mathrm{Cl}_{2} \mathrm{O}_{14} \mathrm{Si}_{4}$ units is made up of four-(two $\mathrm{Bi}_{2} \mathrm{O}_{2}$ and one $\mathrm{Bi}_{2} \mathrm{ClO}$ ), six-(seven $\mathrm{Bi}_{2} \mathrm{O}_{3} \mathrm{Si}$, one $\mathrm{Bi}_{2} \mathrm{ClO}_{2} \mathrm{Si}$, one $\mathrm{Bi}_{2} \mathrm{ClO}_{2} \mathrm{Si}$ and one $\mathrm{Bi}_{3} \mathrm{O}_{3}$ ) and eight-membered rings (three $\mathrm{Bi}_{2} \mathrm{O}_{4} \mathrm{Si}_{2}$, one $\mathrm{Bi}_{3} \mathrm{O}_{4} \mathrm{Si}$, and one $\mathrm{Bi}_{3} \mathrm{ClO}_{3} \mathrm{Si}$ ).

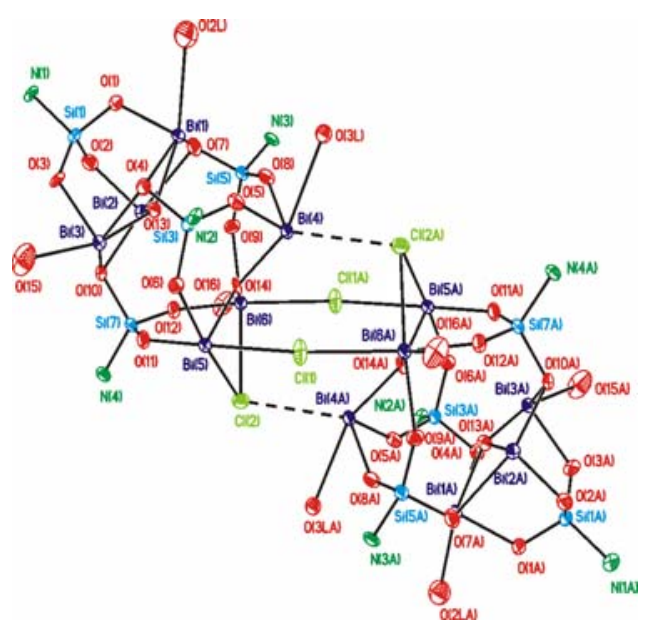

6

The reaction between iron(III) amide and $\mathrm{RSi}(\mathrm{OH})_{3}$ (1) in $1: 1$ molar ratio in the presence of trimethyl phosphine $\mathrm{L}^{1}$ as an auxiliary ligand afforded the ferric siloxane $\left[\left(\mathrm{L}^{1} \mathrm{Fe}\right)\left(\mathrm{O}_{3} \mathrm{SiR}\right)\right]_{4}\left[\mathrm{~L}^{1}=\mathrm{PMe}_{3}\right](7)$. The molecular structure of 7 is made up of a $\mathrm{Fe}_{4} \mathrm{O}_{12} \mathrm{Si}_{4}$ cuboid core where the corners of the cube are alternately occupied by iron and silicon atoms. Each of the twelve edges of the cube contain the bridging oxygen atoms. Thus, the overall 
core structure of the ferric siloxane contains six $\mathrm{Fe}_{2} \mathrm{O}_{4} \mathrm{Si}_{2}$ eight-membered rings as the faces of the cube.

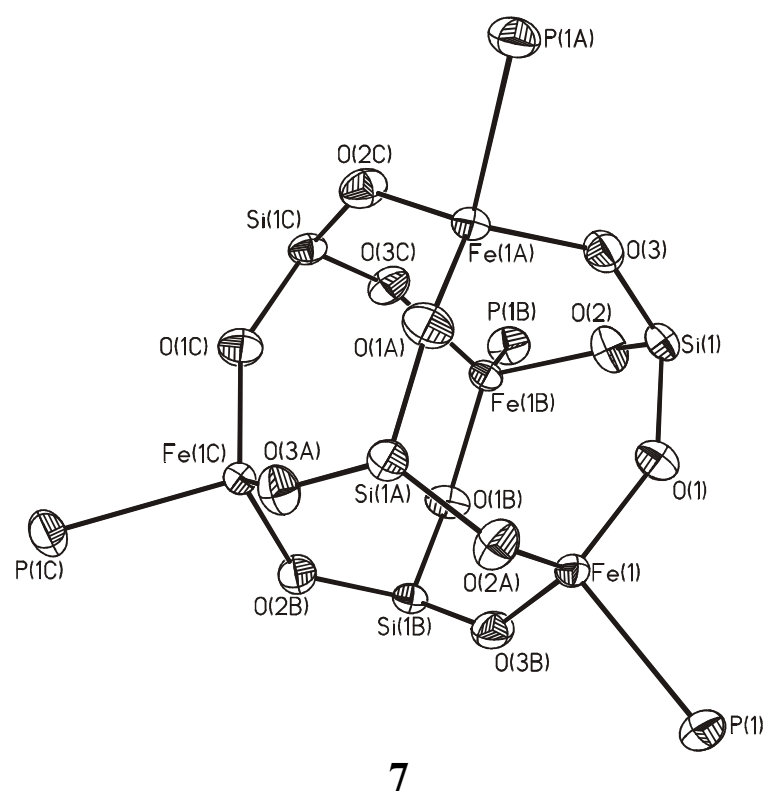

The reaction of cobalt(II) amide with one equivalent of $\mathrm{RSi}(\mathrm{OH})_{3}(\mathbf{1})$ in the presence of trimethylphosphine oxide as an auxiliary ligand leads to the cobalt(II) siloxane $\left[\left(\mathrm{RSi}(\mathrm{OH}) \mathrm{O}_{2}\right) \mathrm{Co}\left(\mathrm{OPMe}_{3}\right)\right]_{4}(\mathbf{8})$. The solid state structure of 8 reveals a dimeric product with two puckered $\mathrm{Co}_{2} \mathrm{O}_{4} \mathrm{Si}_{2}$ boat-like eight-membered rings that are fused together by four $\mathrm{Co}-\mathrm{O}$ bonds. Interestingly, this arrangement leads to the formation of two almost planar fourmembered $\mathrm{Co}_{2} \mathrm{O}_{2}$ rings, and the cobalt atoms of one ring are connected with the oxygens of the second one.

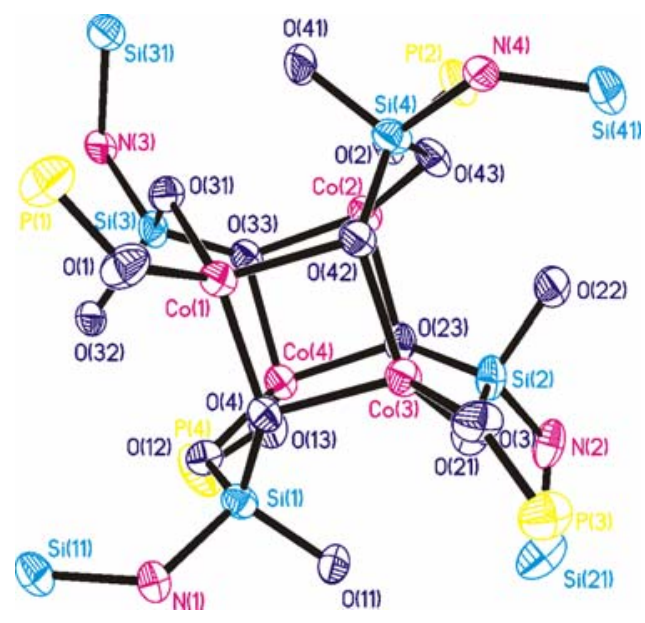

8

The reaction of $\mathrm{Fe}\left[\mathrm{N}\left(\mathrm{SiMe}_{3}\right)_{2}\right]_{2}$ with $\mathrm{RSi}(\mathrm{OH})_{3}$ (1) in a $0.75: 1$ stoichiometric ratio affords the iron(II)siloxane $\left[\left(\mathrm{RSiO}_{3}\right)_{2}\left(\mathrm{RSi}(\mathrm{OH}) \mathrm{O}_{2}\right)_{4}\left(\mu_{3}-\mathrm{OH}\right)_{2} \mathrm{Fe}_{8}(\mathrm{THF})_{4}\right](\mathbf{9})$. The formation of 
compound 9 is still questionable. We assume that the overall reaction takes place among six molecules of silanetriol, eight molecules of $\mathrm{Fe}\left[\mathrm{N}\left(\mathrm{SiMe}_{3}\right)_{2}\right]_{2}$, and two molecules of water that leads to the formation of $\mathbf{9}$. The formation of 9 is insensitive to the slight variations of reactant stoichiometry. Thus, the equimolar quantity of the reactants also leads to the same product formation of $\mathbf{9}$. The core structure of $\mathbf{9}$ contains two symmetric related tetranuclear iron(II) units. The molecular structure of 9 is made up of a $\mathrm{Fe}_{8} \mathrm{Si}_{6} \mathrm{O}_{20}$ core, with an inversion center.

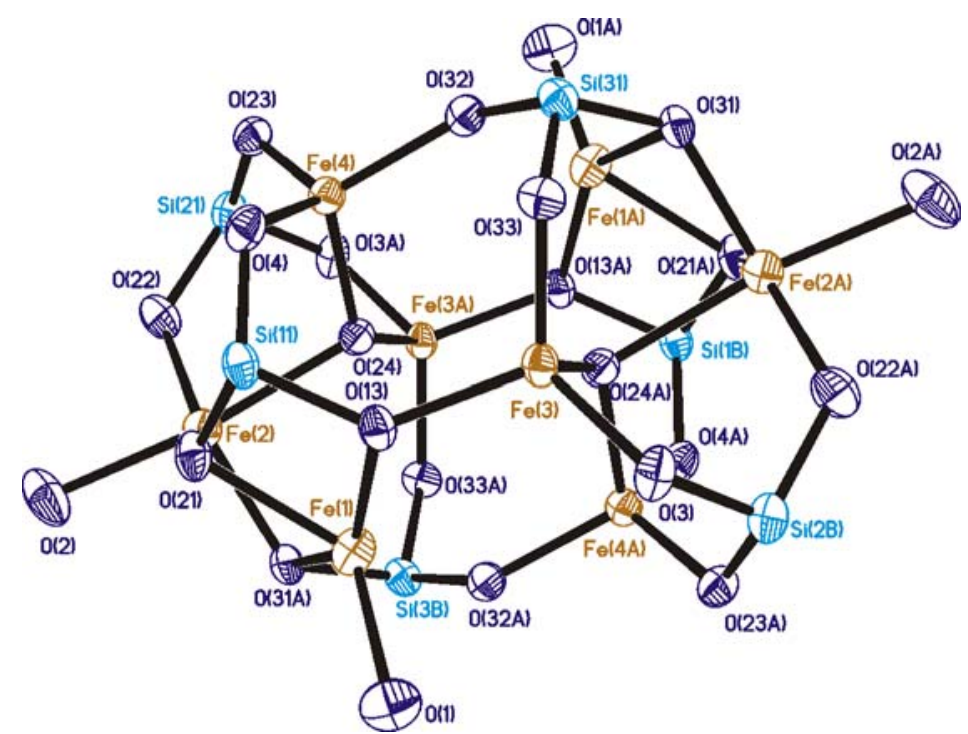

9

Comparison of Spectral and Magnetic Moment of Compounds 2 - 9

All the metallasiloxanes prepared in the present work are thermally stable and do not melt below $240{ }^{\circ} \mathrm{C}$ except 8 and 9 . Under electron impact mass spectral conditions $(70 \mathrm{eV})$ no peak attributable to the molecular ion of $\mathbf{3}$ and 7 - 9 can be observed. Only fragmented peaks were detectable. The IR spectra are devoid of any absorption in the region $3000-3500 \mathrm{~cm}^{-1}$ for compounds $2-7$, indicating complete reaction of all $\mathrm{Si}-\mathrm{OH}$ groups with metal amide, whereas the IR spectrum of $\mathbf{2}$ shows the characteristic Ge-H stretching frequency around $2100 \mathrm{~cm}^{-1}$ whereas, for compounds 8 and 9 exhibit a broad band around $3300 \mathrm{~cm}^{-1}$ for $-\mathrm{OH}$ stretching frequency. Similar to all the other metallasiloxanes, compounds 2 - 9 show very strong absorptions from 900 to $1000 \mathrm{~cm}^{-1}$ assignable to $v(\mathrm{Si}-\mathrm{O}-\mathrm{M})$ vibrations (Table 1$)$. Depending on the type of the $\mathrm{Si}-\mathrm{O}-\mathrm{M}$ bonds, the frequencies of compounds change. It is 
noteworthy that these vibrations are also observed as prominent bands in other transition metal containing siloxanes. The yields of the products varied from moderate to good. (Table 1).

The comparison of ${ }^{29} \mathrm{Si}$ NMR chemical shift data was made from the spectra obtained from the aminosilanetriol (1) and metallasiloxanes $(\mathbf{2}-\mathbf{6})$ that are listed in Table 1. As it can be seen, the ${ }^{29} \mathrm{Si}$ NMR chemical shifts for the $\mathrm{SiO}_{3} \mathrm{~N}$ silicon centers are shifted up-field compared to the values observed in the parent aminosilanetriol (1) $(\delta=-67.3 \mathrm{ppm})$. The largest shift was observed in the case of compound $5(\delta=-91.0 \mathrm{ppm}, \Delta \delta=23.7 \mathrm{ppm})$, whereas the least high-field shift was observed for compound $3(\delta=-70.2 \mathrm{ppm}, \Delta \delta=2.9$ ppm). Plots of magnetic moment $\mu_{\mathrm{eff}}\left(\mu_{\mathrm{B}}\right)$ versus $T(\mathrm{~K})$ for $7-9$ indicates an antiferromagnetic behaviour.

Table 1. Spectral comparison between the metallasiloxanes (2 - 6)

\begin{tabular}{|l|c|c|c|}
\hline \multicolumn{1}{|c|}{$\begin{array}{c}\text { Compound } \\
\left(\mathrm{R}=\left(2,6-i \mathrm{Pr}_{2} \mathrm{C}_{6} \mathrm{H}_{3}\right) \mathrm{N}\left(\mathrm{SiMe}_{3}\right)\right)\end{array}$} & $\begin{array}{c}\text { Yield } \\
(\%)\end{array}$ & $\begin{array}{c}v(\mathrm{Si}-\mathrm{O}-\mathrm{M}) \\
\left(\mathrm{cm}^{-1}\right)^{a}\end{array}$ & $\begin{array}{c}\delta^{29} \mathrm{SiO}_{3} \\
(\mathrm{ppm})^{\mathrm{b}}\end{array}$ \\
\hline$\left[\mathrm{RSiO}_{3} \mathrm{GeH}\right]_{4}(\mathbf{2})$ & 64 & 976,904 & -87.4 \\
\hline$\left[(\mathrm{SnO})_{6}\left(\mathrm{R}_{2} \mathrm{Si}_{2} \mathrm{O}_{3}\right)_{2}\right](\mathbf{3})$ & 65 & $969,955,907$ & -70.2 \\
\hline$\left[(\mathrm{PbO})_{6}\left(\mathrm{R}_{2} \mathrm{Si}_{2} \mathrm{O}_{3}\right)_{2}\right](\mathbf{4})$ & 51 & 936,909 & -74.8 \\
\hline$\left[\mathrm{Sb}\left(\mathrm{O}_{3} \mathrm{SiR}\right)\right]_{4}(\mathbf{5})$ & 83 & $996,959,944,906$ & -91 \\
\hline$\left[\mathrm{Bi}{ }_{12}\left(\mathrm{O}_{3} \mathrm{SiR}_{8}\left(\mu_{3}-\mathrm{O}\right)_{4} \mathrm{Cl}_{4}(\mathrm{THF})_{8}\right](\mathbf{6})\right.$ & 23 & 956,917 & $-72.2,-79.1,-83$ \\
\hline
\end{tabular}

${ }^{\mathrm{a}}$ recorded in Nujol mulls; ${ }^{\mathrm{b}}$ in $\mathrm{C}_{6} \mathrm{D}_{6}$.

Table 2. Magnetic moment comparison between the metallasiloxanes (7 - 9)

\begin{tabular}{|l|c|c|c|}
\hline \multicolumn{1}{|c|}{$\begin{array}{c}\text { Compound } \\
\left(\mathrm{R}=\left(2,6-i \mathrm{Pr}_{2} \mathrm{C}_{6} \mathrm{H}_{3}\right) \mathrm{N}\left(\mathrm{SiMe}_{3}\right)\right)\end{array}$} & $\begin{array}{c}\text { Yield } \\
(\%)\end{array}$ & $\begin{array}{c}v(\mathrm{Si}-\mathrm{O}-\mathrm{M}) \\
\left(\mathrm{cm}^{-1}\right)^{a}\end{array}$ & $\begin{array}{c}\text { Magnetic moment } \\
\mu_{\mathrm{eff}}\left(\mu_{\mathrm{B}}\right)\end{array}$ \\
\hline$\left[\left(\mathrm{L}^{1} \mathrm{Fe}\right)\left(\mathrm{O}_{3} \mathrm{SiR}\right)\right]_{4}(7)$ & 14 & $967,956,923$ & 9.8 \\
\hline$\left[\left(\mathrm{RSi}(\mathrm{OH}) \mathrm{O}_{2}\right) \mathrm{Co}\left(\mathrm{OPMe}_{3}\right)\right]_{4}(\mathbf{8})$ & 43 & 933,910 & 8.9 \\
\hline $\begin{array}{l}{\left[\left(\mathrm{RSiO}_{3}\right)_{2}\left(\mathrm{RSi}(\mathrm{OH}) \mathrm{O}_{2}\right)_{4}\left(\mu_{3^{-}}\right.\right.} \\
\left.\mathrm{OH})_{2} \mathrm{Fe}_{8}(\mathrm{THF})_{4}\right](9)\end{array}$ & 24 & $969,944,905$ & 13.1 \\
\hline
\end{tabular}




\subsection{Outlook}

This thesis deals with the synthesis, spectral studies, structural elucidation, and magnetic properties of metallasiloxanes containing main group and transition metals viz. Ge, $\mathrm{Sn}, \mathrm{Pb}, \mathrm{Sb}, \mathrm{Bi}, \mathrm{Fe}$, and $\mathrm{Co}$. It is noteworthy that these novel metallasiloxanes have been synthesized and structurally characterized for the first time. In view of the scope, an expansion of this work would be to synthesize a new class of metallasiloxanes using rare earth metal amide substrates. The synthesis of metallasiloxanes of lanthanide elements appears to be quite promising for the search of potential precursor and catalysts. Furthermore, the reactivity of metallasiloxane hydride $(\mathrm{Ge}-\mathrm{H})$ derivative $\mathbf{2}$, thus synthesized, may provide an interesting molecule particularly on its reaction with several nucleophilic reagents. Perhaps, investigations on the donor ability of these newly synthesized matallasiloxanes with some metal alkyls like $\mathrm{R}_{3} \mathrm{Al}$ would be an unique approach to find new materials of "high-tech" utility. 


\section{Experimental Section}

\subsection{General Procedures}

All reactions and handling of reagents were performed under an atmosphere of dry nitrogen or argon using Schlenk techniques ${ }^{[148]}$ or a glovebox where the $\mathrm{O}_{2}$ and $\mathrm{H}_{2} \mathrm{O}$ levels were usually kept below $1 \mathrm{ppm}$. All glassware was oven-dried at $140{ }^{\circ} \mathrm{C}$ for at least $24 \mathrm{~h}$, assembled hot and cooled under high vacuum prior to use. Toluene ( $\mathrm{Na} /$ benzophenone ketyl and diphenylether), benzene (K/benzophenone ketyl and diphenylether), hexane $(\mathrm{Na} / \mathrm{K} /$ benzophenone ketyl and diphenylether), pentane $(\mathrm{Na} / \mathrm{K} /$ benzophenone ketyl and diphenylether), tetrahydrofuran (K/benzophenone ketyl), diethylether ( $\mathrm{Na}$ /benzophenone ketyl), dichloromethane $\left(\mathrm{CaH}_{2}\right)$ were dried and distilled prior to use. ${ }^{[149]}$

\subsection{Physical Measurements}

Melting points were measured in sealed glass tubes on a Büchi B-540 melting point apparatus.

NMR spectra were recorded on Bruker Avance 200, Bruker Avance 300, and Bruker Avance 500 NMR spectrometers. Chemical shifts are reported in ppm with reference to $\mathrm{SiMe}_{4}$ (external) for ${ }^{1} \mathrm{H},{ }^{13} \mathrm{C},{ }^{29} \mathrm{Si},{ }^{119} \mathrm{Sn}$ nuclei. Downfield shifts from the reference are quoted positive, upfield shifts are assigned negative values. The NMR grade deuterated solvents were dried in following manners: $\mathrm{C}_{6} \mathrm{D}_{6}$ and toluene - overnight stirring with $\mathrm{Na} / \mathrm{K}$ alloy followed by vacuum distillation, $\mathrm{CDCl}_{3}-3$ min. stirring with $\mathrm{P}_{4} \mathrm{O}_{10}$ followed by filtration, THF storing over freshly activated molecular sieves for one week. Heteroatom NMR spectra were recorded ${ }^{1} \mathrm{H}$ decoupled.

IR spectra were recorded on a Bio-Rad Digilab FTS7 spectrometer. The samples were prepared normally as Nujol mulls between KBr plates.

Mass spectra were obtained with a Finnigan MAT 8230 or a Varian MAT CH5 instrument (70 eV) by EI-MS method. 
Elemental analyses were performed by the Analytisches Labor des Instituts für Anorganische Chemie der Universität Göttingen.

The susceptibility measurements were carried out with a Quantum-Design MPMS-5S SQUID magnetometer in the range from 295 to $2 \mathrm{~K}$. The powdered samples were contained in a gel bucket and fixed in a nonmagnetic sample holder. Each raw data file for the measured magnetic moment was corrected for the diamagnetic contributions of the sample holder and the gel bucket.

Crystal structure determination: Intensity data for compounds $\mathbf{2}, \mathbf{3}, \mathbf{6}, \mathbf{7}, \mathbf{8}$ and 9 were collected on a STOE-IPDS II Stoe image-plate diffractometer. The diffraction data for the compounds $\mathbf{4}$ and $\mathbf{5}$ were measured on a Bruker three-circle diffractometer equipped with a SMART 6000 CCD detector. The data for all the compounds were collected at low temperature (the temperatures for individual compounds are mentioned in the tables in Section 6 using graphite monochromated $\operatorname{MoK}_{\alpha}$ radiation $(\lambda=0.71073 \AA$ ). The data reduction and space group determination were carried out using Siemens SHELXTL program. ${ }^{[150]}$ The structures were solved using either SHELXS-96/97 $7^{[151,152]}$ programs. The refinement of the structures was carried out by full-matrix least-squares method against $F^{2}$ using SHELXL-97. The various advanced features (e.g. restraints and constraints) of SHELXL programs were used to treat the disordered groups, lattice solvents such as THF, and the hydrogen atoms. The non-hydrogen atoms were refined anisotropically A riding model was used for the hydrogen atoms. In compound $\mathbf{5}$, the disordered isopropyl groups and the free THF solvent molecules were refined with distance and ADP restraints. The crystal data for all compounds along with the final residuals and other pertaining details are listed in Section 6 in tabular form. 


\subsection{Starting Materials}

The silanetriol

$\left(2,6-i \mathrm{Pr}_{2} \mathrm{C}_{6} \mathrm{H}_{3}\right) \mathrm{N}\left(\mathrm{SiMe}_{3}\right) \mathrm{Si}(\mathrm{OH})_{3},{ }^{[79]}$

$\mathrm{Ge}\left[\mathrm{N}\left(\mathrm{SiMe}_{3}\right)_{2}\right]_{2},{ }^{[95]}$

$\mathrm{Sn}\left[\mathrm{N}\left(\mathrm{SiMe}_{3}\right)_{2}\right]_{2},{ }^{[95]} \quad \mathrm{Pb}\left[\mathrm{N}\left(\mathrm{SiMe}_{3}\right)_{2}\right]_{2},{ }^{[95]} \quad \mathrm{Sb}\left[\mathrm{N}\left(\mathrm{SiMe}_{3}\right)_{2}\right]_{3},{ }^{[129]} \quad \mathrm{Bi}\left[\mathrm{N}\left(\mathrm{SiMe}_{3}\right)_{2}\right]_{3},{ }^{[130]}$ $\mathrm{Fe}\left[\mathrm{N}\left(\mathrm{SiMe}_{3}\right)_{2}\right]_{2},{ }^{[147]} \mathrm{Fe}\left[\mathrm{N}\left(\mathrm{SiMe}_{3}\right)_{2}\right]_{3},{ }^{[137]} \mathrm{Co}\left[\mathrm{N}\left(\mathrm{SiMe}_{3}\right)_{2}\right]_{2},{ }^{[146]}$ were synthesized using reported procedures. $\mathrm{PMe}_{3}\left(1 \mathrm{M}\right.$ solution in toluene, Fluka), $\mathrm{OPMe}_{3}$ (Acros) were purchased and used as received. $\mathrm{LiN}\left(\mathrm{SiMe}_{3}\right)_{2}$ was prepared prior to use from freshly distilled $\mathrm{HN}\left(\mathrm{SiMe}_{3}\right)_{2}$ and MeLi in pentane. Redistilled $\mathrm{H}_{2} \mathrm{O}$ was degassed prior to use.

\subsection{Syntheses of Compounds 2 - 9}

\subsubsection{Synthesis of $\left[\mathrm{RSiO}_{3} \mathrm{GeH}\right]_{4}\left(\mathrm{R}=\left(2,6-\mathrm{PPr}_{2} \mathrm{C}_{6} \mathrm{H}_{3}\right) \mathrm{N}\left(\mathrm{SiMe}_{3}\right)\right)(2)$}

$\mathrm{Ge}\left[\mathrm{N}\left(\mathrm{SiMe}_{3}\right)_{2}\right]_{2}(1.2 \mathrm{~g}, 3.06 \mathrm{mmol})$ was slowly added to a stirred suspension of the silanetriol $(1.0 \mathrm{~g}, 3.06 \mathrm{mmol})$ in hexane $(20 \mathrm{~mL})$ and THF $(3 \mathrm{~mL})$. During the addition the milky colored suspension of silanetriol changes to a colorless clear solution. The resulting clear solution was stirred for $12 \mathrm{~h}$ at room temperature. The volatile components were removed to obtain a white product. To this hexane $(9 \mathrm{~mL})$ was added. Colorless crystals of 2 were obtained from the concentrated solution after two days at room temperature.

2: Yield: 0.78 g, 64\%. M.p. $251{ }^{\circ} \mathrm{C}$ (decomp.); ${ }^{1} \mathrm{H}$ NMR (300 MHz, $\left.\mathrm{C}_{6} \mathrm{D}_{6}, \mathrm{TMS}\right): \delta=0.19$ (s, 36H, Si $\left.\left(\mathrm{CH}_{3}\right)_{3}\right), 1.22,1.24\left(\mathrm{~d}, 48 \mathrm{H}, \mathrm{CH}\left(\mathrm{CH}_{3}\right)_{2}\right), 3.55$ (sept, 8H, $\left.\mathrm{CH}\left(\mathrm{CH}_{3}\right)_{2}\right), 7.04(\mathrm{~s}, 12 \mathrm{H}$, aromatic), $5.83(\mathrm{~s}, 4 \mathrm{H}, \mathrm{GeH}) ;{ }^{29} \mathrm{Si} \mathrm{NMR}\left(99 \mathrm{MHz}, \mathrm{C}_{6} \mathrm{D}_{6}, \mathrm{TMS}\right): \delta=6.55\left(\mathrm{SiMe}_{3}\right),-87.4$ $\left(\mathrm{SiO}_{3}\right)$; IR (Nujol, KBr): $\widetilde{v}=2211(\mathrm{~m}), 2184(\mathrm{~m}, \mathrm{GeH}), 1439(\mathrm{~m}), 1318(\mathrm{~m}), 1248(\mathrm{~s}), 1183$ (m), 1079 (s), 1045 (s), 1022 (s), 976 (s), 904 (s), 878 (m), 840 (s), 799 (s), 752 (s), 738 (s), $685(\mathrm{w}), 611(\mathrm{~m}), 545(\mathrm{~m}) \mathrm{cm}^{-1}$; EI-MS (70 eV): $m / z(\%): 1592.5$ (100) $\left[M^{+}\right]$; Elemental analysis (\%) calcd. for $\mathrm{C}_{60} \mathrm{H}_{108} \mathrm{Ge}_{4} \mathrm{~N}_{4} \mathrm{O}_{12} \mathrm{Si}_{8}$ (1592.58): C 45.25, H 6.84, N 3.52; found: $\mathrm{C}$ 44.80, H 6.94, N 4.05. 


\subsubsection{Synthesis of $\left[(\mathrm{SnO})_{6}\left(\mathrm{R}_{2} \mathrm{Si}_{2} \mathrm{O}_{3}\right)_{2}\right]\left(\mathrm{R}=\left(2,6-\mathrm{PPr}_{2} \mathrm{C}_{6} \mathrm{H}_{3}\right) \mathrm{N}\left(\mathrm{SiMe}_{3}\right)\right)(3)$}

$\mathrm{Sn}\left[\mathrm{N}\left(\mathrm{SiMe}_{3}\right)_{2}\right]_{2}(2.02 \mathrm{~g}, 4.59 \mathrm{mmol})$ was slowly added to a stirred suspension of the silanetriol $(1.0 \mathrm{~g}, 3.06 \mathrm{mmol})$ in hexane $(25 \mathrm{~mL})$ and THF $(10 \mathrm{~mL})$. After the addition was complete, the reaction mixture was stirred for $1 \mathrm{~h}$ at room temperature. Subsequently, the reaction mixture was refluxed for $1 \mathrm{~h}$. The volatile components were removed to obtain a white solid. To this a mixture of hexane $(10 \mathrm{~mL})$ and THF $(1 \mathrm{~mL})$ was added. Colorless crystals of $\mathbf{3}$ were obtained after four $\mathrm{d}$ at room temperature.

3: Yield: 1.12 g, $65.4 \%$. M.p. $307{ }^{\circ} \mathrm{C}$ (decomp.); ${ }^{1} \mathrm{H}$ NMR (500 MHz, $\left.\mathrm{C}_{6} \mathrm{D}_{6}, \mathrm{TMS}\right): \delta=0.20$ (s, 36H, $\left.\mathrm{Si}\left(\mathrm{CH}_{3}\right)_{3}\right), 1.40,1.42$ (d, 48H, $\left.\mathrm{CH}\left(\mathrm{CH}_{3}\right)_{2}\right), 3.70$ (sept, 8H, $\left.\mathrm{CH}\left(\mathrm{CH}_{3}\right)_{2}\right), 7.05-7.12$ (m, $12 \mathrm{H}$, aromatic); ${ }^{29} \mathrm{Si} \mathrm{NMR}\left(99 \mathrm{MHz}, \mathrm{C}_{6} \mathrm{D}_{6}, \mathrm{TMS}\right): \delta=7.3\left(\mathrm{SiMe}_{3}\right),-70.2\left(\mathrm{SiO}_{3}\right) ;{ }^{119} \mathrm{Sn} \mathrm{NMR}$ (186 MHz, $\left.\mathrm{C}_{6} \mathrm{D}_{6}, \mathrm{TMS}\right): \delta=-138.6,-290.5,-393.1 \mathrm{ppm} ; \mathrm{IR}(\mathrm{Nujol}): \tilde{v}=1316.18(\mathrm{w})$, $1259.28(\mathrm{~s}), 1247.88(\mathrm{~s}), 1179.88$ (m), $1104.7(\mathrm{~m}), 1073.48(\mathrm{w}), 1042.84(\mathrm{~s}), 1007.86(\mathrm{~m})$, 969.36 (s), 954.55 (s), 907.13 (m), 876.99 (m), 836.57 (s), 801.37 (s), $752.60(\mathrm{w}), 721.67$ (w), $685.54(\mathrm{w}), 641.75(\mathrm{w}), 603.08(\mathrm{w}), 543.71(\mathrm{w}), 521.65(\mathrm{~m}), 501.41(\mathrm{w}), 466.34(\mathrm{~m}) \mathrm{cm}^{-1}$; EIMS (70 eV): $m / z(\%): 1740$ (100) $\left[M^{+}-18 \quad \mathrm{CH}_{3}\right]$; Elemental analysis calcd. (\%) for $\mathrm{C}_{60} \mathrm{H}_{104} \mathrm{~N}_{4} \mathrm{O}_{12} \mathrm{Si}_{8} \mathrm{Sn}_{6}$ (2010.43): C 35.85, H 5.21, N 2.79; found: C 36.94, H 5.57, N 2.79.

\subsubsection{Synthesis of $\left[(\mathrm{PbO})_{6}\left(\mathrm{R}_{2} \mathrm{Si}_{2} \mathrm{O}_{3}\right)_{2}\right]\left(\mathrm{R}=\left(2,6-i \mathrm{Pr}_{2} \mathrm{C}_{6} \mathrm{H}_{3}\right) \mathrm{N}\left(\mathrm{SiMe}_{3}\right)\right)(4)$}

$\mathrm{Pb}\left[\mathrm{N}\left(\mathrm{SiMe}_{3}\right)_{2}\right]_{2}(2.42 \mathrm{~g}, 4.59 \mathrm{mmol})$ was slowly added to a stirred suspension of the silanetriol $(1.0 \mathrm{~g}, 3.06 \mathrm{mmol})$ in hexane $(25 \mathrm{~mL})$ and THF $(7 \mathrm{~mL})$. After the addition was complete, the reaction mixture was stirred for $1 \mathrm{~h}$ at room temperature. Subsequently, the reaction mixture was refluxed for $1 \mathrm{~h}$. The volatile components were removed to obtain a white solid. To this a mixture of hexane $(10 \mathrm{~mL})$ and THF $(1 \mathrm{~mL})$ was added. The pale yellow crystals of 4 were obtained by slow cooling its saturated solution after four $\mathrm{d}$ at room temperature. 
4: Yield: 0.99 g, 50.95\%. M.p. $259{ }^{\circ} \mathrm{C}$ (decomp.); ${ }^{1} \mathrm{H}$ NMR (500 MHz, $\left.\mathrm{C}_{6} \mathrm{D}_{6}, \mathrm{TMS}\right): \delta=0.28$ (s, 36H, $\left.\mathrm{Si}\left(\mathrm{CH}_{3}\right)_{3}\right), 1.41,1.43$ (d, 48H, $\left.\mathrm{CH}\left(\mathrm{CH}_{3}\right)_{2}\right), 3.56$ (sept, 8H, $\left.\mathrm{CH}\left(\mathrm{CH}_{3}\right)_{2}\right), 7.6(\mathrm{~m}, 12 \mathrm{H}$, aromatic); ${ }^{29} \mathrm{Si} \mathrm{NMR}\left(99 \mathrm{MHz}, \mathrm{C}_{6} \mathrm{D}_{6}, \mathrm{TMS}\right): \delta=4.41\left(\mathrm{SiMe}_{3}\right),-74.8\left(\mathrm{SiO}_{3}\right)$; IR (Nujol): $\widetilde{v}=$ 1439 (m), 1357 (m), 1322 (m), 1257 (s), 1244 (s), 1185 (m), 1100 (m), 1044 (s), 1019 (m), $936(\mathrm{~s}), 909$ (s), $881(\mathrm{~m}), 835(\mathrm{~s}), 800(\mathrm{~s}), 757(\mathrm{w}), 721(\mathrm{w}), 684(\mathrm{w}), 600(\mathrm{w}), 556(\mathrm{w}), 546$

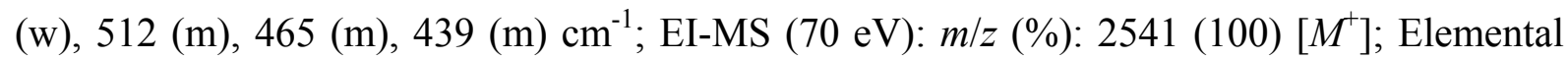
analysis (\%) calcd. for $\mathrm{C}_{60} \mathrm{H}_{104} \mathrm{~N}_{4} \mathrm{O}_{12} \mathrm{~Pb}_{6} \mathrm{Si}_{8}$ (2541.4): C 28.36, H 4.12, N 2.20; found: $\mathrm{C}$ 28.85, H 4.31, N 2.14.

\subsubsection{Synthesis of $\left[\mathrm{Sb}\left(\mathrm{O}_{3} \mathrm{SiR}\right)\right]_{4}\left(\mathrm{R}=\left(2,6-i \mathrm{Pr}_{2} \mathrm{C}_{6} \mathrm{H}_{3}\right) \mathrm{N}\left(\mathrm{SiMe}_{3}\right)\right)(5)$}

To a stirred suspension of silanetriol $(1.4 \mathrm{~g}, 4.28 \mathrm{mmol})$ in hexane $(25 \mathrm{~mL})$ and THF (1 $\mathrm{mL})$, liquid $\mathrm{Sb}\left(\mathrm{NMe}_{2}\right)_{3}(1.09 \mathrm{~g}, 4.28 \mathrm{mmol})$ was added slowly at room temperature to produce a homogeneous solution. During the course of the reaction evolution of dimethylamine was observed. The resulting clear solution was stirred for another $24 \mathrm{~h}$ at room temperature and then heated to reflux for $1 \mathrm{~h}$. The reaction mixture was allowed to cool to room temperature and upon partial removal of the solvent under vacuo a slight turbid solution was obtained, which disappeared after gentle warming. The resulting solution was allowed to crystallize at room temperature to obtain colorless crystals of 5 after $4 \mathrm{~d}$.

5: Yield: 1.59 g, 83\%. M.p: $386-388{ }^{\circ} \mathrm{C}$ (decomp.); ${ }^{1} \mathrm{H}$ NMR (500 MHz, $\left.\mathrm{C}_{6} \mathrm{D}_{6}, \mathrm{TMS}\right): \delta=$ $0.25\left(\mathrm{~s}, 36 \mathrm{H}, \mathrm{Si}\left(\mathrm{CH}_{3}\right)_{3}\right), 1.23,1.26\left(\mathrm{~d}, J=6.9 \mathrm{~Hz}, 48 \mathrm{H}, \mathrm{CH}\left(\mathrm{CH}_{3}\right)_{2}\right), 3.75$ (sept, $J=6.9 \mathrm{~Hz}, 8 \mathrm{H}$, $\left.\mathrm{CH}\left(\mathrm{CH}_{3}\right)_{2}\right), 6.99\left(\mathrm{~m}, 12 \mathrm{H}\right.$, aromatic); ${ }^{29} \mathrm{Si} \mathrm{NMR}\left(99 \mathrm{MHz}, \mathrm{C}_{6} \mathrm{D}_{6}, \mathrm{TMS}\right): \delta=4.4\left(\mathrm{SiMe}_{3}\right)$ and $91\left(\mathrm{SiO}_{3}\right)$; IR (Nujol, KBr): $\widetilde{v}=1364$ (m), 1341 (w), 1318 (m), 1259 (m), 1249 (s), 1182 (s), 1106 (m), 1060 (s), 1043 (s), 996 (m), 959 (s), 944 (s), 906 (s), 892 (s), 838 (s), 801 (s), 754 (m), $722(\mathrm{~m}), 682(\mathrm{w}), 643(\mathrm{w}), 595(\mathrm{w}), 583(\mathrm{~m}), 546(\mathrm{~m}), 484(\mathrm{~m}), 445(\mathrm{w}), 401(\mathrm{~m}) \mathrm{cm}^{-1}$; EI-MS $\quad(70 \mathrm{eV}): \quad m / z \quad(\%): 1784 \quad(100) \quad\left[M^{+}\right] ;$Elemental analysis (\%) calcd. for $\mathrm{C}_{60} \mathrm{H}_{104} \mathrm{~N}_{4} \mathrm{O}_{12} \mathrm{Sb}_{4} \mathrm{Si}_{8}$ (1785.19): C 40.37, H 5.87, N 3.14; found: C 39.56, H 6.26, N 2.64. 


\subsubsection{Synthesis of $\left[\mathrm{Bi}_{12}\left(\mathrm{O}_{3} \mathrm{SiR}\right)_{8}\left(\mu_{3}-\mathrm{O}\right)_{4} \mathrm{Cl}_{4}(\mathrm{THF})_{8}\right]\left(\mathrm{R}=\left(2,6-i \mathrm{Pr}_{2} \mathrm{C}_{6} \mathrm{H}_{3}\right) \mathrm{N}\left(\mathrm{SiMe}_{3}\right)\right)(6)$}

$\mathrm{Bi}\left(\mathrm{NMe}_{2}\right)_{3}(1.46 \mathrm{~g}, 4.28 \mathrm{mmol})$ in hexane $(10 \mathrm{~mL})$ was slowly added to a stirred suspension of the silanetriol $(1.4 \mathrm{~g}, 4.28 \mathrm{mmol})$ in hexane $(10 \mathrm{~mL})$ and $\mathrm{THF}(3 \mathrm{~mL})$ at room temperature. During the course of the reaction evolution of dimethylamine was observed. The resulting clear solution was stirred for another $24 \mathrm{~h}$ at room temperature and then heated to reflux for $1 \mathrm{~h}$. The reaction mixture was allowed to cool to room temperature and upon partial removal of the solvent under vacuo a slight turbid solution was obtained, which disappeared after gentle warming. The resulting solution was allowed to crystallize at room temperature to obtain pale yellow crystals of $\mathbf{6}$ after two weeks.

6: Yield: 0.71 g, 23\%. M.p. $>398{ }^{\circ} \mathrm{C}$ (decomp.); ${ }^{29} \mathrm{Si}$ NMR (99 MHz, $\left.\mathrm{C}_{6} \mathrm{D}_{6}, \mathrm{TMS}\right): \delta=6.4$, 5.5, $2.5\left(\mathrm{SiMe}_{3}\right)$, and -72.2, -79.1, -83 ( $\left.\mathrm{SiO}_{3}\right)$; IR (Nujol): $\widetilde{v}=1320(\mathrm{w}), 1258(\mathrm{~s}), 1245(\mathrm{~s})$, $1184(\mathrm{~m}), 1105$ (m), 1075 (w), 1044 (s), 956 (s), 917 (s), 887 (s), 835 (s), 801 (s), 751 (w), $722(\mathrm{w}), 684(\mathrm{w}), 641(\mathrm{w}), 599(\mathrm{w}), 544(\mathrm{~m}), 501.41(\mathrm{w}), 484(\mathrm{~m}), 419(\mathrm{~m}) \mathrm{cm}^{-1}$; Elemental analysis (\%) calcd. for $\mathrm{C}_{152} \mathrm{H}_{272} \mathrm{Bi}_{12} \mathrm{Cl}_{4} \mathrm{~N}_{8} \mathrm{O}_{36} \mathrm{Si}_{16}$ (5886.76): C 31.01, H 4.66, N 1.90, Cl 2.41; found: C 30.78, H 4.76, N 2.00, C1 1.66.

\subsubsection{Synthesis of $\left[\left(\mathrm{L}^{1} \mathrm{Fe}\right)\left(\mathrm{O}_{3} \mathrm{SiR}\right)\right]_{4}\left(\mathrm{~L}^{1}=\mathrm{PMe}_{3} ; \mathrm{R}=\left(2,6-\mathrm{Pr}_{2} \mathrm{C}_{6} \mathrm{H}_{3}\right) \mathrm{N}\left(\mathrm{SiMe}_{3}\right)\right)(7)$}

$\mathrm{Fe}\left[\mathrm{N}\left(\mathrm{SiMe}_{3}\right)_{2}\right]_{3}(2.3 \mathrm{~g}, 4.28 \mathrm{mmol})$ in hexane $(25 \mathrm{~mL})$ was slowly added to a suspension of silanetriol $(1.4 \mathrm{~g}, 4.28 \mathrm{mmol})$ in the same solvent $(40 \mathrm{~mL})$. After the addition was complete, the reaction mixture was stirred for $72 \mathrm{~h}$ at room temperature. The green colored solution slowly turned to greenish brown. The solvents and hexamethyldisilazane were removed in vacuo to give a brownish-green product. This was recrystallized from a mixture of toluene and THF (1:0.05) in the presence of $\mathrm{PMe}_{3}$ as the auxiliary coordinating ligand at room temperature over a period of two weeks $(0.29 \mathrm{~g}, 14 \%)$ [it was observed that the yield of compound 7 was improved to about $25 \%$ of single crystals by the use of a mixture of hexane and THF (1:0.25) along with $\mathrm{PMe}_{3}$ for crystallization]. 
7: Yield: 0.49 g, 25\%. M.p. $242-244{ }^{\circ} \mathrm{C}$; IR (nujol): $\widetilde{v}=1585,1576,1440,1420,1321,1308$, $1290,1245,1190,1107,1096,1054,1033,967,956,923,836,800,757,749,726,682,642$, 613, 599, 549, 534, 489, 462, $434 \mathrm{~cm}^{-1}$; ESI-MS ( $\left.\mathrm{CH}_{3} \mathrm{CN}\right): m / z(\%) 1750$ (100) $\left[M^{+}-\mathrm{PMe}_{3}\right]$; Elemental analysis calcd. (\%) for (toluene molecules were removed by drying under vacuum) $\mathrm{C}_{72} \mathrm{H}_{140} \mathrm{Fe}_{4} \mathrm{~N}_{4} \mathrm{O}_{12} \mathrm{P}_{4} \mathrm{Si}_{8}$ (1825.89): C 47.36, H 7.73, N 3.07; found: C 46.68, H 7.17, N 3.24.

\subsubsection{Synthesis of $\left[\left(\mathrm{RSi}(\mathrm{OH}) \mathrm{O}_{2}\right) \mathrm{Co}\left(\mathrm{OPMe}_{3}\right)\right]_{4}\left(\mathrm{R}=\left(2,6-i \mathrm{Pr}_{2} \mathrm{C}_{6} \mathrm{H}_{3}\right) \mathrm{N}\left(\mathrm{SiMe}_{3}\right)\right)(8)$}

$\mathrm{Co}\left[\mathrm{N}\left(\mathrm{SiMe}_{3}\right)_{2}\right]_{2}(1.63 \mathrm{~g}, 4.28 \mathrm{mmol})$ in hexane $(10 \mathrm{~mL})$ was slowly added to a suspension of silanetriol $(1.4 \mathrm{~g}, 4.28 \mathrm{mmol})$ in THF/hexane $(2 \mathrm{~mL}, 5 \mathrm{~mL})$. After the addition was completed, the reaction mixture was stirred for $24 \mathrm{~h}$ at room temperature. The green colored solution slowly turned to greenish indigo. A solution of trimethylphosphine oxide $(0.4$ g, $4.34 \mathrm{mmol})$ in THF $(20 \mathrm{~mL})$ was added and the stirring was continued for one more day. The volatile components were removed to obtain a blue solid. To this a mixture of toluene (10 $\mathrm{mL})$ and THF $(1 \mathrm{~mL})$ was added. Blue colored crystals of $\mathbf{8}$ were obtained at room temperature over a period of two weeks.

Addition: We tried $\mathrm{PMe}_{3}$ as well as $\mathrm{OPMe}_{3}$ as coordinating ligand. Only if an impure sample of $\mathrm{PMe}_{3}$ containing some $\mathrm{OPMe}_{3}$ was used for the preparation of $\mathbf{8}$ single crystals of this compound were obtained.

8: Yield: 0.88 g, 43\%. M.p. 196-198 ${ }^{\circ}$ C; IR (nujol): $\widetilde{v}=3381$ (w), 2363 (w), 2254 (w), 2195 (m), $1924(\mathrm{w}), 1863(\mathrm{w}), 1797(\mathrm{w}), 1701(\mathrm{w}), 1653(\mathrm{w}), 1599(\mathrm{~m}), 1579(\mathrm{~m}), 1488(\mathrm{~m}), 1439$ (s), 1407 (s), 1361 (s), 1391 (s), 1249 (s), 1182 (s), 1104 (s), 1027 (s), 933 (s), 910 (s), 880 (s), $838(\mathrm{~s}), 803(\mathrm{~s}), 755(\mathrm{~s}), 685(\mathrm{~m}), 641(\mathrm{w}), 618(\mathrm{w}), 599(\mathrm{~m}), 546(\mathrm{~m}), 489(\mathrm{~m}), 440(\mathrm{~m})$ $\mathrm{cm}^{-1}$; Elemental analysis calcd. (\%) for $\mathrm{C}_{72} \mathrm{H}_{144} \mathrm{Co}_{4} \mathrm{~N}_{4} \mathrm{O}_{16} \mathrm{P}_{4} \mathrm{Si}_{8}$ (1906.24): C 45.37, H 7.61, N 2.94; found: C 44.76, H 7.89, N 3.12. 


\subsubsection{Synthesis of $\left[\left(\mathrm{RSiO}_{3}\right)_{2}\left(\mathrm{RSi}(\mathrm{OH}) \mathrm{O}_{2}\right)_{4}\left(\mu_{3}-\mathrm{OH}\right)_{2} \mathrm{Fe}_{8}(\mathrm{THF})_{4}\right] \quad(\mathrm{R}=(2,6-$ $\left.\left.\operatorname{iPr}_{2} \mathrm{C}_{6} \mathrm{H}_{3}\right) \mathrm{N}\left(\mathrm{SiMe}_{3}\right)\right)(9)$}

The liquid $\mathrm{Fe}\left[\mathrm{N}\left(\mathrm{SiMe}_{3}\right)_{2}\right]_{2} \cdot \mathrm{THF}(2.6 \mathrm{~g}, 5.79 \mathrm{mmol})$ was slowly added to a suspension of $\mathrm{RSi}(\mathrm{OH})_{3}(1.4 \mathrm{~g}, 4.28 \mathrm{mmol})$ in $\mathrm{THF} /$ hexane $(4 \mathrm{~mL}, 25 \mathrm{~mL})$ at room temperature. After stirring for $1 \mathrm{~h}$, the color of the solution turned from green to greenish-blue. The resulting clear solution was stirred for another $48 \mathrm{~h}$ at room temperature and then heated to reflux for 1 h. The solvents and hexamethyldisilazane were removed in vacuo to give a greenish-blue product. This was recrystallized from a mixture of toluene and THF $(8 \mathrm{~mL}, 2 \mathrm{~mL})$. The reddish-yellow crystals of 9 were obtained at $-26{ }^{\circ} \mathrm{C}$ over a period of two weeks 9: Yield: 0.42 g, 24\%. M.p. 210-212 ${ }^{\circ} \mathrm{C}$; IR (nujol): $\widetilde{v}=3652$ (w), 3265 (w), 1320 (w), 1259 (m), 1249 (s), 1184 (m), 1101 (m), 1044 (s), 1018 (m), 969 (s), 944 (s), 905 (s), 840 (s), 802 (s), $755(\mathrm{w}), 722(\mathrm{~m}), 686(\mathrm{w}), 642(\mathrm{w}), 569(\mathrm{~m}), 542(\mathrm{~m}), 478(\mathrm{~m}) \mathrm{cm}^{-1}$; Elemental analysis calcd. (\%)(toluene and THF molecules were removed by drying under vacuum) for $\mathrm{C}_{90} \mathrm{H}_{162} \mathrm{Fe}_{8} \mathrm{~N}_{6} \mathrm{O}_{20} \mathrm{Si}_{12}$ (2432.06): C 44.45, H 6.71, N 3.46; found: C 44.19, H 6.96, N 3.30. 


\section{Handling and Disposal of Solvents and Residual Waste}

1. The recovered solvents were distilled or condensed into cold-traps under vacuum, collected in halogen-free or halogen-containing solvent containers, and stored for disposal.

2. Used NMR solvents were classified into halogen-free or halogen-containing solvents and were disposed as heavy metal-containing wastes and halogen-containing wastes, respectively.

3. The heavy metal residues were dissolved in nitric acid and after neutralization stored in the container for heavy metal wastes.

4. Drying agents such as $\mathrm{KOH}, \mathrm{CaCl}_{2}, \mathrm{MgCl}_{2}, \mathrm{MgSO}_{4}$, and $\mathrm{P}_{4} \mathrm{O}_{10}$ were hydrolyzed and disposed as acid or base wastes.

5. Wherever possible, sodium metal used for drying solvents was collected for recycling. ${ }^{[153]}$ The non-reusable sodium metal was carefully treated with cold ethanol and potassium in cold isopropanol and collected into the base-bath cleaning glassware.

6. Ethanol and acetone used for cooling baths were subsequently used for cleaning glassware.

7. The acid bath for cleaning glassware was neutralized with $\mathrm{Na}_{2} \mathrm{CO}_{3}$ and the resulting $\mathrm{NaCl}$ solution was washed off in the water drainage system.

8. The residual of the base both for cleaning glassware was poured into the container for base wastes. 
Amount of various types of disposable wastes generated during the work.

Metal containing wastes

Halogen-containing wastes

Halogen-free solvent wastes

Acid wastes

Base wastes
$5 \mathrm{~L}$

$4 \mathrm{~L}$

$40 \mathrm{~L}$

$12 \mathrm{~L}$

$12 \mathrm{~L}$ 


\section{Crystal Data and Refinement Details}

Table CD1. Crystal data and structure refinement for 2.

\begin{tabular}{|c|c|}
\hline Identification code & aum217 \\
\hline Empirical formula & $\mathrm{C}_{60} \mathrm{H}_{108} \mathrm{Ge}_{4} \mathrm{~N}_{4} \mathrm{O}_{12} \mathrm{Si}_{8}$ \\
\hline Formula weight & 1592.58 \\
\hline Temperature & $133(2) \mathrm{K}$ \\
\hline Wavelength & $0.71073 \AA$ \\
\hline Crystal system & monoclinic \\
\hline Space group & $C 2 / c$ \\
\hline \multirow[t]{3}{*}{ Unit cell dimensions } & $a=26.4229(12) \AA, \alpha=\gamma=90^{\circ}$. \\
\hline & $b=12.5692(6) \AA, \beta=112.945(4)^{\mathrm{o}}$. \\
\hline & $c=26.1702(12) \AA$. \\
\hline Volume & $8003.8(6) \AA^{3}$ \\
\hline$Z$ & 4 \\
\hline Calculated density & $1.322 \mathrm{Mg} / \mathrm{m}^{3}$ \\
\hline Absorption coefficient & $1.660 \mathrm{~mm}^{-1}$ \\
\hline$F(000)$ & 3328 \\
\hline$\theta$ range for data collection & 1.67 to $24.83 \mathrm{deg}$. \\
\hline Index ranges & $-31 \leq h \leq 31,-14 \leq k \leq 14,-30 \leq l \leq 30$ \\
\hline Reflections collected & 41571 \\
\hline$R$ (int) & 0.0622 \\
\hline Refinement method & Full-matrix least-squares on $F^{2}$ \\
\hline Data / restraints / parameters & $6890 / 0 / 419$ \\
\hline Goodness-of-fit on $F^{2}$ & 1.013 \\
\hline Final $R$ indices $[I>2 \sigma(I)]$ & $R 1=0.0252, w R 2=0.0595$ \\
\hline$R$ indices (all data) & $R 1=0.0322, w R 2=0.0622$ \\
\hline Largest difference peak and hole & 0.296 and $-0.380 \mathrm{e} \cdot \AA^{3}$ \\
\hline
\end{tabular}


Table CD2. Crystal Data and Structure Refinement Details for $3 \cdot 2 \mathrm{C}_{4} \mathrm{H}_{8} \mathrm{O} \cdot \mathrm{C}_{6} \mathrm{H}_{14}$.

Identification code

Empirical formula

Formula weight

Temperature

Wavelength

Crystal system

Space group

Unit cell dimensions

Volume

$Z$

Calculated density

Absorption coefficient

$F(000)$

$\theta$ range of collection

Index range

Reflections collected

$R$ (int)

Refinement method

Data/ restraints/ parameters

Goodness-of-fit on $F^{2}$

Final $R$ indices $[I>2 \sigma(I)]$

$R$ indices (all data)

Largest difference peak and hole aum47

$\mathrm{C}_{74} \mathrm{H}_{134} \mathrm{~N}_{4} \mathrm{O}_{14} \mathrm{Si}_{8} \mathrm{Sn}_{6}$

2240.71

133(2) K

$0.71073 \AA$

monoclinic

$P 2_{1} / c$

$a=14.5130(7) \AA, \alpha=\gamma=90^{\circ}$.

$b=17.3237(9) \AA, \beta=105.986(4)^{\circ}$.

$c=19.8882(4) \AA$.

4806.9(4) $\AA^{3}$

2

$1.548 \mathrm{Mg} / \mathrm{m}^{3}$

$1.690 \mathrm{~mm}^{-1}$

2260

1.59 to $24.81 \mathrm{deg}$

$-17 \leq h \leq 17,-20 \leq k \leq 20,-23 \leq l \leq 23$

47029

0.0316

Full-matrix least-squares on $F^{2}$

$8260 / 0 / 502$

1.022

$R 1=0.0195, w R 2=0.0484$

$R 1=0.0238, w R 2=0.0498$

0.583 and -0.411 e $\AA^{-3}$ 
Table CD3. Crystal data and structure refinement for $4 \cdot 4 \mathrm{C}_{4} \mathrm{H}_{8} \mathrm{O}$.

Identification code

Empirical formula

Formula weight

Temperature

Wavelength

Crystal system

Space group

Unit cell dimensions

Volume

Z

Calculated density

Absorption coefficient

$F(000)$

$\theta$ range for data collection

Index ranges

Reflections collected

R(int)

Refinement method

Data / restraints / parameters

Goodness-of-fit on $F^{2}$

Final R indices $[I>2 \sigma(I)]$

$R$ indices (all data)

Largest difference peak and hole test

$\mathrm{C}_{76} \mathrm{H}_{136} \mathrm{~N}_{4} \mathrm{O}_{16} \mathrm{~Pb}_{6} \mathrm{Si}_{8}$

2829.75

100(2) K

$1.54178 \AA$

monoclinic

$P 21_{1} / n$

$a=18.664(1) \AA, \alpha=\gamma=90^{\circ}$.

$b=12.693(1) \AA, \beta=97.19(1)^{\circ}$.

$c=20.651(1) \AA$,

4854(1) $\AA^{3}$

2

$1.936 \mathrm{Mg} / \mathrm{m}^{3}$

$21.222 \mathrm{~mm}^{-1}$

2704

1.50 to $29.43 \mathrm{deg}$.

$-20<=h<=20,-14<=k<=13,-22<=l<=22$

21054

0.0300

Full-matrix least-squares on $F^{2}$

$6771 / 172 / 547$

1.027

$R 1=0.0205, w R 2=0.0472$

$R 1=0.0244, w R 2=0.0485$

0.723 and $-0.774 \mathrm{e} \cdot \mathrm{A}^{-3}$ 
Table CD4. Crystal data and structure refinement for $5 \cdot 1.34 \mathrm{C}_{4} \mathrm{H}_{8} \mathrm{O}$.

Identification code

Empirical formula

Formula weight

Temperature

Wavelength

Crystal system

Space group

Unit cell dimensions

Volume

Z

Calculated density

Absorption coefficient

$F(000)$

$\theta$ range for data collection

Index ranges

Reflections collected

$R$ (int)

Refinement method

Data / restraints / parameters

Goodness-of-fit on $F^{2}$

Final $R$ indices $[I>2 \sigma(I)]$

$R$ indices (all data)

Largest diffifference peak and hole 0.742 and $-0.624 \mathrm{e} \cdot \AA^{-3}$ aum351

$\mathrm{C}_{65.37} \mathrm{H}_{114.73} \mathrm{~N}_{4} \mathrm{O}_{13.34} \mathrm{Sb}_{4} \mathrm{Si}_{8}$

1881.92

$100(2) \mathrm{K}$

$1.54178 \AA$

monoclinic

$P 2_{1} / n$

$a=27.075(6) \AA, \alpha=\gamma=90^{\circ}$.

$b=14.923(4) \AA, \beta=94.93(3)^{\circ}$

$c=41.644(10) \AA$,

16764(7) $\AA^{3}$

8

$1.491 \mathrm{Mg} / \mathrm{m}^{3}$

$11.666 \mathrm{~mm}^{-1}$

7661

1.01 to $29.51^{\circ}$

$-26 \leq h \leq 30,-16 \leq k \leq 16,-41 \leq l \leq 43$

23725

0.0797

Full-matrix least-squares on $F^{2}$

23725 / 2690 / 2075

1.003

$R 1=0.0367, w R 2=0.0681$

$R 1=0.0627, w R 2=0.0764$ 
Table CD5. Crystal data and structure refinement for $6 \cdot 2 \mathrm{C}_{4} \mathrm{H}_{8} \mathrm{O}$.

Identification code

Empirical formula

Formula weight

Temperature

Wavelength

Crystal system

Space group

Unit cell dimensions

Volume

$Z$

Calculated density

Absorption coefficient

$F(000)$

$\theta$ range for data collection

Index ranges

Reflections collected

$R$ (int)

Refinement method

Data / restraints / parameters

Goodness-of-fit on $F^{2}$

Final $R$ indices $[I>2 \sigma(I)]$

$\mathrm{R}$ indices (all data)

Largest difference peak and hole aum317

$\mathrm{C}_{160} \mathrm{H}_{288} \mathrm{Bi}_{12} \mathrm{Cl}_{4} \mathrm{~N}_{8} \mathrm{O}_{38} \mathrm{Si}_{16}$

6030.98

133(2) K

$0.71073 \AA$

monoclinic

$P 2{ }_{1} / n$

$a=22.9236(7) \AA, \alpha=\gamma=90^{\circ}$.

$b=19.0353(5) \AA, \beta=94.025(3)^{\mathrm{o}}$.

$c=23.7193(8) \AA$

$10324.6(5) \AA^{3}$

2

$1.940 \mathrm{Mg} / \mathrm{m}^{3}$

$10.396 \mathrm{~mm}^{-1}$

5792

1.28 to $24.36 \mathrm{deg}$.

$-26 \leq h \leq 26,-22 \leq k \leq 21,-27 \leq l \leq 27$

54953

0.0672

Full-matrix least-squares on $F^{2}$

16691 / 0 / 1025

1.021

$R 1=0.0329, w R 2=0.0681$

$R 1=0.0483, w R 2=0.0772$

1.589 and $-1.196 \mathrm{e} \cdot \mathrm{A}^{-3}$ 
Table CD6. Crystal data and structure refinement for $7 \cdot 2 \mathrm{C}_{7} \mathrm{H}_{8}$.

Identification code

Empirical formula

Formula weight

Temperature

Wavelength

Crystal system

Space group

Unit cell dimensions

Volume

Z

Calculated density

Absorption coefficient

$F(000)$

$\theta$ range for data collection

Index ranges

Reflections collected

$R$ (int)

Refinement method

Data / restraints / parameters

Goodness-of-fit on $F^{2}$

Final $R$ indices $[I>2 \sigma(I)]$

$R$ indices (all data)

Largest difference peak and hole aum72

$\mathrm{C}_{86} \mathrm{H}_{156} \mathrm{Fe}_{4} \mathrm{~N}_{4} \mathrm{O}_{12} \mathrm{P}_{4} \mathrm{Si}_{8}$

2010.15

133(2) K

$0.71073 \AA$

tetragonal

$P \overline{4} 2{ }_{1} / c$

$a=b=19.7056(11) \AA, \alpha=\beta=\gamma=90^{\circ}$

$c=15.1916(11) \AA$

5899.1(6) $\AA^{3}$

2

$1.132 \mathrm{Mg} / \mathrm{m}^{3}$

$0.666 \mathrm{~mm}^{-1}$

2144

1.69 to $24.81 \mathrm{deg}$.

$-23 \leq h \leq 20,-23 \leq k \leq 19,-17 \leq l \leq 11$.

12247

0.0352

Full-matrix least-squares on $F^{2}$

4732 / 0 / 277

1.085

$R 1=0.0431, w R 2=0.1272$

$R 1=0.0491, w R 2=0.1309$

0.752 and $-0.249 \mathrm{e} \cdot \mathrm{A}^{-3}$ 
Table CD7. Crystal data and structure refinement for 8.

Identification code

Empirical formula

Formula weight

Temperature

Wavelength

Crystal system

Space group

Unit cell dimensions

Volume

Z

Calculated density

Absorption coefficient

$F(000)$

$\theta$ range for data collection

Index ranges

Reflections collected

$R$ (int)

Refinement method

Data / restraints / parameters

Goodness-of-fit on $F^{2}$

Final $R$ indices $[I>2 \sigma(I)]$

$R$ indices (all data)

Largest difference peak and hole r1173

$\mathrm{C}_{72} \mathrm{H}_{144} \mathrm{Co}_{4} \mathrm{~N}_{4} \mathrm{O}_{16} \mathrm{P}_{4} \mathrm{Si}_{8}$

1906.23

133(2) K

$0.71073 \AA$

monoclinic

$P 2_{1} / c$

$a=28.705(6) \AA, \alpha=\gamma=90^{\circ}$.

$b=27.685(6) \AA, \beta=106.41(3)^{\circ}$.

$c=29.579(6) \AA$

2255(1) $\AA^{3}$

8

$1.123 \mathrm{Mg} / \mathrm{m}^{3}$

$0.769 \mathrm{~mm}^{-1}$

8096

1.60 to $24.92^{\circ}$.

$-32 \leq h \leq 33,-31 \leq k \leq 32,-34 \leq l \leq 34$

60890

0.1441

Full-matrix least-squares on $F^{2}$

$30611 / 2771 / 2032$

0.697

$R 1=0.0676, w R 2=0.1319$

$R 1=0.2562, w R 2=0.1844$

0.777 and $-0.382 \mathrm{e} \cdot \AA^{-}-3$ 
Table CD8. Crystal data and structure refinement for $9 \cdot 4 \mathrm{C}_{4} \mathrm{H}_{8} \mathrm{O} \cdot 6 \mathrm{C}_{6} \mathrm{H}_{14}$

Identification code

Empirical formula

Formula weight

Temperature

Wavelength

Crystal system

Space group

Unit cell dimensions

Volume

$Z$

Calculated density

Absorption coefficient

$F(000)$

$\theta$ range for data collection

Index ranges

Reflections collected

$R$ (int)

Refinement method

Data / restraints / parameters

Goodness-of-fit on $F^{2}$

Final $R$ indices $[I>2 \sigma(I)]$

$R$ indices (all data)

Largest difference peak and hole r1186

$\mathrm{C}_{148} \mathrm{H}_{242} \mathrm{Fe}_{8} \mathrm{~N}_{6} \mathrm{O}_{24} \mathrm{Si}_{12}$

3273.32

133(2) K

$0.71073 \AA$

triclinic

$P_{1}^{-}$

$a=16.129(13) \AA, \alpha=61.55(4)^{\circ}$.

$b=16.787(13) \AA, \beta=81.35(5)^{\circ}$.

$c=17.464(14) \AA, \gamma=86.55(5)^{\circ}$.

4109.9(6) $\AA^{3}$

1

$1.320 \mathrm{Mg} / \mathrm{m}^{3}$

$0.837 \mathrm{~mm}^{-1}$

1734

1.87 to $24.79^{\circ}$.

$-18 \leq h \leq 17,-19 \leq k \leq 19,-20 \leq l \leq 20$

76145

0.1561

Full-matrix least-squares on $F^{2}$

$13591 / 0 / 916$

0.927

$R 1=0.0693, w R 2=0.1230$

$R 1=0.1466, w R 2=0.1433$

0.682 and $-0.491 \mathrm{e} \cdot \AA^{-3}$ 


\section{References}

[1] N. N. Greenwood, A. Earnshaw, Chemistry of the Elements, $1^{\text {st }}$ ed., Pergamon Press, Oxford, 1984.

[2] F. A. Cotton, G. Wilkinson, C. A. Murillo, M. Bochmann, Advanced Inorganic Chemistry; $6^{\text {th }}$ ed., John Wiley and Sons, New York, 1999.

[3] A. F. Wells, Structural Inorganic Chemistry, $5^{\text {th }}$ ed., Clarendon Press, Oxford, 1984.

[4] J. W. McBain, in A Survey of the Main Principles of Colloid Science, colloid Symp. Mongr. 1926, 4, 7-18.

[5] A. F. Cronstedt, Kongl. Svenska Vetensk. Acad. Handl. 1756, 17, 120.

[6] F. Grandjean, Compt. Reud. Hedb. Seanc. Acad. Sci. Paris, 1909, 149, 866.

[7] O. Weigel, E. Steinhoff, Z. Kristallogr. 1925, 61, 125-154.

[8] R. M. Milton, in Molecular Sieves, Soc. of Chem. Ind., London, 1968.

[9] Zeolite Microporous Solids: Synthesis, Structure and Reactivity, E. G. Derouane, F. Lemos, C. Naccache, F. R. Ribeiro, (Eds.), Kluwer Academic Press, Dordrecht, 1992.

[10] Catalytic Science and Technology, Vol. 1, S. Yoshida, N. Takezawa, T. Ono, (Eds.), Kodansha, Tokyo and VCH, Weinheim, 1991.

[11] H. Kessler, in Stud. Surf. Sci. Catal.: Recent Advances in Zeolite Science, J. Klinowski, P. J. Barrie, (Eds.), Elsevier, Amsterdam, 1989, 52, 17-37.

[12] W. Johnson, A. J. Jacobson, W. M. Butler, S. E. Rosenthal, J. F. Brody, J. T. Lewandowski, J. Am. Chem. Soc. 1989, 111, 381-383.

[13] S. L. Meisel, J. P. McCullogh, C. H. Lechtaler, P. B. Weisz, Chem. Tech. 1976, 6, 8689.

[14] L. Smart, E. Moore, Solid State Chemistry, Chapman and Hall, London, 1992, p181.

[15] F. Schüth, Chem. uns. Zeit 1995, 29, 42-52.

[16] A. Dyer, An Introduction to Zeolite Molecular Sieves, John Wiley: New York, 1988. 
[17] C. Baerlocher, W. M. Meier, D. H. Olson, Atlas of Zeolite Structure Types, $5^{\text {th }}$ ed., Elsevier, London, 2001.

[18] D. Freude, H. Ernst, T. Mildner, H. Pfeifer, I. Wolf, in Stud, Surf. Sci. Catal.: Acid Base Catalysis II, H. Hattori, M. Misono, Y. Ono, (Eds.), Elsevier, Amsterdam and Kodansha, Tokyo, 1989, 90, 105-116.

[19] R. M. Barrer, Zeolites and Clay Minerals as Sorbents and Molecular Sieves, Academic Press, London, 1978.

[20] R. J. Argauer, G. R. Landolt, U. S. Patent, 3,702,886, 1972.

[21] R. Szostak, Molecular Sieves: Principal of Synthesis and Identification, New York: Van Nostrand, Reinholg Catalysis Series 1989.

[22] E. M. Flanigen, J. M. Bennett, R. W. Grose, J. P. Cohen, R. L. Patton, R. L. Kirchner, J. V. Smith, Nature, 1978, 271, 512-516.

[23] R. W. Grose, E. M. Flanigen, U. S. Patent, 4,061,724, 1977; Chem. Abs. 88: 142183.

[24] C. S. Cundy, P. A. Cox, For a Survey of Preparation of Zeolites through Hydrothermal Synthesis: Chem. Rev. 2003, 103, 663-701.

[25] P. Behrens, G. D. Stucky, Angew. Chem. 1993, 105, 729-732; Angew. Chem. Int. Ed. Engl. 1993, 32, 696-699.

[26] C. T. Kresge, M. E. Leonowicz, W. J. Roth, J. C. Vartuli, J. S. Beck, Nature 1992, $359,710-712$.

[27] R. J. Francis, D. O’Hare, J. Chem. Soc., Dalton Trans. 1998, 3133-3148.

[28] C. S. Cundy, P. A. Cox, Chem. Soc. Rev. 2003, 103, 663-701.

[29] L. A. M. M. Barbosa, R. A. van Santen, J. Hafner, J. Am. Chem. Soc. 2001, 123, 4530-4540.

[30] M. F. Ciraolo, P. Norby, J. C. Hanson, D. R. Corbin, C. P. Grey, J. Phys. Chem. B 1999, 103, 346-356. 
[31] D. R. Uhlmann, D. R. Ulrich, Ultrastructure Processing of Advanced Materials, (Eds.), Wiley-Interscience, New York, 1992.

[32] M. J. Hampden-Smith, W. G. Klemperer, C. J. Brinker, Better Ceramics Through Chemistry V, Materials Research Proceedings, Vol. 271, (Eds.), Mat. Res. Soc., Pittsburgh, 1992.

[33] D. W. Bruce, D. O’Hare, Inorganic Materials, (Eds.), Wiley, New York, 1992.

[34] A. Stein, S. W. Keller, T. E. Mallouk, Science, 1993, 259, 1558-1564.

[35] D. B. Amabilino, J. F. Stoddart, Chem. Rev. 1995, 95, 2725-2828.

[36] C. L. Bowes, G. A. Ozin, Adv. Mater. 1996, 8, 13-28.

[37] C. J. Brinker, G. W. Scherer, Sol-Gel Science; Academic Press, Boston, 1990.

[38] L. G. Hubert-Pfalzgraf, Coord. Chem. Rev. 1998, 178, 967-997.

[39] R. C. Mehrotra, J. Non-Cryst. Solids, 1988, 100, 1-15.

[40] C. Sanchez, J. Livage, M. Henry, F. J. Babonneau, J. Non-Cryst. Solids, 1988, 100, $65-76$.

[41] C. D. Chandler, C. Roger, M. J. Hampden-Smith, Chem. Rev. 1993, 93, 1205-1241.

[42] L. C. Klein, Sol-Gel Technology for Thin Films, Fibers, Preforms, Electronics, and Specialty Shape, Noyes, Park Ridge, 1988.

[43] A. H. Cowley, R. A. Jones, Angew. Chem. 1989, 101, 1235-1243; Angew. Chem. Int. Ed. Engl. 1989, 28, 1208-1215.

[44] A. G. Williams, L. V. Interrante, In Better Ceramics Through Chemistry; Materials Research Society, Symposia Proceedings, Vol. 32, C. J. Brinker, D. E Clark, D. R. Ulrich, (Eds.), North Holland, New York, 1984, p 152.

[45] A. W. Apblett, A. C. Warren, A. R. Barron, Chem. Mater. 1992, 4, 167-182.

[46] D. M. Hoffman, Polyhedron, 1994, 13, 1169-1179.

[47] F. Chaput, A. Lecomte, A. Dauger, J. P. Boilot, Chem. Mater. 1989, 1, 199-201.

[48] P. D. Lickiss, Adv. Inorg. Chem. 1995, 42, 147-262. 
[49] V. Chandrasekhar, R. Boomishankar, S. Nagendran, Chem. Rev. 2004, 104, 58035821.

[50] V. Chandrasekhar, S. Nagendran, R. Boomishankar, R. J. Butcher, Inorg. Chem. 2001, 40, 940-945.

[51] V. Chandrasekhar, S. Nagendran, S. Kingsley, V. Krishnan, R. Boomishankar, R. J. Butcher, Proc. Indian Acad. Sci. (Chem. Sci.) 2000, 112, 171-178.

[52] V. Chandrasekhar, S. Nagendran, R. J. Butcher, Organometallics 1999, 18, 44884492.

[53] M. G. Voronkov, E. A. Maletina, V. K. Roman, Heterosiloxanes, (Soviet Scientific Review Supplement, Series Chemistry, Vol. 1), Academic Press, London 1988.

[54] Tailor-Made Silicon-Oxygen Compounds: From Molecules to Materials, R. Corriu, P. Jutzi, (Eds.), Vieweg: Braunschweig, 1996.

[55] L. King, A. C. Sullivan, Coord. Chem. Rev. 1999, 189, 19-57.

[56] J. Beckmann, K. Jurkschat, Coord. Chem. Rev. 2001, 215, 267-300.

[57] V. Lorenz, A. Fischer, S. Giessmann, J. W. Gilje, Y. Gun'ko, K. Jacob, F. T. Edelmann, Coord. Chem. Rev. 2000, 206-207, 321-368.

[58] R. Murugavel, A. Voigt, M. G. Walawalkar, H. W. Roesky, Chem. Rev. 1996, 96, 2205-2236.

[59] F. A. Cotton, G. Wilkinson, C. A. Murillo, M. Bochmann, Advanced Inorganic Chemistry, $5^{\text {th }}$ ed.; Join Wiley and Sons: New York, 1999.

[60] (a) R. Duchateau, Chem. Rev. 2002, 102, 3525-3542. (b) F. J. Feher, T. A. Budzichowski, Polyhedron 1995, 14, 3239-3253. (c) H. C. L. Abbenhuis, Chem. Eur. $J .2000,6,25-32$.

[61] (a) K. W. Terry, T. D. Tilley, Chem. Mater. 1991, 3, 1001-1003. (b) K. W. Terry, P. K. Ganzel, T. D. Tilley, Chem. Mater. 1992, 4, 1290-1295. 
[62] K. W. Terry, C. G. Lugmair, P. K. Gantzel, T. D. Tilley, Chem. Mater. 1996, 8, 274280.

[63] N. Maxim, A. Overweg, P. J. Kooyman, J. H. M. C. van Wolput, R. W. J. M. Hanssen, R. A. van Santen, H. C. L. Abbenhuis, J. Phys. Chem. 2002, 106, 22032209. (b) R. W. J. M. Hanssen, A. Meetsma, R. A. van Santen, H. C. L. Abbenhuis, Inorg. Chem. 2001, 40, 4049-4052. (c) Z. Fei, S. Busse, F. T. Edelmann, J. Chem. Soc., Dalton Trans. 2002, 2587-2589.

[64] R. Murugavel, V. Chandrasekhar, H. W. Roesky, Acc. Chem. Res. 1996, 29, 183-189.

[65] R. Murugavel, A. Voigt, M. G. Walawalkar, H. W. Roesky, Organosilicon Chemistry III: From Molecules to Materials, N. Auner, J. Weis, (Eds.), Wiley-VCH Verlag GmbH, Weinheim, 1998, 376-394.

[66] R. Murugavel, M. Bhattacharjee, H. W. Roesky, Appl. Organomet. Chem. 1999, 13, 227-243.

[67] H. W. Roesky, G Anantharaman, V. Chandrasekhar, V. Jancik, S. Singh, Chem. Eur. J. 2004, 10, 4106-4114.

[68] (a) H. N. Stokes, Chem. Ber. 1891, 24, 933-942. (b) A. Labenburg, Chem. Ber. 1871, 4, 91-94.

[69] (a) H. Schmidbaur, Angew. Chem. 1965, 77, 206-216; Angew. Chem. Int. Ed. Engl. 1965, 4, 201. (b) F. Schindler, H. Schmidbaur, Angew. Chem. 1967, 79, 697-732; Angew. Chem. Int. Ed. Engl. 1967, 6, 683-694.

[70] (a) M. Veith, O. Schütt, J. Blin, S. Becker, J. Freres, V. Huch, Z. Anorg. Allg. Chem. 2002, 628, 138-146. (b) M. Veith, M. Jarczyk, V. Huch, Angew. Chem. 1997, 109, 140-142; Angew. Chem. Int. Ed. Engl. 1997, 36, 117-119.

[71] (a) C. A. Zechmann, T. J. Boyle, M. A. Rodriguez, R. A. Kemp, Inorg. Chim. Acta. 2001, 319, 137-146. (b) R. Fandos, A. Otero, A. Rodríguez, M. J. Ruiz, P. Terreros, Angew. Chem. 2001, 113, 2968-2971; Angew. Chem. Int. Ed. 2001, 40, 2884-2887. 
[72] (a) R. Murugavel, M. G. Walawalkar, G. Prabusankar, P. Davis, Organometallics 2001, 20, 2639-2642. (b) G. Prabusankar, R. Murugavel, R. J. Butcher, Organometallics 2005, 24, 2124-2128.

[73] M. Veith, M. Jarczyk, H. Vogelgesang, Organometallics 2002, 21, 380-388.

[74] F. J. Feher, S. L. Gonzales, J. W. Ziller, Inorg. Chem. 1988, 27, 3440-3442.

[75] F. J. Feher, J. Am. Chem. Soc. 1986, 108, 3850-3852.

[76] N. Winkhofer, H. W. Roesky, M. Noltemeyer, W. T. Robinson, Angew. Chem. 1992, 104, 670-671; Angew. Chem. Int. Ed. Engl. 1992, 31, 599-601.

[77] (a) M. L. Montero, A. Voigt, M. Teichert, I. Usón, H. W. Roesky, Angew. Chem. 1995, 107, 2761-2763; Angew. Chem. Int. Ed. Engl. 1995, 34, 2504-2506. (b) A. Voigt, R. Murugavel, E. Parisini, H. W. Roesky, Angew. Chem. 1996, 108, 823-825; Angew. Chem., Int. Ed. Engl. 1996, 35, 748-750. (c) A. Voigt, M. G. Walawalkar, R. Murugavel, H. W. Roesky, E. Parisini, P. Lubini, Angew. Chem. 1997, 109, 23132315; Angew. Chem., Int. Ed. Engl. 1997, 36, 2203-2205.

[78] U. Ritter, N. Winkhofer, R. Murugavel, A. Voigt, D. Stalke, H. W. Roesky, J. Am. Chem. Soc. 1996, 118, 8580-8587.

[79] (a) N. Winkhofer, A. Voigt, H. Dorn, H. W. Roesky, A. Steiner, D. Stalke, A. Reller, Angew. Chem. 1994, 106, 1414-1416; Angew. Chem. Int. Ed. Engl. 1994, 33, 13521354. (b) R. Murugavel, V. Chandrasekhar, A. Voigt, H. W. Roesky, H. -G. Schmidt, M. Noltemeyer, Organometallics, 1995, 14, 5298-5301.

[80] A. I. Gouzyr, H. Wessel, C. E. Barnes, H. W. Roesky, M. Teichert, I. Usón, Inorg. Chem. 1997, 36, 3392-3393.

[81] (a) A. Voigt, R. Murugavel, H. W. Roesky, Organometallics 1996, 15, 5097-5101. (b) A. Voigt, R. Murugavel, V. Chandrasekhar, N. Winkhofer, H. W. Roesky, H.-G. Schmidt, I. Usón, Organometallics 1996, 15, 1610-1613. (c) V. Chandrasekhar, R. 
Murugavel, A. Voigt, H. W. Roesky, H. -G. Schmidt, M. Noltemeyer, Organometallics 1996, 15, 918-922.

[82] G. Anantharaman, N. D. Reddy, H. W. Roesky, J. Magull, Organometallics 2001, 20, $5777-5779$.

[83] G. Anantharaman, H. W. Roesky, J. Magull, Angew. Chem. 2002, 114, 1274-1277; Angew. Chem. Int. Ed. 2002, 41, 1226-1229.

[84] G. Anantharaman, H. W. Roesky, H.-G. Schmidt, M. Noltemeyer, J. Pinkas, Inorg. Chem. 2003, 42, 970-973.

[85] G. Anantharaman, V. Chandrasekhar, U. N. Nehete, H. W. Roesky, D. Vidovic, J. Magull, Organometallics 2004, 23, 2251-2256.

[86] M. Fujiwara, H. Wessel, H.-S. Park, H. W. Roesky, Tetrahedron, 2002, 58, 239-243.

[87] M. Fujiwara, H. Wessel, H.-S. Park, H. W. Roesky, Chem. Mater. 2002, 14, 49754981.

[88] H. Puff, M. P. Böckmann, T. R. Kök, W. Schuh, J. Organomet. Chem. 1984, 268, 197-206.

[89] A. Mazzah, A. Haoudi-Mazzah, M. Noltemeyer, H. W. Roesky, Z. Anorg. Allg. Chem. 1991, 604, 93-103.

[90] M. Akkurt, T. R. Kök, P. Faleschini, L. Randaccio, H. Puff, W. Schuh, J. Organomet. Chem. 1994, 470, 59-66.

[91] H. Puff, T. R. Kök, P. Nauroth, W. Schuh, J. Organomet. Chem. 1985, 281, 141-148.

[92] J. Beckmann, K. Jurkschat, N. Pieper, M. Schürmann, Chem. Commun. 1999, 10951096.

[93] (a) F. J. Feher, K. J. Weller, J. J. Schwab, Organometallics, 1995, 14, 2009-2017. (b) J. N. Greeley, L. M. Meeuwenberg, M. M. Banaszak Holl, J. Am. Chem. Soc. 1998, 120, 7776-7782. (c) M. A. Said, H. W. Roesky, C. Rennekamp, M. Andruh, H. -G. 
Schmidt, M. Noltemeyer, Angew. Chem.1999, 111, 702-705; Angew. Chem. Int. Ed. 1999, 38, 661-664.

[94] M. F. Lappert, S. J. Miles, J. L. Atwood, M. J. Zaworotko, A. J. Carty, J. Organomet. Chem. 1981, 212, C4-C6.

[95] M. J. S. Gynane, D. H. Harris, M. F. Lappert, P. P. Power, P. Rivière, M. RivièreBaudet, J. Chem. Soc. Dalton Trans. 1977, 2004-2009.

[96] F. Riedmiller, G. L. Wegner, A. Jockisch, H. Schmidbaur, Organometallics 1999, 18, 4317-4324.

[97] C. Brelière, F. Carré, R. J. P. Corriu, G. Royo, Organometallics 1988, 7, 1006-1008.

[98] A. Castel, P. Riviere, J. Satgé, H. Y. Ko, Organometallics 1990, 9, 205-210.

[99] H. W. Roesky, Solid State Sci. 2001, 3, 777-782.

[100] M. Veith, Chem. Ber. 1978, 111, 2536-2546.

[101] P. Kircher, G. Huttner, L. Zsolnai, A. Driess, Angew. Chem. 1998, 110, 1756-1758; Angew. Chem. Int. Ed. Engl. 1998, 37, 1666-1668.

[102] P. G. Harrison, B. J. Haylett, T. J. King, J. Chem. Soc. Chem. Commun. 1978, 112113.

[103] T. J. Boyle, T. M. Alam, M. A. Rodriguez, C. A. Zechmann, Inorg. Chem. 2002, 41, $2574-2582$.

[104] W. -W. du Mont, M. Grenz, Z. Naturforsch. B 1983, 38, 113-114.

[105] M. J. McGeary, R. H. Cayton, K. Folting, J. C. Huffman, K. G. Caulton, Polyhedron, 1992, $11,1369-1382$.

[106] M. Veith, C. Mathur, V. Huch, J. Chem. Soc. Dalton Trans. 1997, 995-999.

[107] C. Eaborn, P. B. Hitchcock, J. D. Smith, S. E. Sözerli, Organometallics 1997, 16, $5653-5658$.

[108] G. M. de Lima, D. J. Duncalf, Main Group Met. Chem. 2000, 23, 395-400. 
[109] L. R. Sita, R. M. Xi, G. P. A. Yap, L. M. Liable-Sands, A. L. Rheingold, J. Am. Chem. Soc. 1997, 119, 756-760.

[110] (a) J. Beckmann, K. Jurkschat, Coord. Chem. Rev. 2001, 215, 267-300. (b) J. Beckmann, K. Jurkschat, D. Müller, S. Rabe, M. Schürmann, Organometallics 1999, 18, 2326-2330. (c) J. Beckmann, B. Mahieu, W. Nigge, D. Schollmeyer, M. Schürmann, K. Jurkschat, Organometallics 1998, 17, 5697-5712. (d) J. Beckmann, K. Jurkschat, B. Mahieu, M. Schürmann, Main Group Met. Chem. 1998, 21, 113-122. (e) M. Veith, S. Mathur, V. Huch, J. Chem. Soc. Dalton Trans. 1996, 2485-2490.

[111] R. Murugavel, P. Böttcher, A. Voigt, M. G. Walawalkar, H. W. Roesky, E. Parisini, M. Teichert, M. Noltemeyer, Chem. Commun. 1996, 2417-2418.

[112] U. N. Nehete, V. Chandrasekhar, G. Anantharaman, H. W. Roesky, D. Vidovic, J. Magull, Angew. Chem. 2004, 116, 3930-3932; Angew. Chem., Int. Ed. 2004, 43, 38423844.

[113] C. Gaffney, P. G. Harrison, T. J. King, Chem. Commun. 1980, 1251-1252.

[114] K. W. Terry, K. Su, T. D. Tilley, A. L. Rheingold, Polyhedron 1998, 17, 891-897.

[115] C. S. Weinert, I. A. Guzei, A. L. Rheingold L. R. Sita, Organometallics 1998, 17, 498-500.

[116] W. W. du Mont, M. Grenz, Chem. Ber. 1981, 114, 1180-1181.

[117] H. Schmidbaur, M. Bergfeld, Z. Anorg. Allg. Chem. 1968, 363, 84-88.

[118] W. Patnode, F. C. Schmidt, J. Am. Chem. Soc. 1945, 67, 2272-2273.

[119] V. Lorenz, A. Fischer, S. Gießmann, J. W. Gilje, Y. Gun'ko, K. Jacob, F. T. Edelmann, Coord. Chem. Rev. 2001, 206, 321-368.

[120] S. N. Borisov, M. G. Voronkov, E.Y. Lukevits, Organosilicon Heteropolymers and Hetero Compounds; Plenum: New York, 1970. 
[121] (a) M. Baier, K. Angermaier, H. Schmidbaur, Z. Naturforsch. B 1994, 49, 855-858.

(b) M. Baier, P. Bissinger, J. Blümel, H. Schmidbaur, Chem. Ber. 1993, 126, 947-950.

(c) F. A. Henglein, R. Lang, K. Scheinost, Makromol. Chem. 1956, 18, 102-118.

[122] (a) M. C. Massiani, R. Papiernik, L. G. Hubert-Pfalzgraf, J. C. Daran, Polyhedron 1991, 10, 437-445. (b) M. Mehring, M. Schürmann, Chem. Commun. 2001, 23542355. (c) K. H. Whitmire, S. Hoppe, O. Sydora, J. L. Jolas, C. M. Jones, Inorg. Chem. 2000, 39, 85-97. (d) D. Mansfeld, M. Mehring, M. Schürmann, Angew. Chem. 2005, 117, 250-254; Angew. Chem., Int. Ed. 2005, 44, 245-249.

[123] (a) F. J. Feher, T. A. Budzichowski, Organometallics 1991, 10, 812-815. (b) F. J. Feher, T. A. Budzichowski, K. Rahimian, J. W. Ziller, J. Am. Chem. Soc. 1992, 114, 3859-3866.

[124] (a) T. Möller, R. Harjula, A. Paajanen. Sep. Sci. Technol. 2003, 38, 2995-3007. (b) T. Möller, R. Harjula, M. Pillinger, A. Dyer, J. Newton, E. Tusa, S. Amin, M. Webb, A. Araya, J. Mater. Chem., 2001, 11, 1526-1532.

[125] P. S. Anand, D. R. Baxi, Ind. J. Technol. 1978, 16, 211-212.

[126] V. Ghoulipour, S. W. Husain, Anal. Sci. 2000, 16, 1079-1081.

[127] J. Minelly, A. Ellison, Optical Fiber Technology, 2002, 8, 123-138.

[128] J. H. Kim, T. Tsurumi, T. Kamiya, M. Daimon, J. Appl. Phys. 1994, 75, 2924-2928.

[129] K. Moedritzer, Inorg. Chem. 1964, 3, 609-610.

[130] W. Clegg, N. A. Compton, R. J. Errington, G. A. Fisher, M. E. Green, D. C. R. Hockless, N. C. Norman, Inorg. Chem. 1991, 30, 4680-4682.

[131] A. F. Holleman, E. Wiberg, Lehrbuch der Anorganischen Chemie, 81.-90. ed., Walter de Gruyter Berlin, New York, 1976.

[132] (a) A. A. Ivanov, V. S. Chernyavsky, M. J. Gross, A. S. Kharitonov, A. K. Uriarte, G. I. Panov, Appl. Catal. A: Gen. 2003, 249, 327-343. (b) D. P. Ivanov, V. I. Sobolev, L. V. Pirutko, G. I. Panov, Adv. Synth. Catal. 2002, 344, 986-995. (c) D. P. Ivanov, M. 
A. Rodkin, K. A. Dubkov, A. S. Kharitonov, G. I. Panov, Kinet. and Catal. 2000, 41, $771-775$

[133] (a) V. R. Choudhary, S. K. Jana, A. S. Mamman, Microporous Mesoporous Mater. 2002, 56, 65-71. (b) V. R. Choudhary, S. K. Jana, J. Mol. Catal. A: Chem. 2002, 180, 267-276.

[134] V. R. Choudhary, K. Mantri, S. K. Jana, Microporous Mesoporous Mater. 2001, 47, 179-183.

[135] (a) H. Schmidbaur, M. Schmidt, J. Am. Chem. Soc. 1962, 84, 3600-3601. (b) A. N. Kornev, T. A. Chesnokova, V. V. Semenov, E. V. Zhezlova, L. N. Zakharov, L. G. Klapshina, G. A. Domrachev, V. S. Rusakov, J. Organomet. Chem. 1997, 547, $113-$ 119. (c) C. Nozaki, C. G. Lugmair, A. T. Bell, T. D. Tilley, J. Am. Chem. Soc. 2002, 124, 13194-13203. (d) T. A. Chesnokova, E. V. Zhezlova, A. N. Kornev, Y. V. Fedotova, L. N. Zakharov, G. K. Fukin, Y. A. Kursky, T. G. Mushtina, G. A. Domrachev, J. Organomet. Chem. 2002, 642, 20-31.

[136] (a) F. C. Liu, K. D. John, B. L. Scott, R. T. Baker, K. C. Ott, W. Tumas, Angew. Chem. 2000, 112, 3257-3260; Angew. Chem. Int. Ed. 2000, 39, 3127-3130. (b) P. A. Shapley, W. S. Bigham, M. T. Hay, Inorg. Chim. Acta. 2003, 345, 255-260. (c) M. T. Hay, B. J. Hainaut, S. J. Geib, Inorg. Chem. Commun. 2003, 6, 431-434.

[137] E. C. Alyea, D. C. Bradley, R. G. Copperthwaite, J. Chem. Soc. Dalton Trans. 1972, $1580-1584$

[138] (a) R. Pearce, W. R. Patterson, Catalysis and Chemical Processes; Blackie and Son: Glasgow, 1981. (b) T. Seiyama, K. Tanabe, New Horizons in Catalysis; Elsevier: Amsterdam, 1980. (c) Y. Iwasawa, Tailored Metal Catalysts; Reidel: Dordrecht, 1986. (d) C. L. Thomas, Catalytic Processes and Proven Catalysts; Academic Press: New York, 1970. (e) W. Kaminsky, H. Sinn, Transition Metals and Organometallics as Catalysts for Olefin Polymerization; Springer-Verlag: Heidelberg, 1988. 
[139] T. Sun, M. D. Fokema, J. Y. Ting, Catal. Today 1997, 33, 251-261.

[140] F. T. Edelmann. Angew. Chem. 1992, 104, 600-601; Angew. Chem., Int. Ed. 1992, 31, 586-587.

[141] (a) R. Murugavel, V. S. Shete, K. Baheti, P. Davis, J. Organomet. Chem. 2001, 625, 195-199. (b) R. Murugavel, P. Davis, V. S. Shete, Inorg. Chem. 2003, 42, 4696-4706.

[142] U. N. Nehete, G. Anantharaman, V. Chandrasekhar, R. Murugavel, M. G. Walawalker, H. W. Roesky, D. Vidovic, J. Magull, K. Samwer, B. Sass, Angew. Chem. 2004, 116, 3920-3923; Angew. Chem., Int. Ed. 2004, 43, 3832-3835.

[143] (a) M. M. Olmstead, G. A. Sigel, H. Hope, X. Xu, P. P. Power, J. Am. Chem. Soc. 1985, 107, 8087-8091. (b) G. A. Sigel, R. A. Bartlett, D. Decker, M. M. Olmstead, P. P. Power, Inorg. Chem. 1987, 26, 1773-1780. (c) I. Abrahams, M. Lazell, M. Motevalli, C. Simon. A. C. Sullivan, Chem. Hetero. Compnd. 1999, 35, 954-964. (d) H. Ackermann, F. Weller, K. Dehnicke, Z. Naturforsch. B 2000, 55, 448-451. (e) S. Yoshimitsu, S. Hikichi, M. Akita, Organometallics 2002, 21, 3762-3773. (f) I. Abrahams, M. Motevalli. D. Shah, A. C. Sullivan, P. Thornton, Chem. Commun. 1993, 1514-1515. (g) M. B. Hursthouse, M. A. Mazid, M. Motevalli. M. Sanganee, A. C. Sullivan, J. Organomet. Chem. 1990, 381, C43-C46. (h) B. Becker, K. Radacki, A. Konitz, W. Wojnowski, Z. Anorg. Allg. Chem. 1995, 621, 904-908.

[144] V. Esposito, E. Solari, C. Floriani, Inorg. Chem. 2000, 39, 2604-2613.

[145] A. Voigt, R. Murugavel, M. L. Montero, H. Wessel, F. Liu, H. W. Roesky, I. Usón, T. Albers, E. Parisini, Angew. Chem. 1997, 109, 1020-1022; Angew. Chem., Int. Ed. Engl. 1997, 36, 1001-1003.

[146] (a) R. A. Andersen, K. Jr. Faegri, J. C. Green, A. Haaland, M. F. Lappert, W. Leung, K. Rypdal, Inorg. Chem. 1988, 27, 1782-1786. (b) H. Bürger, U. Wannagat, Monatsh. Chem. 1963, 94, 1007-1012.

[147] M. M. Olmstead, P. P. Power, S. C. Shoner, Inorg. Chem. 1991, 30, 2547-2551. 
[148] D. F. Shriver, M. A. Drezdzon, The Manipulation of Air-Sensitive Compounds, $2^{\text {nd }}$ ed., McGraw-Hill, New York, 1969.

[149] D. D. Perrin, W. L. F. Armarego, Purification of Laboratory Chemicals, $3^{\text {rd }}$ ed., Pergamon, London, 1988.

[150] G. M. Sheldrick, SHELXTL-PLUS, Siemens X-ray Instruments, Madison, 1990.

[151] G. M. Sheldrick, SHELXS-97, Program for Structure Solution, Acta Crystallogr. Sect. A 1990, 46, 467-473.

[152] G. M. Sheldrick, SHELXL-97, Program for Structure Refinement, Universität Göttingen, 1997. 


\section{Lebenslauf}

$\begin{array}{lcl}\text { Name } & : & \text { Umesh Namdeo Nehete } \\ \text { Geburtsort } & : & \text { Jalgaon } \\ \text { Geburtsdatum } & : & 18.03 .1975 \\ \text { Eltern } & : & \text { Namdeo Puna Nehete (Vater) } \\ & : & \text { Leela Namdeo Nehete (Mutter) } \\ \text { Familienstand } & : & \text { Ledig } \\ \text { Staatsangehörigkeit : } & \text { Indisch }\end{array}$

\section{Schulausbildung}

$\begin{array}{ll}1980-1985 & \begin{array}{l}\text { T. S. Zope Vidyalaya, Bhusawal, Indien } \\ \text { (Grundschule, Classes I - IV) }\end{array} \\ 1985-1991 & \begin{array}{l}\text { K. Narkhede Vidyalaya, Bhusawal, Indien } \\ \text { (Gymnasium, Classes VI - X) }\end{array} \\ 1991-1993 & \begin{array}{l}\text { P. O. Nahata College, Bhusawal, Indien } \\ \text { (Gymnasium, Classes XI - XII) }\end{array}\end{array}$

\section{Hochschulausbildung}

$1994-1998$

März 1999

$1998-2000$

März 2001

$2000-2003$

September 2004

April 2003 -

Dezember 2005
North Maharashtra University, Jalgaon, Indien

Bachelor of Science (Zwischenprüfung, Hauptfach: Chemie)

North Maharashtra University, Jalgaon, Indien Master of Science (Abschußprüfung, Fach: Organische Chemie)

Project Assistant, National Chemical Laboratory, Pune

Äquivalenzprüfung zum Diplomexamen - Fach Chemie, Universität Göttingen

Anfertigung der Dissertation unter Anleitung von

Prof. Dr. Dr. h.c. mult. H. W. Roesky am Institut für Anorganische Chemie der Georg-August-Universität Göttingen 


\section{List of Publications}

[1] New Polyhedral Zinc Siloxanes: Synthesis and X-ray Crystal Structures of $\mathrm{Zn}_{8} \mathrm{Me}_{7}(\text { dioxane })_{2}\left(\mathrm{O}_{3} \mathrm{SiR}\right)_{3} \quad$ and $\quad\left[\mathrm{Zn}_{7} \mathrm{Me}_{2}(\mathrm{THF})_{5}\left(\mathrm{O}_{3} \mathrm{SiR}\right)_{4}\right] \quad[\mathrm{R}=(2,6-$ $\left.\left.i \mathrm{Pr}_{2} \mathrm{C}_{6} \mathrm{H}_{3}\right) \mathrm{N}\left(\mathrm{SiMe}_{3}\right)\right]$.

Ganapathi Anantharaman, Vadapalli Chandrasekhar, Umesh N. Nehete, Herbert W. Roesky, Denis Vidovic, Jörg Magull Organometallics, 2004, 23, 2251-2256.

[2] Polyhedral Ferrous and Ferric Siloxanes.

Umesh N. Nehete, Ganapathi Anantharaman, Vadapalli Chandrasekhar, Ramaswamy Murugavel, Mrinalini G. Walawalkar, Herbert W. Roesky, Denis Vidovic, Jörg Magull, Konrad Samwer, Björn Sass Angew. Chem. 2004, 116, 3920-3923; Angew. Chem., Int. Ed. 2004, 43, 3832-3835.

[3] Molecular $(\mathrm{SnO})_{6}$ Trapped by Two $\mathrm{R}_{2} \mathrm{Si}_{2} \mathrm{O}_{3}$ Fragments : X-Ray Single-Crystal Structure of $\left[(\mathrm{SnO})_{6}\left(\mathrm{R}_{2} \mathrm{Si}_{2} \mathrm{O}_{3}\right)_{2}\right]\left[\mathrm{R}=\left(2,6-i \mathrm{Pr}_{2} \mathrm{C}_{6} \mathrm{H}_{3}\right) \mathrm{N}\left(\mathrm{SiMe}_{3}\right)\right]$

Umesh N. Nehete, Vadapalli Chandrasekhar, Ganapathi Anantharaman, Herbert W. Roesky, Denis Vidovic, Jörg Magull Angew. Chem. 2004, 116, 3930-3932; Angew. Chem., Int. Ed. 2004, 43, 3842-3844.

[4] Heavy Metal Containing Polyhedral Metallasiloxane Derived from an Aminosilanetriol: Synthesis and Structural Characterization of $\left[(\mathrm{PbO})_{6}\left(\mathrm{R}_{2} \mathrm{Si}_{2} \mathrm{O}_{3}\right)_{2}\right]$ $\left[\mathrm{R}=\left(2,6-i \mathrm{Pr}_{2} \mathrm{C}_{6} \mathrm{H}_{3}\right) \mathrm{N}\left(\mathrm{SiMe}_{3}\right)\right]$

Umesh N. Nehete, Vadapalli Chandrasekhar, Vojtech Jancik, Herbert W. Roesky, Regine Herbst-Irmer Organometallics, 2004, 23, 5372-5374.

[5] The Formal Conversion of a Proton to Hydride Using Si-OH Group and Ge(II) Species Leads to the Formation of the Germanium(IV) Hydride Cluster $\left[\left(\mathrm{RSiO}_{3} \mathrm{GeH}\right)_{4}\right]$ Umesh N. Nehete, Vadapalli Chandrasekhar, Herbert W. Roesky, Jörg Magull Angew. Chem. 2005, 117, 285-288; Angew. Chem., Int. Ed. 2005, 44, 281-284.

[6] Synthesis and Chemical Properties of Tetraalkyl Substituted Thiourea Adducts with Chlorine

Herbert W. Roesky, Umesh N. Nehete, Sanjay Singh, Hans-Georg Schmidt, Yuiry G. Shermolovich Main Group Chem. 2005, 4, 11-21. 
[7] A Rearrangement of Azobenzene by Interaction with an Aluminum(I) Monomer LA1 $\left(\mathrm{L}=\mathrm{HC}[(\mathrm{CMe})(\mathrm{NAr})]_{2}, \mathrm{Ar}=2,6-i \mathrm{Pr}_{2} \mathrm{C}_{6} \mathrm{H}_{3}\right)$

Hongping Zhu, Jianfang Chai, Hongjun Fan, Herbert W. Roesky, Umesh N. Nehete, Hans-Georg Schmidt, Mathias Noltemeyer Eur. J. Inorg. Chem. 2005, 11, 2147-2150.

[8] Polyhedral Cobalt(II) and Iron(II) Siloxanes: Synthesis and X-ray Crystal Structure of $\left[\left(\mathrm{RSi}(\mathrm{OH}) \mathrm{O}_{2}\right) \mathrm{Co}\left(\mathrm{OPMe}_{3}\right)\right]_{4}$ and $\left[\left(\mathrm{RSiO}_{3}\right)_{2}\left(\mathrm{RSi}(\mathrm{OH}) \mathrm{O}_{2}\right)_{4}\left(\mu_{3}-\mathrm{OH}\right)_{2} \mathrm{Fe}_{8}(\mathrm{THF})_{4}\right] \quad(\mathrm{R}=$ $\left.\left(2,6-i \mathrm{Pr}_{2} \mathrm{C}_{6} \mathrm{H}_{3}\right) \mathrm{N}\left(\mathrm{SiMe}_{3}\right)\right)$

Umesh N. Nehete, Herbert W. Roesky, Hongping Zhu, Sharanappa Nembenna, HansGeorg Schmidt, Mathias Noltemeyer, Dmitrij Bogdanov, Konrad Samwer Inorg. Chem. 2005, 44, 7243-7248.

[9] Synthesis, Spectral studies, and Structural Characterization of $\left[\mathrm{Sb}\left(\mathrm{O}_{3} \mathrm{SiR}\right)\right]_{4}$ and $\left[\mathrm{Bi}_{12}\left(\mathrm{O}_{3} \mathrm{SiR}\right)_{8}\left(\mu_{3}-\mathrm{O}\right)_{4} \mathrm{Cl}_{4}(\mathrm{THF})_{8}\right]\left(\mathrm{R}=\left(2,6-i \mathrm{Pr}_{2} \mathrm{C}_{6} \mathrm{H}_{3}\right) \mathrm{N}\left(\mathrm{SiMe}_{3}\right)\right)$

Umesh N. Nehete, Herbert W. Roesky, Vojtech Jancik, Aritra Pal, Jörg Magull Inorg. Chim. Acta 2005, article in press. 